\title{
Demography and genetic structure of an Allegheny woodrat population in northcentral West Virginia
}

\author{
Mary Elizabeth Manjerovic \\ West Virginia University
}

Follow this and additional works at: https://researchrepository.wvu.edu/etd

\section{Recommended Citation}

Manjerovic, Mary Elizabeth, "Demography and genetic structure of an Allegheny woodrat population in northcentral West Virginia" (2004). Graduate Theses, Dissertations, and Problem Reports. 2010.

https://researchrepository.wvu.edu/etd/2010

This Thesis is protected by copyright and/or related rights. It has been brought to you by the The Research Repository @ WVU with permission from the rights-holder(s). You are free to use this Thesis in any way that is permitted by the copyright and related rights legislation that applies to your use. For other uses you must obtain permission from the rights-holder(s) directly, unless additional rights are indicated by a Creative Commons license in the record and/ or on the work itself. This Thesis has been accepted for inclusion in WVU Graduate Theses, Dissertations, and Problem Reports collection by an authorized administrator of The Research Repository @ WVU. For more information, please contact researchrepository@mail.wvu.edu. 
DEMOGRAPHY AND GENETIC STRUCTURE OF AN ALLEGHENY WOODRAT POPULATION IN NORTHCENTRAL WEST VIRGINIA

MARY ELIZABETH MANJEROVIC

A Thesis Submitted to the Davis College of Agriculture, Forestry, and Consumer Sciences at West Virginia University in Partial Fulfillment of the Requirements for the Degree of

MASTER OF SCIENCE

in

Wildlife and Fisheries Resources

Division of Forestry

Petra Bohall Wood, Ph.D., Co-chair

John W. Edwards, Ph.D., Co-chair

Craig W. Stihler, M. S.

Morgantown, West Virginia

2004

Keywords: Allegheny woodrat, genetic differentiation, microsatellite, Neotoma magister, population, parentage, relatedness

Copyright 2004 Mary E. Manjerovic 


\title{
ABSTRACT \\ DEMOGRAPHY AND GENETIC STRUCTURE OF AN ALLEGHENY WOODRAT POPULATION NORTHCENTRAL WEST VIRGINIA
}

\author{
MARY ELIZABETH MANJEROVIC
}

The Allegheny woodrat (Neotoma magister) occurs throughout the Appalachian Mountains forming isolated colonies in rock outcrops, cliffs, and caves. In the past 20-30 years, populations along the northern and western peripheries of the range have experienced drastic declines. There have been suggested reasons for this decline but a lack of long-term data has prevented application of specific management actions. In recent years, there has been more insight into population structure, gene flow, and relatedness among colonies. The objectives of my study were to examine these factors at a localized level to further assist with future management decisions.

Using data collected over the last nine years, population trends were examined at three study areas in northcentral West Virginia along the western ridge of the central Appalachian Mountains. Relations to temperature and precipitation along with mast production were analyzed to determine if environmental variables are a factor impacting the population. Results suggest that there has been a decrease in the overall population with the adult female segment most affected. Juvenile capture rate was negatively correlated with winter temperature supporting the hypothesis that the severity of winters is a factor affecting the northern populations.

Geographic genetic variation was previously examined throughout the entire Allegheny woodrat distribution. The current research analyzed genetic differentiation at a smaller scale to determine if analysis of a larger proportion of the population would result in further population structure. Movements within and among specific outcrops suggest that outcrops function as breeding assemblages but that the Cheat River does not limit movement between the study areas. Results suggest that the regional populations are less differentiated than previously assumed and management decisions should be applied to a wider spatial scale to increase the genetic variation among the subpopulations. To assign parentage and kinship, likelihood based approaches were used. Results support field observations of one to four young per litter and greater juvenile dispersal in male woodrats. 


\section{ACKNOWLEDGMENTS}

Funding for this study was provided by the West Virginia Division of Natural Resources, USGS Cooperative Research Units, West Virginia Cooperative Fish and Wildlife Research Unit, and the Division of Forestry, West Virginia University. Clarion University of Pennsylvania provided use of laboratory equipment and genetic software analysis systems.

I wish to thank Dr. Petra Bohall Wood for her constant guidance while serving as my major professor. I am also grateful to Dr. John Edwards and Craig Stihler for their assistance while serving on my committee. I am indebted to Roger and Susie McPherson for their friendship and for adopting me as a second daughter.

I would like to thank multiple people for contributing data: Ryan Myers and Jon Zuck for their woodrat trapping records, Steven Castleberry for 1999 genetic data, Tim King and Shannon Julian for woodrat primers and protocol information, Bob Driscoll and John Brooks for weather data, and Jim Pack for regional mast records. I am also grateful for George Seidel for all of his statistical assistance.

I give special thanks to Dr. Frank Ammer for not only helping me through the genetic data collection but for the analysis and interpretation as well. I also am eternally grateful to all of the undergraduate and graduate help in the field, including Jon Simmons, Joe Rogerson, Michael Dye, Matt Schnupp, Tasha Davies, Tamara Terry, Elizabeth Osier, Jason Freund, Scott Bosworth, Cindy Sanders, Aaron Proctor, and Joe Osbourne.

Lastly, I would like to thank all of my friends and family. Without their constant support, none of this would have been possible. Most especially, I thank my mother and father, who were always there for me and who may never realize just how much they helped me throughout this entire process. 


\section{TABLE OF CONTENTS}

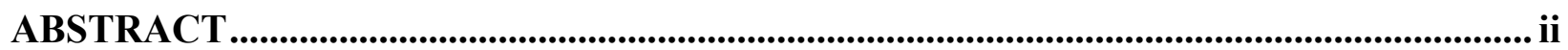

ACKNOWLEDGMENTS ................................................................................................ii

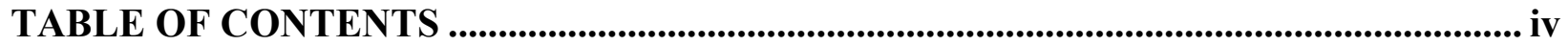

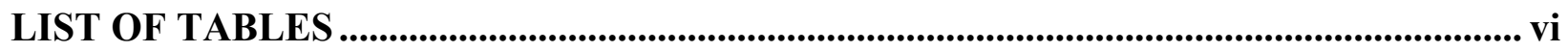

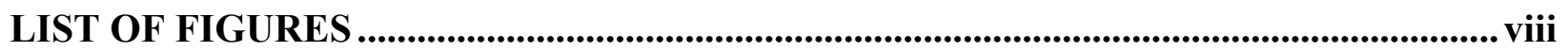

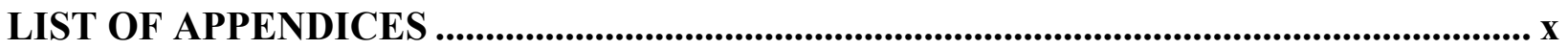

CHAPTER 1. INTRODUCTION AND LITERATURE REVIEW ............................................ 1

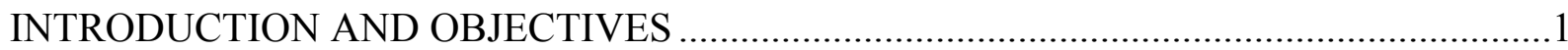

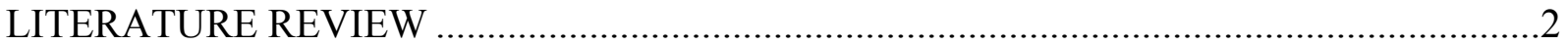

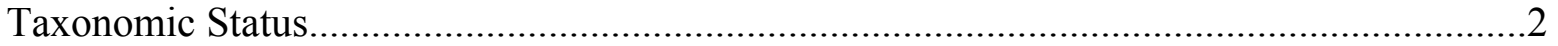

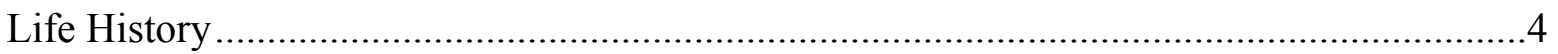

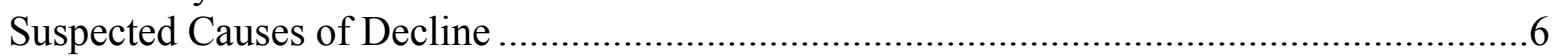

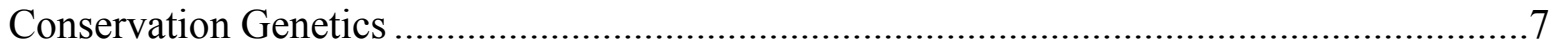

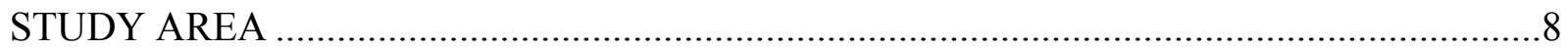

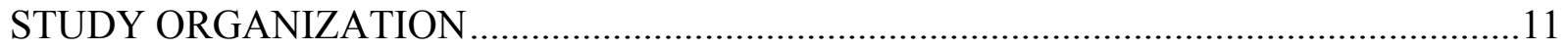

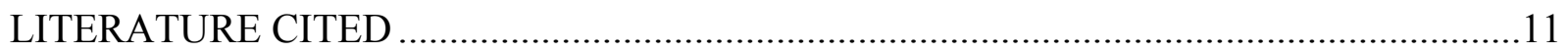

CHAPTER 2. ALLEGHENY WOODRAT POPULATION TRENDS IN

NORTHCENTRAL WEST VIRGINIA _.............................................................................. 16

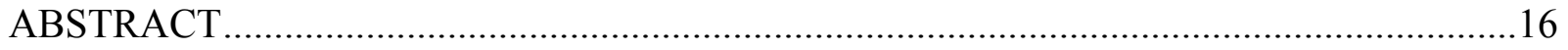

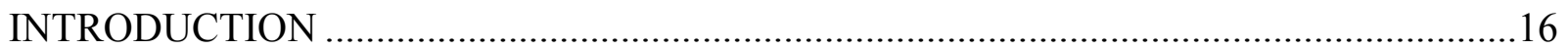

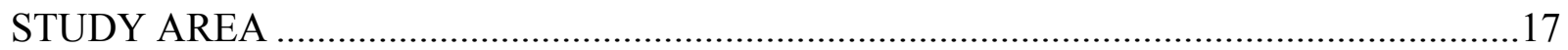

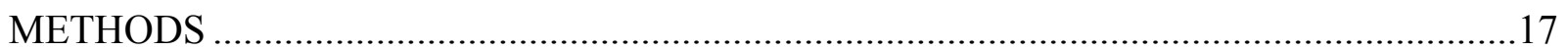

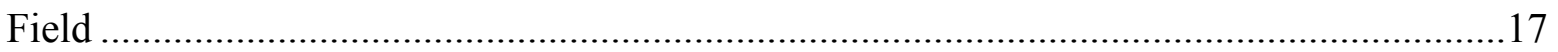

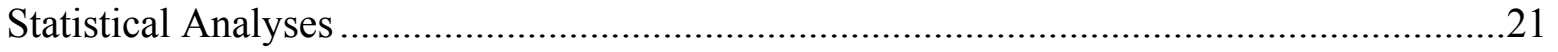

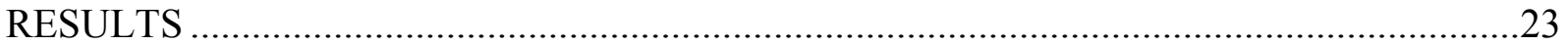

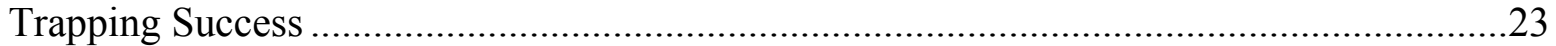

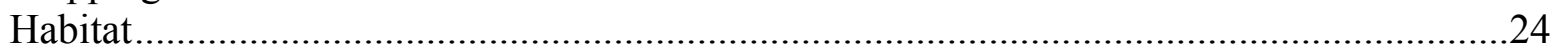

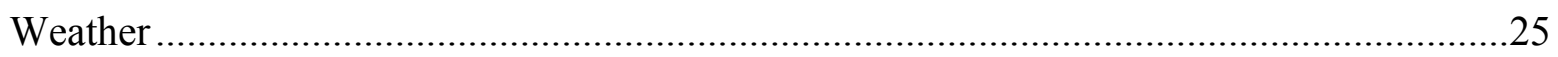

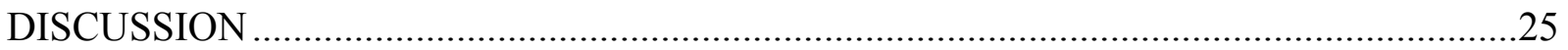

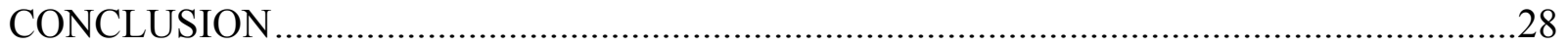

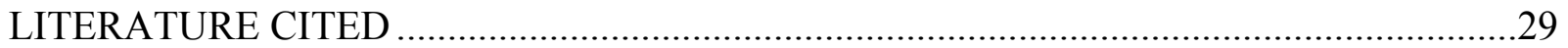




\section{CHAPTER 3. GENETIC STRUCTURE AND PARENTAGE ANALYSIS OF AN}

ALLEGHENY WOODRAT POPULATION ........................................................................ 49

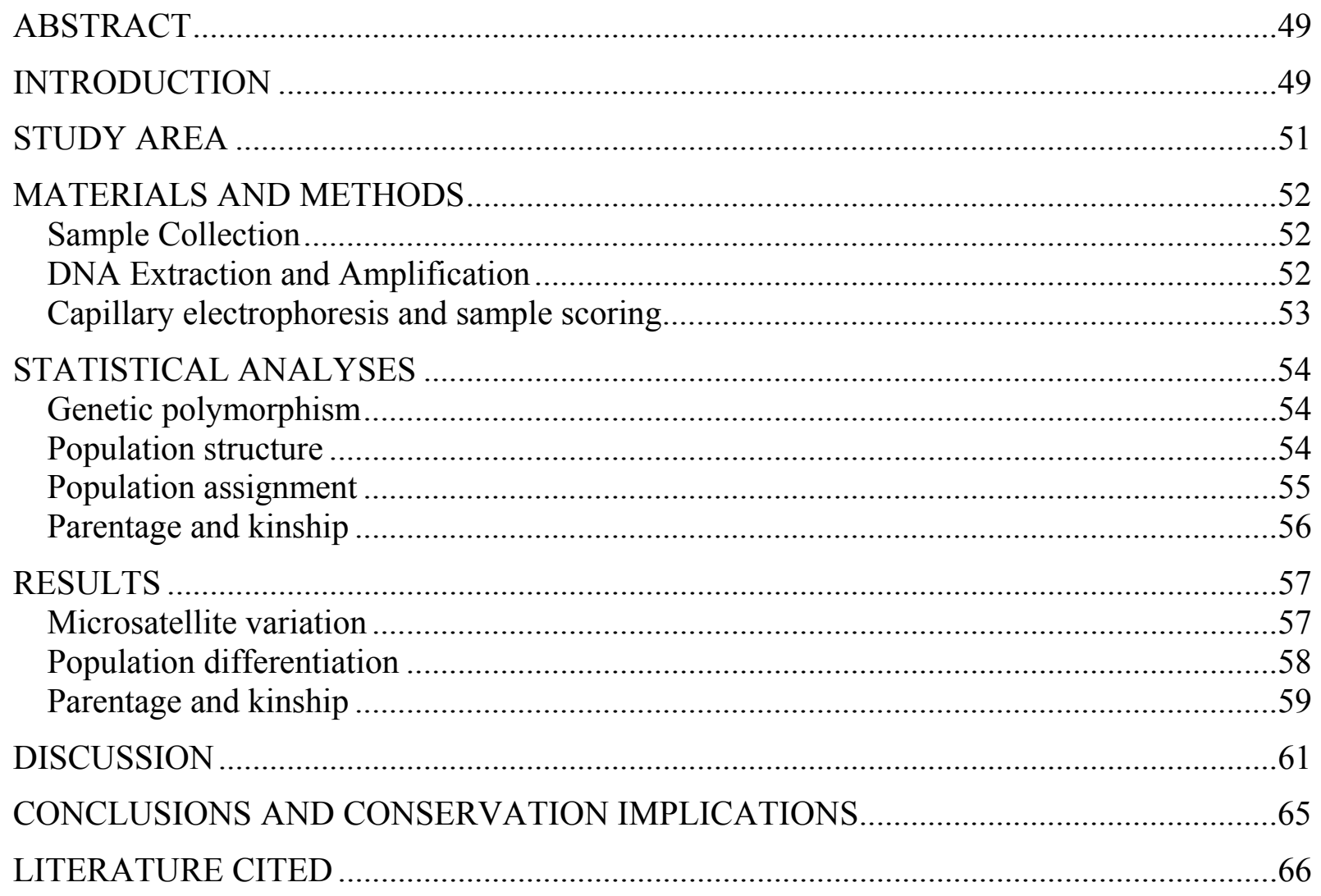




\section{LIST OF TABLES}

\section{CHAPTER 2.}

Table 1. Vegetative characteristics modified from James and Shugart (1970) and measured at Coopers Rock State Forest, West Virginia and Snake Hill Wildlife Management Area, West Virginia during summer 2002.

Table 2. Number of individual Allegheny woodrats captured each year $(n)$ adjusted per 100 trap night (CPUE) and the percent of total captures for that given year at Coopers Rock State Forest (CR), West Virginia University Research Forest (UF), and Snake Hill Wildlife Management Area (SH) in West Virginia.

Table 3. Number of individual Allegheny woodrats captured each year (n) and number and percentage of those captures that were recaptures from previous years at Coopers Rock State Forest (CR), West Virginia University Research Forest (UF), and Snake Hill Wildlife Management Area (SH) in West Virginia.

Table 4. ANOVA results for adult male, adult female, juvenile captures and all captures combined from all three study areas between 1995-2003.

Table 5. ANOVA results for adult male, adult female, juvenile captures and all captures combined from specific sites trapped $>4$ years at SH and CR between 1999-2003.

Table 6. ANOVA results for adult male, adult female, juvenile captures and all captures combined from 13 specific rock outcrops trapped $>4$ years at SH and CR between 19992003

Table 7. Average vegetative characteristics measured at 68 plots within Coopers Rock State Forest, West Virginia and 21 plots at Snake Hill Wildlife Management Area, West Virginia in August 2002

Table 8. Pearson correlation coefficients for seasonal weather variables. Results were considered significant at $P<0.05$.

\section{CHAPTER 3.}

Table 1. Published sequences, reported repeat motif, number of published and observed alleles (A), published and observed size in base pairs (bp), and annealing temperature (AT) of forward and reverse primers for microsatellite loci (Castleberry et al. 2002). 
Table 2. Summary of Allegheny woodrat microsatellite polymorphism for populations and subpopulations sampled in West Virginia from 1999-2002. Variables are number of individuals captured $(\mathrm{N})$, expected and observed heterozygosity (He and Ho, respectively), and total number of alleles $(A)$ per locus. See Figure 2 for subpopulation abbreviations and distributions.

Table 3. Matrix of genetic variation among Allegheny woodrat subpopulations sampled from 2 study areas, 1999-2002 ( $\mathrm{F}_{\mathrm{st}}$ values are below the diagonal and $\mathrm{R}_{\mathrm{st}}$ are above the diagonal). All values are significantly different from zero after Bonferroni correction $(P<0.003)$. See Figure 3 for subpopulation abbreviations and distributions.

Table 4. Matrix of genetic variation $\left(\mathrm{F}_{\mathrm{st}}\right.$; below the diagonal) and gene flow estimates $\left(\mathrm{N}_{\mathrm{e}} \mathrm{m}\right.$; above the diagonal) for Allegheny woodrat subpopulations sampled from 2 study areas, 1999-2002. See Figure 3 for subpopulation abbreviations and distributions.

Table 5. Isolation by distance matrix of $\mathrm{F}_{\mathrm{st}} /\left(1-\mathrm{F}_{\mathrm{st}}\right)$ values (below the diagonal) and approximate spatial distances $(\mathrm{m})$ (above the diagonal) between subpopulations. See Figure 3 for subpopulation abbreviations and distributions.

Table 6. Isolation by distance matrix of $\mathrm{F}_{\mathrm{st}} /\left(1-\mathrm{F}_{\mathrm{st}}\right)$ values (below the diagonal) and approximate spatial distances $(\mathrm{m})$ (above the diagonal) between individual outcrops. Numbers in blue represent comparison among CR outcrops, green are among SH outcrops, and red are between CR and SH outcrops. See Figure 2 for outcrop distributions.75

Table 7. Results of maximum-likelihood assignment tests from six Allegheny woodrat subpopulations. Within each column, numbers in boxes represent the total number of correct assignments for that study area. The total number of classifications of sample size is represented by $n, \mathrm{CCOS}$ and $\mathrm{CCO}$ are the number of correct classifications observed at the subpopulations and study areas respectively, and \%CCOS and \%CCO are the percentages of correct classifications at each level. Area abbreviations and locations are shown in Figure 3 


\section{LIST OF FIGURES}

\section{CHAPTER 1.}

Figure 1. Study areas located in northcentral West Virginia sampled 1995-2003

\section{CHAPTER 2.}

Figure 1. Annual adult male (AM), adult female (AF), and juvenile (Juv) captures adjusted per 100 trap nights (CPUE) at Coopers Rock State Forest (a), West Virginia University Forest (b), and Snake Hill Wildlife Management Area (c) in West Virginia.

Figure 2. Annual adult male (AM), adult female (AF), and juvenile (Juv) captures between 1999 and 2003 adjusted per 100 trap nights (CPUE) at Coopers Rock State Forest (a) and Snake Hill Wildlife Management Area (b) in West Virginia.

Figure 3. Annual adult female to juvenile ratio between 1999 and 2003 adjusted per 100 trap nights (CPUE) at Coopers Rock State Forest (CR, $r=-0.41, P=0.49)$ and Snake Hill Wildlife Management Area (SH, $r=-0.77, P=0.22)$ in West Virginia.

Figure 4. Annual adult male (a), adult female (b), and juvenile (c) captures adjusted per 100 trap nights (CPUE) at Coopers Rock State Forest (CR), West Virginia University Forest (UF), and Snake Hill Wildlife Management Area (SH) in West Virginia compared with the previous fall's hard mast index.

Figure 5. Annual adult male (a), adult female (b), and juvenile (c) captures adjusted per 100 trap nights (CPUE) at Coopers Rock State Forest (CR), West Virginia University Forest (UF), and Snake Hill Wildlife Management Area (SH) in West Virginia compared with the current year's soft mast index.

Figure 6. Annual juvenile captures at all study sites in West Virginia adjusted per 100 trap nights (CPUE) and average winter temperature $\left({ }^{\circ} \mathrm{C}\right)$ for minimum winter temperature $(r=$ -0.85, $P=0.004)$, overall winter temperature $(r=0.76, P=0.02)$, and maximum winter temperature $(r=0.66, P=0.05)$. Values plotted are untransformed data.

Figure 7. Annual juvenile captures at all study sites in West Virginia adjusted per 100 trap nights (CPUE) and average spring snowfall $(\mathrm{cm})(r=-0.67, P=0.05)$. Values plotted are untransformed data.

Figure 8. Annual adult female captures at all study sites in West Virginia adjusted per 100 trap nights (CPUE) and average summer rainfall $(\mathrm{cm})(r=-0.75, P=0.02)$. Values plotted are untransformed data. 
Figure 9. Annual adult male captures at all study sites in West Virginia adjusted per 100 trap nights (CPUE) compared to minimum $(r=-0.80, P=0.01)$ and average $(r=-0.64, P=$ $0.06)$ summer temperature $\left({ }^{\circ} \mathrm{C}\right)$.

\section{CHAPTER 3.}

Figure 1. Study populations, Coopers Rock State Forest and Snake Hill Wildlife Management Area, and corresponding outcrops grouped into subpopulations based on neighbor-joining cluster analysis and geographic proximity of colonies (Castleberry et al. 2002).

Figure 2. Study populations, Coopers Rock State Forest and Snake Hill Wildlife Management Area, and individual outcrops sampled for genetic analysis (\#3 includes 2 outcrops because only one animal was captured at the smaller outcrop).

Figure 3. Study populations, Coopers Rock State Forest and Snake Hill Wildlife Management Area, and corresponding outcrops grouped into subpopulations based on linear topography of the outcrops and trapping records of recaptured individuals

Figure 4. Relationship between pairwise comparisons of genetic and spatial distance for six Allegheny woodrat subpopulations $(r=0.43 ; P=0.063)$.

Figure 5. Relationship between pairwise comparisons of genetic and spatial distance for nineteen Allegheny woodrat assemblages $(r=0.30 ; P=0.003)$.

Figure 6. Estimated distance from maternal woodrat $(\mathrm{m})$ to female and male offspring for individuals captured as juveniles and those recaptured as adults.

Figure 7. Estimated distance (m) between maternal woodrat and likelihood of maternal relatedness

Figure 8. Estimated distance from paternal woodrat $(\mathrm{m})$ to female and male offspring for individuals captured as juveniles and those recaptured as adults.

Figure 9. Estimated distance $(\mathrm{m})$ between paternal woodrat and likelihood of paternal relatedness 


\section{LIST OF APPENDICES}

Appendix A. List of common and scientific names for all species included in each mast

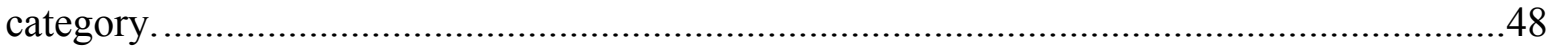

Appendix B. Allele frequencies listed by fragment length of nine microsatellite loci examined

in Allegheny woodrat populations breeding in northcentral West Virginia, 1999-2002 ......83 


\section{CHAPTER 1. INTRODUCTION AND LITERATURE REVIEW}

\section{INTRODUCTION AND OBJECTIVES}

Due to the behaviors and habitats of many wildlife populations that make research difficult, wildlife biologists are often compelled to make management decisions based on assumptions about the population in question. However, when a management action is based on misguided population parameters, there is the potential for detrimental effects on the species in question. When working with threatened or endangered species, smaller sample sizes and restrictive handling protocols further limit research sampling thereby heightening the potential for inaccurate results. With the constant advancement of scientific procedures, many management decisions can now be based on the combination of both field and laboratory techniques in efforts to more thoroughly understand wildlife populations that were previously misunderstood.

The Allegheny woodrat (Neotoma magister) is a rodent species that typically inhabits rocky outcrops throughout the Appalachian Mountains. In recent decades, the overall range has decreased significantly. The species is now considered endangered, threatened or a species of concern throughout the remainder of its range (Castleberry et al. 2001) and listed as lower risk and near threatened (LR/nt) by the International Union for Conservation of Nature and Natural Resources (Hafner 1996). Historically, research on the species has focused on taxonomic relations with the Eastern woodrat (Neotoma floridana). There have been some ecological studies suggesting possible causes for decline but a definitive reason has yet to be defined.

Because of the Allegheny woodrat's specificity to nest deep within rock crevices and caves, information regarding reproduction and other life history behaviors is questionable and the little that is known is based primarily on captive studies carried out by Poole in the 1940's. 
Reproductive success and potential recruitment are crucial factors to determining management options for conservation efforts.

Allegheny woodrat populations in the northcentral mountains of West Virginia are considered relatively stable. Over the past nine years, an intensive capture/recapture study has been carried out to create a clearer picture of the habits of this rodent species and the impact that anthropogenic disturbances have on the fate of the species. The overall goal of this effort was to develop long-term conservation strategies that will decrease the need for protection and management. The purpose of this research was to determine population structure, levels of gene flow, and relatedness among colonies within a specific study site to objectively define management units. Specific objectives were to:

1. determine population trends and correlations to environmental variables;

2. examine genetic structure and differentiation within and among subpopulations; and

3. determine potential parentage linkages and reproductive patterns.

\section{LITERATURE REVIEW}

Taxonomic Status

The Allegheny woodrat is a medium-sized rodent of the Sigmodontinae subfamily (Whitaker and Hamilton 1998). Historically, they have been known as the Appalachian woodrat (Baird 1857) or the Allegheny Cliff Rat (Stone 1893, Newcombe 1930). The first reference of this animal was in 1749 when Peter Kalm wrote about rats in high mountains among the stones and in subterraneous grottoes (Kalm 1771). Although it was assumed that he was referring to the black rat, they were also considered natives of North America (Pennant 1788). The next reference was in 1857 when Baird described what he called Neotoma magister based on skull 
fragments found in Pennsylvania caves (Baird 1857). However, the species was classified as extinct until 1893 when a living account was documented as Neotoma pennsylvanica, the Allegheny Cliff Rat (Stone 1893, Newcombe 1930). The relationship between these two species was questioned for some time due mainly to the paucity of specimens and the expansive range over which they were collected. In 1940, Poole (1940b) compared multiple specimens and determined that the range exceeded far beyond Pennsylvania and that the correct designation should in fact be $N$. magister.

Additional debate has occurred over the distinction between the Allegheny woodrat and the Eastern woodrat. Schwartz and Odum (1957) classified the latter as a subspecies of the Eastern woodrat because they believed the cranial and morphological differences used to previously distinguish the two species were merely a reflection of clinal variation in size. However, it was later discovered that skulls of Allegheny woodrats are distinctly different in that the anterior palatal spine is usually not bifurcated and a maxillovomerine notch is present (Hayes and Richmond 1993). In addition, analysis of mitochondrial restriction sites has indicated that $N$. magister is a separate lineage from $N$. floridana most likely due to the recent range expansion of a few individuals during the Pleistocene-Holocene transition (Hayes and Harrison 1992).

Historically, the Allegheny woodrat was found along the Appalachian Mountain system from southwestern New England to northern Alabama, and as far west as Indiana (Newcombe 1930, Poole 1940a). The southern distribution is apparently limited by the Tennessee River (Newcombe 1930, Whitaker and Hamilton 1998), which also is considered to distinguish the range of N. magister from N. floridana (Whitaker and Hamilton 1998). Although there is a possibility of hybridization in sympatric areas along the North Carolina and Tennessee border, there has been no evidence of hybridization between the two species (Birney 1973). Experiments 
with captive individuals attempting to force hybrid matings resulted in the Allegheny woodrat becoming aggressive and usually fatally attacking the Eastern woodrat (Birney 1973).

\section{Life History}

The Allegheny woodrat almost exclusively inhabits rock outcrops, cliffs, and talus slopes and caves in and around the hardwood forests of the central and southern Appalachians (Newcombe 1930, Poole 1940a). Adult male woodrats average approximately 350 to 450 grams (Hicks 1989) and range from 38 to $48 \mathrm{~cm}$ in length (Poole 1940a). Although similar in size to Norway and black rats, woodrats are distinguished by a bicolored, hairy tail and white underparts (Hicks 1989, Whitaker and Hamilton 1998). Furthermore, woodrats have longer vibrissae and a mid-ventral glandular area of exposed skin surrounded by discolored fur (Poole 1940a, Whitaker and Hamilton 1998). During the breeding season when animals are sexually active, this gland is more visible and odorous and potentially used to advertise whereabouts to the opposite sex (Poole 1940a). The breeding season is considered to run from early spring until mid-fall (Poole 1940a) with the majority of reproduction occurring in early spring and late summer (Mengak 2002). Juveniles have been observed as early as February and lactating females have been caught in October suggesting that reproduction may occur year round (Mengak 2002). Length of the reproductive season is thought to be dependent on mast crop and severity of winter (Whitaker and Hamilton 1998) as well as the risk of predation (Mengak 2002). Gestation is estimated from captive studies to be between 30 and 36 days (Poole 1936). Typical litter size from both field and captive studies is estimated between one to four pups with an average of two (Poole 1940a, Mengak 2002). As with many small mammal species, young are altricial at birth and maternally dependent (Poole 1936). 
Little is known about juvenile dispersal distances although it is assumed that like other mammalian species, males not only disperse more often but also greater distances than females (Greenwood 1980). Although males typically have larger home ranges, adult home ranges do not significantly differ between sexes and have been estimated at approximately 2 ha in intact forest (Castleberry et al. 2001). This estimate is larger than other Neotoma species possibly due to their specificity to rocky outcrops as these are not close to necessary food resources (Castleberry et al. 2001) Woodrats are generally considered herbivorous generalists (Newcombe 1930, Hicks 1989, Castleberry et al. 2002) although there are records of animals chewing on bones in captivity (Poole 1940a). Green vegetation, acorns and other hard mast, and fungi make up the majority of the woodrat diet throughout the year (Castleberry et al. 2002). Seasonal variations include soft mast and potentially arthropods during the spring and summer months when these items are most abundant (Poole 1940a, Castleberry et al. 2002). During the dormant season when such items are rare or unavailable, woodrats are known to cache food (Whitaker and Hamilton 1998, Castleberry et al. 2002).

It is possible that woodrats go undetected in areas where they occur due to their nocturnal behaviors and their specificity to remote, rocky areas not often traversed by humans (Whitaker and Hamilton 1998). Often their presence is indicated by their behaviors rather than by sight. They generally defecate on a common area, termed a latrine, that is a flat or slightly concave rock located outside the den (Poole 1940a). In addition, woodrats are often found near their food caches, which are termed middens that contain food and objects ranging from sticks and leaves to bones and feathers. Based upon their proximity to the nests, these piles are also presumed to aid in protecting the entrance to their den sites (Newcombe 1930, Whitaker and Hamilton 1998). 
Within the last few decades, the northern parts of the woodrat range have experienced steady declines in population sizes (Balcom and Yahner 1996). The Allegheny woodrat is now considered extirpated from Connecticut and New York and listed as threatened, rare, or a species of special concern throughout the remainder of its range which includes West Virginia, Virginia, Pennsylvania, Ohio, Indiana, Maryland, New Jersey, and North Carolina (Mengak 1996).

\section{Suspected Causes of Decline}

Although there are multiple theories of which factors contribute to the decline of the Allegheny woodrat, no specific threat is considered prominent. Because the northern populations have seemingly been most affected, one theory is simply that severe winters have altered the northern range forcing them to move south (Beans 1992). Another theory is that exposure to the ascarid roundworm (Baylisascaris procyonis) has impacted the population (LoGiudice 2003). The eggs of this parasite are found in raccoon (Procyon lotor) feces and infection occurs when woodrats consume seeds found in fecal matter, walk across contaminated sites, or carry intact feces back to their nests. Once infected, this disease is fatal to woodrats (Beans 1992, Balcom and Yahner 1996, Whitaker and Hamilton 1998). This threat seems to be more prevalent in the northern extent of the range (LoGiudice 2003). Previous studies throughout the Allegheny Mountains of West Virginia have found no evidence of B. procyonis infection in raccoons (Myers 1997, Owen et al. 2004).

Changes in forest composition may have a negative affect on woodrat populations. The defoliation of oaks due to infestation by the gypsy moth (Lymantria dispar) (Hall 1988) as well as the American chestnut (Castanea dentata) blight (Cryphonectria parasitica) are thought to reduce the availability of mast bearing trees and therefore decreased the food supply (Mengak 2002). Balcom and Yahner (1996) suggested that areas known to support woodrat populations in 
the past now have a greater percentage of coniferous forest cover including eastern hemlock (Tsuga canadensis) and white pine (Pinus strobes). This change in composition has decreased mast availability resulting in a reduction in optimal woodrat habitat. However, effects of clearcutting and diameter-limit harvests in West Virginia did not significantly impact woodrat home ranges and foraging distances when animals had access to intact forest (Castleberry et al. 2001). This impact is less severe when intact forest covers the outcrop and at least one adjacent side (Castleberry et al. 2001).

Balcom and Yahner (1996) also suggested that forest fragmentation has not altered woodrat abundance when compared to historical sites. However, the increase in agricultural and residential areas adjacent to the forest may have some effect on the population. Such areas are capable of supporting greater populations of great horned owls (Bubo virginianus), a potential woodrat predator (Whitaker and Hamilton 1998). These areas also experience greater raccoon populations, which in turn may increase the spread of the raccoon parasite (Balcom and Yahner 1996).

\section{Conservation Genetics}

Changes in the surrounding habitat isolate remaining woodrat populations, which can severely limit gene flow and lead to a reduction in genetic variability (Lande 1988). Adaptation to change is dependent on genetic diversity and consequently, a high level of genetic variability is considered a key factor when determining the health of a population (Slatkin 1987). Reduction of variability caused by fragmentation often impacts fitness traits and affects a species' longterm ability to respond to imminent and impending environmental changes (Slatkin 1987, Leberg 1990, van de Zande et al. 2000). 
The threat of isolating populations is even more significant when species occur naturally in metapopulations or discrete habitat patches, such as rocky outcrops. The inherent fragmentation that is already present and potentially limiting to both physical and genetic dispersal magnifies the effects of isolation within the surrounding area. As populations become smaller, they are more influenced by inbreeding, which reduces average individual fitness and genetic variability from random genetic drift (Lande 1988, Leberg 1990). Given the complexity

of influences such as dispersal and successful breeding, estimations of gene flow are difficult to assess (Slatkin 1987). However, for conservation strategies to be effective, managers must account for both demographic and genetic data at various scales. Conservation and management plans that are based on ambiguous genetic population structure may accelerate declines and potentially lead to local extinction events. It is important for managers to understand and preserve genetic variation for its short-term influence on population viability, as well as to maintain a population's evolutionary flexibility (Leberg 1990).

\section{STUDY AREA}

This study was conducted on Coopers Rock State Forest (CR) and Snake Hill Wildlife Management Area (SH), located in Monongalia and Preston Counties, West Virginia (Fig. 1). CR is located approximately $20 \mathrm{~km}$ east of Morgantown, West Virginia and $13 \mathrm{~km}$ west of Bruceton Mills, West Virginia and encompasses over 5300 ha. Access is gained primarily from Interstate 68 (I-68), which runs in an east-west direction and bisects the forest into a northern and southern section. The northern portion of CR, called the West Virginia University Research Forest (UF), is leased by West Virginia University (WVU) and used as an experimental forest managed for outdoor laboratories and research by the West Virginia University Division of Forestry. Due to differences in trapping efforts and to the presence of I-68, UF was treated as a 
separate study area and analyzed separately from CR but will be described under CR. Trapping occurred throughout all three study areas but was concentrated in the southern portion of CR which is primarily used for public recreation and scenic viewing of the gorge formed by the Cheat River. The river forms the forest's southern border and flows in a northwesterly direction, forming a $400 \mathrm{~m}$ deep gorge. $\mathrm{SH}$ is located directly across the river almost $5 \mathrm{~km}$ north of Dellslow, West Virginia along county Routes 75 and 75/2 and covers approximately 800 ha.

CR originally was used by the iron ore industry, which peaked between 1798 and 1848 . The last furnace closed in 1868 at which time the land went through various owners who used the area primarily for harvest of American chestnut, white oak (Quercus alba) and Northern red oak (Q. rubra). SH had similar forest disturbances caused by timbering operations and fire. Prior to the influence of the timber industry, the forests were mainly oaks and chestnut at higher elevations, with Eastern hemlock, American beech (Fagus grandifolia), black walnut (Juglans nigra), and associated species typically found at lower elevations. Harvest of CR continued until 1936 when the West Virginia Conservation Commission purchased the majority of the forest. SH is presently owned and managed by the West Virginia Division of Natural Resources (WVDNR). However, the WVDNR does not own the timber rights so future timbering of the area is expected. Both forests have seen periodic management harvests in the past but the primary use of the land is public recreation (Andrew Dick, pers. comm.)

All three study areas are part of the Chestnut/Laurel Ridges of the western edge of the Appalachian Mountains. The Pennsylvania Game Commission (1996) has defined woodrat colonies existing within this region as part of the Chestnut/Laurel Ridge metapopulation. Elevations range from $257 \mathrm{~m}$ to $796 \mathrm{~m}$ at CR and $214 \mathrm{~m}$ to $661 \mathrm{~m}$ at SH (USGS National Elevation Dataset). Erosion has been primarily due to streams as opposed to igneous or glacial 
activity. The Chestnut Ridge anticline contains surface rocks that are sedimentary and exposed rock layers that are predominately sandstones, shales and limestones. In addition to exposed outcroppings, all sites have abundant large sandstone boulders and pilings of talus, which have been determined to be critical habitat for woodrats (Myers 1997, Chamblin et al. 2004).

Soils found throughout the southeast end of Monongalia County are mainly Buchanan and Ernest very stony soils (Soil Conservation Service 1982). Dekalb Complex is the most common soil type although Ernest, Gilpin, Tilsit, Udorthents, and Upshur-Belmont are also found throughout the county. The most common soil type within the Preston County line of CR is Delkalb Complex accounting for approximately $70 \%$ of the area (Soil Conservation Service 1954). The remaining area within Preston County is made up of the Ernest Complex and Gilpin. All types found throughout both counties are fairly well suited for wildlife that requires hardwood and herbaceous plants.

All three study areas are within the mixed mesophytic region of the Appalachian mountain region characterized by Braun (1950). Over $50 \%$ of the area studied is dominated by oak-hickory communities (Eyre 1980, USGS GAP Analysis Program 2002), which are common along dry southern slopes and ridges (Braun 1950). Typical of the mixed mesophytic forest, species such as yellow-poplar (Liriodendron tulipifera), yellow birch (Betula alleghaniensis), red maple (Acer rubrum), and black cherry (Prunus serotina) are also commonly found (Braun 1950). The remaining area is distinguished as mixed mesophytic hardwoods (20\%), mountain hardwoods ( $2 \%$ to $9 \%)$, hardwood/conifers ( $3 \%$ to $12 \%)$ and cove hardwoods ( $2 \%$ to $4 \%$ ) (USGS GAP Analysis Program 2002). 


\section{STUDY ORGANIZATION}

The research findings presented are organized into 2 chapters. In chapter 2, I present trapping data from the last nine years for different groups of captures at all three study areas. I also examine possible explanations for the current status of the woodrat population by looking at environmental variables. Chapter 3 examines genetic variation and differentiation at $\mathrm{CR}$ and $\mathrm{SH}$ at various spatial scales based on data collected since 1999. Parentage was also determined for juvenile captures.

\section{LITERATURE CITED}

Baird, S. F. 1857. Mammals of North America, p. 498 (in account of Neotoma ocidentalis).

Balcom, B. J., and R. H. Yahner. 1996. Microhabitat and landscape characteristics associated with the threatened Allegheny woodrat. Conservation Biology 10:515-525.

Beans, B. E. 1992. Without a trace: the puzzling demise of the Allegheny woodrat. Audubon 92:32-34.

Birney, E. C. 1973. Systematics of three subspecies of woodrat (genus Neotoma) in central North America. Miscellaneous Publications, Museum of Natural History, University of Kansas, $58: 1-173$.

Braun, E. L. 1950. Deciduous forests of eastern North America. Hafner Press. New York, NY.

Castleberry, N. L., S. B. Castleberry, W. M. Ford, P. B. Wood, and M. T. Mengak. 2002. Allegheny woodrat (Neotoma magister) food habits in the Central Appalachians. The American Midland Naturalist 147:80-92.

Castleberry, S. B., W. M. Ford, P. B. Wood, N. L. Castleberry, and M. T. Mengak. 2001. Movements of Allegheny woodrats in relation to timber harvesting. Journal of Wildlife Management 65:148-156. 
Chamblin, H. D., P. B. Wood, and J. W. Edwards. 2004. Allegheny woodrat (Neotoma magister) use of rock drainage channels on reclaimed mines in southern West Virginia. American Midland Naturalist 151:346-354.

Deston-Fearing Corporation. 1994. Mini portable reader MPR user manual. South St. Paul, Minnesota.

Eyre, F. H. ed. 1980. Forest cover type of United States and Canada. Library of Congress, Washington, D. C.

Greenwood, P. J. 1980. Mating systems, philopatry and dispersal in birds and mammals. Animal Behavior 28:1140-1162.

Hafner, D. J. 1996. Neotoma magister. In: IUCN 2003. 2003 IUNC Red List of Threatened Species. www.redlist.org.

Hall, J. S. 1988. Survey of the woodrat in Pennsylvania. Final report. Pennsylvania Game Commission.

Hayes, J. P., and R. G. Harrison. 1992. Variation in mitochondrial DNA and the biogeographic history of woodrats (Neotoma) of the eastern United States. Systematic Biology 41:331344.

Hayes, J. P., and M. E. Richmond. 1993. Clinal variation and morphology of woodrats (Neotoma) of the eastern United States. Journal of Mammalogy 74:204-216.

Hicks, A. 1989. Whatever happened to the Allegheny woodrat? Pages 34-38 in The Conservationist (March-April). New York State Dept. Environmental Conservation, Albany, New York.

James, F. C., and H. H. Shugart. 1970. A quantitative method of habitat description. Audubon Field Notes 24:727-736. 
Kalm, P. Travels into North America ( $2^{\text {nd }}$ ed.). London. Printed for T. Lowndes, No 77, in Fleetstreet. 1772.

Lande, R. 1988. Genetics and demography in biological conservation. Science. 241:1455-1460.

Leberg, P. L. 1990. Influence of genetic variability on population growth: implications for conservation. Journal of Fish Biology. 37:193-195.

LoGiudice, K. 2003. Tropically transmitted parasites and the conservation of small populations: raccoon roundworm and the imperiled Allegheny woodrat. Conservation Biology 17:258266.

Mengak, M. T. 1996. Status and distribution of woodrat populations in Virginia. Pages 2-3 in Abstracts of the 1996 Allegheny Woodrat Recovery Group Meeting, Ferrum College, Ferrum, Virginia. . 2002. Reproduction, juvenile growth and recapture rates of Allegheny woodrats (Neotoma magister) in Virginia. American Midland Naturalist 148:155-162.

Myers, R. T. 1997. Microhabitat and ecology of the Allegheny woodrat in northcentral West Virginia. M. S. Thesis, West Virginia University, Morgantown, West Virginia, 84 pp.

Newcombe, C. L. 1930. An ecological study of the Allegheny cliff rat (Neotoma pennsylvanica stone). Journal of Mammalogy 11:204-211.

Owen, S. F., J. W. Edwards, W. M. Ford, J. M. Crum, and P. B. Wood. 2004. Raccoon roundworm in raccoons in Central West Virginia. Northeastern Naturalist 11:137-142.

Pennant, T. 1788. Arctic Zoology, pp. 150-151.

Pennsylvania Game Commission. 1996. Allegheny Woodrat Site Survey Code Manual. Bureau of Wildlife Management, Harrisburg, Pennsylvania. 11pp. 
Poole, E. L. 1940a. A life history sketch of the Allegheny woodrat. Journal of Mammalogy 21:249-270. . 1940b. The technical name of the Allegheny woodrat. Journal of Mammalogy 21:316318. . 1936. Notes on the young of the Allegheny woodrat. Journal of Mammalogy 17:22-26.

SAS Institute. 2001. SAS Institute, Cary, North Carolina.

Schwartz, A., and E. P. Odum. 1957. The woodrats of the eastern United States. Journal of Mammalogy 38:197-206.

Slatkin, M. 1987. Gene flow and the geographic structure of natural populations. Science. 236:787-7992.

Soil Conservation Service. 1954. Soil survey, Preston County, West Virginia. . 1982. Soil survey of Marion and Monongalia Counties, West Virginia.

Stone, W. 1893. Description of the new species of Neotoma from Pennsylvania. Proceedings Academy of Natural Sciences of Philadelphia, p. 16.

USGS GAP Analysis Program 2002, http://www.gap.uidaho.edu.

USGS National Elevation Dataset, http://edc.usgs.gov/geodata.

Whitaker, J. O., Jr., and W. J. Hamilton, Jr. 1998. Mammals of the Eastern United States. Cornell University Press. Ithaca, NY. 


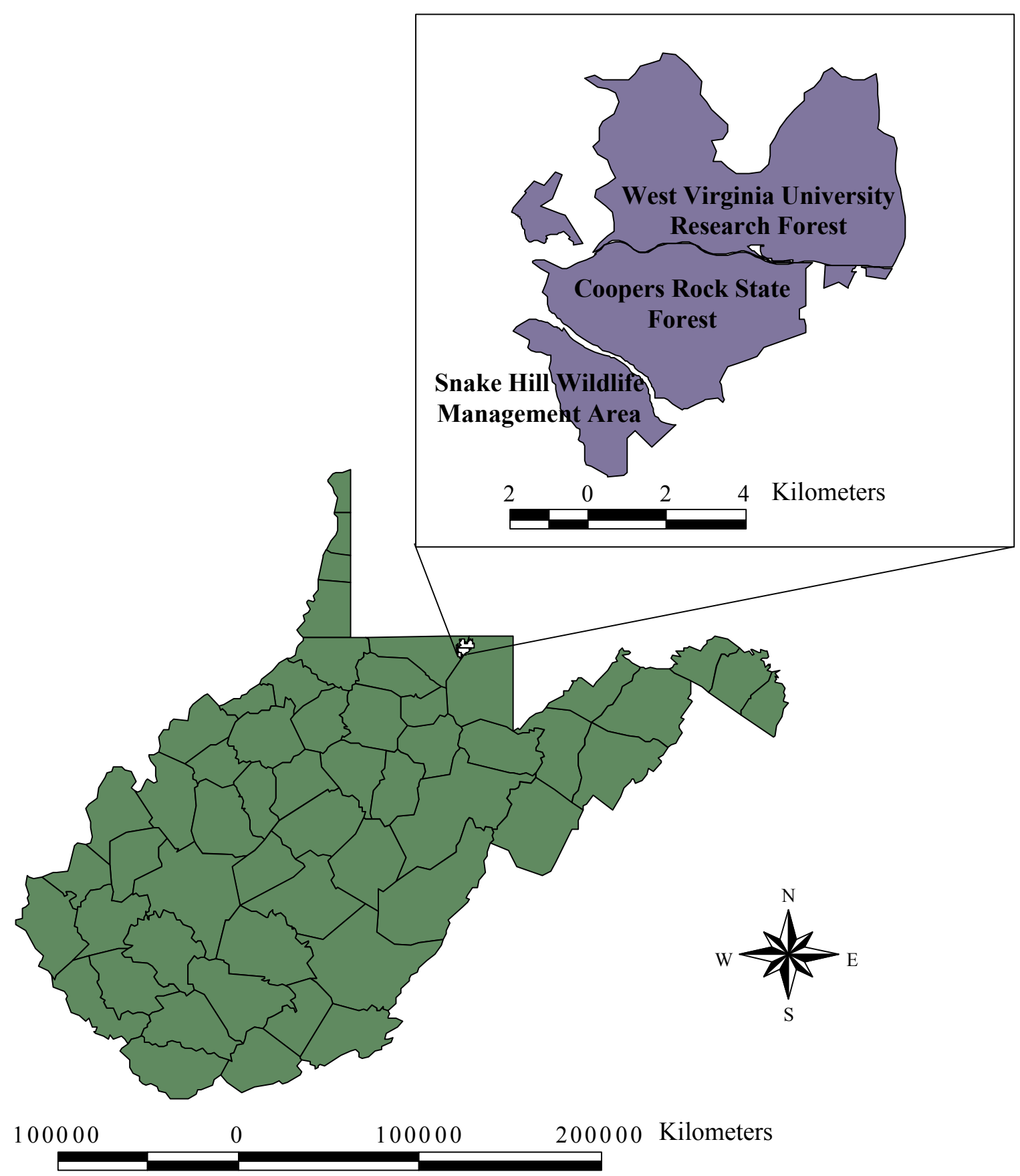

Figure 1. Study areas located in northcentral West Virginia sampled 1995-2003. 


\title{
CHAPTER 2. ALLEGHENY WOODRAT POPULATION TRENDS IN NORTHCENTRAL WEST VIRGINIA
}

\begin{abstract}
Allegheny woodrat populations have been declining in recent decades over the entirety of their range. Over the past nine years, an ongoing mark/recapture survey has been carried out on a woodrat population in northcentral West Virginia to gain a better understanding of the population's status. Overall captures were not significantly different among 3 study areas but yearly variations were observed $(P=0.10)$. Declines occurred in adult females overall but most significantly at CR $(r=-0.75, P=0.02)$ and SH $(r=-0.85, P=0.07)$. Variability in hard and soft mast production was not significantly related to woodrat captures. Lower winter temperatures $(r$ $=0.76, P=0.02)$ and higher spring snowfall $(r=-0.67, P=0.05)$ negatively affected juvenile captures. Adult female captures were negatively correlated to summer rainfall $(r=-0.75, P=$ $0.02)$ and adult male captures were negatively related to summer temperatures $(r=-0.64, P=$ 0.06). Results support the suggestion that woodrats in northern states are negatively impacted by the severity of winter. Given the negative yearly trend and the significant decline in adult females, the population must be further monitored to understand the future of these rodents.
\end{abstract}

\section{INTRODUCTION}

The Allegheny woodrat (Neotoma magister) typically inhabits rocky outcrops throughout the Appalachian mountains. In recent decades, this rodent species has become a focus of research due to unexplained population declines throughout the entirety of its range. Many theories have been suggested for this reduction in population including the impact of the ascarid roundworm (LoGiudice 2003), reduction in mast producing species (Mengak 2002), and/or severity of winters (Beans 1992). Because different parts of the range have experienced different influences, the most likely scenario is that combinations of factors negatively affect woodrat populations and

This chapter written in the style of the Journal of Wildlife Management. 
that the impacts are highly dependent on the area being examined.

The current population of interest has been intensively trapped for the last nine years as part of an ongoing mark/recapture study. Given the long-term nature of this data set, the main objectives of the current research were to examine population status and to determine if any environmental variables including mast, temperature, and precipitation are influencing the woodrat population.

\section{STUDY AREA}

This study was conducted on Cooper's Rock State Forest (CR), West Virginia University Research Forest (UF), and Snake Hill Wildlife Management Area (SH), all located in northcentral West Virginia (Refer to Ch.1, Fig. 1). UF is approximately 3200 ha and lies to the north of CR. SH lies to the west of CR and is the smallest area (800 ha). CR is where the majority of the trapping occurred and encompasses about 2100 ha. All three areas are used for public recreation but UF also is used as a research forest for West Virginia University. The areas are bordered by Interstate 68, running east-west and separating CR and UF, and the Cheat River, which flows north-west and separates $\mathrm{CR}$ and SH. All are part of the mixed mesophytic region of the Appalachian Mountains with predominately oak-hickory species but supporting a variety of hardwood species (Braun 1950).

\section{METHODS}

Field

Trapping began at CR and UF in 1995 and at SH in 1999 with effort varying among years. From September 1995-May 1997, 72 rock outcrops were trapped at least once (Myers 1997). In 1998, a small number of select outcrops were trapped to determine presence/absence. 
Between May 1999 and October 2000, Zuck (unpub. data) trapped specific outcrops on CR that were known to have woodrat populations from earlier trapping efforts and on $\mathrm{SH}$ to determine if woodrats were present. Each site was trapped at least once in 1999 and twice in 2000. From September 2001-October 2003, I trapped outcrops from the 1999-2000 trapping that had the highest history of woodrat captures once during the fall of 2001, three times between May and October 2002, and twice from May to October 2003.

Tomahawk live traps $(13 \mathrm{~cm} \times 13 \mathrm{~cm} \times 40 \mathrm{~cm} ; 15 \mathrm{~cm} \times 15 \mathrm{~cm} \times 48 \mathrm{~cm}$; Tomahawk Live Trap Co., Tomahawk, Wisconsin) were baited with apples and set in level areas under exposed rock ledges and within rock crevices such that exposure to the elements was reduced. The number of traps placed along each outcrop varied with outcrop length and traps were placed near latrines, middens and potential nest sites. Traps were set during the afternoon and checked the following morning for a consecutive 2-night sampling period consistent with most state woodrat trapping surveys. To avoid potential hypothermia of captured animals, traps were packed with polyfil when temperatures were below $10^{\circ} \mathrm{C}$ and were not set if temperatures dropped below $4^{\circ}$ C.

Once an animal was captured, the sex and reproductive status was recorded if possible while the animal was still in the trap to minimize stress. Reproductive status for males was either scrotal (S) or nonscrotal (NS) and for females was pregnant (P), lactating (L), post-reproductive (PR), or not yet mature (N/A). Condition of the mid ventral gland was recorded for the 19972003 captures. The mid-ventral gland was recorded as 0 if not visible, 1 if narrow and surrounded by fur and 2 if the area was wide, bare skin and oily. If the animal was a recapture from the previous day, the identification was verified and the animal was released. If a new animal was captured, or an animal was recaptured from a previous trapping event, the animal 
was weighed and assigned an age class based on mass and pelage coloration similar to previous studies (Castleberry et al. 2001, Castleberry et al. 2002, Mengak 2002, Chamblin et al. 2004). Juveniles weighed less than $200 \mathrm{~g}$ with gray dorsal pelage and adults weighed more than $200 \mathrm{~g}$ with brown dorsal pelage. Animals that escaped before identification or whose capture status were questionable due to a lost ear tag were removed from statistical analyses to avoid counting the same animal twice.

All individuals were tagged with a single \#1005-1 monel numbered aluminum ear tag (National Band and Tag Co., Newport, Kentucky) and/or a unique passive integrated transponder (PIT) tag (Electronic ID, Inc. Cleburne, Texas; Deston-Fearing Corp., South St. Paul, Minnesota) inserted in the subcutaneous fascia between the scapulae. This work was completed under West Virginia University Animal Care and Use Committee permit \# 01-0302.

Vegetation was sampled within CR and SH during August 2002 using a 0.04 ha plot evenly quartered using $11.2 \mathrm{~m}$ transects in the four cardinal directions (James and Shugart 1970). Characteristics that are known to be of importance to woodrats due to diet and cover requirements were measured (Table 1). Ground cover variables and overstory were measured on five points along each transect and calculated as a percent of each plot. All shrubs, saplings and poles that fell within one meter of the four transects were recorded to species. Shrubs were measured as any plant $<3 \mathrm{~cm}$ diameter breast height $(\mathrm{DBH})$ and $<2 \mathrm{~m}$ high. Saplings were labeled as any plant $<3 \mathrm{~cm} \mathrm{DBH}$ that was $>2 \mathrm{~m}$ high. Poles were classified by anything 3 to 8 cm DBH. All trees $>8 \mathrm{~cm}$ DBH were identified to species and stem densities were counted within the entire 0.04 ha plot. The number of plots within an outcrop varied with rock outcrop length; the first plot was placed at $50 \mathrm{~m}$ and subsequent plots were at $100 \mathrm{~m}$ intervals. Given the rugged topography of the rock sites and the extreme slopes, plots were not always on a level 
plane and some plots included vegetation along the outcrop as well as above and/or below. Plots that fell within two parallel outcrops were taken at the midpoint of the two. Slope and aspect also were recorded at the center of each vegetation plot.

Because mast producing species are prevalent in mixed mesophytic forests (Braun 1950) and important to woodrats (Castleberry et al. 2002), tree and shrub species were given a mast code (Appendix A) based on type of mast produced [hard mast (HM), soft mast (SM), other (O)]. Seed producing species such as Eastern hemlock and maple are important components of woodrat diets and also were categorized as hard mast (Castleberry et al. 2002, Chamblin et al. 2002). Regional mast production data were available from yearly surveys conducted by the West Virginia Division of Natural Resources (WVDNR). Monongalia and Preston counties are part of WVDNR region 4, which also includes Taylor, Marion, Harrison, Lewis, Barbour, Upshur, and Braxton Counties.

Climatic data was collected annually at the Coopers Rock Weather Station, located in the UF study area. Based on records for the last 10 years, the area experienced average annual rainfall of $73.3 \mathrm{~cm}$ and average snowfall of $109.3 \mathrm{~cm}$. Average winter (November through March) precipitation and snowfall were $28.9 \mathrm{~cm}$ and $102.6 \mathrm{~cm}$, respectively. Spring (April and May) precipitation and snowfall were $15.7 \mathrm{~cm}$ and $6.7 \mathrm{~cm}$ while summer (June through October) averaged $28.7 \mathrm{~cm}$ rainfall and no snow. Seasonal temperatures averaged $-0.8^{\circ} \mathrm{C}$ in the winter, $8.7^{\circ} \mathrm{C}$ during the spring and $14.1^{\circ} \mathrm{C}$ in the summer with an annual average low and high of $4.2^{\circ} \mathrm{C}$ and $13.6^{\circ} \mathrm{C}$, respectively. Precipitation variables considered are average rainfall, including melted snow, and average snowfall including both ice pellets and hail. 
Statistical Analyses

Statistical analyses were completed using the Statistical Analysis System (SAS Version 8, SAS Institute, Inc. 2001). Variables not fitting the assumptions of normality were log transformed prior to statistical analyses. All results were considered significant at $P<0.05$. Habitat variables were averaged across study areas and compared for differences among areas using an equality of variance of $P=0.01$ and the Student $t$-Test (PROC TTEST).

Capture statistics initially were analyzed using data collected over all nine years. Captures were summarized as total individuals, adult males, adult females, juvenile males and juvenile females at each study area and rock outcrop. For animals captured multiple times per year, only the first capture was included per year. Due to yearly differences in trapping efforts, relative abundance was standardized as a catch per unit effort (CPUE) calculated as the number of individuals per 100 trap nights. Trap nights were adjusted by subtracting one-half trap night for each sprung trap including those missing bait, flipped over, or with incidental captures (Nelson and Clark 1972, Beauvais and Buskirk 1999). Because differences in the number of outcrops trapped throughout the years may have affected the numbers of individuals captured, a subset of outcrops at $\mathrm{CR}(n=10)$ and $\mathrm{SH}(n=3)$, that were trapped for at least four of the last five years, was created. Yearly trends for both the nine-year dataset and the five-year subset were examined using a mixed model ANOVA with captures as the dependent variable and study area as the class variable. The data subset was also used to determine capture differences among outcrops. Years were treated as a continuous variable (PROC GLM). Captures were tested for significant trends over time at each study area and outcrop using Pearson product-moment correlation (PROC CORR). 
Mast production was correlated with woodrat abundance at each study area using Pearson product-moment correlation. Because hard mast from preceding years is known to have a positive and significant relation to densities of rodents in subsequent years (Wolff 1996), mast from the previous year was compared to the following year captures. However, soft mast is most abundant during the spring and summer months (Castleberry et al. 2002) and was compared with captures from the current year. Study areas initially were analyzed separately to determine if there was a study area effect. However, mast indexes were calculated at a regional level. To determine possible effects of mast on capture success at a regional level, annual captures were averaged across all three study areas and adjusted for trap nights.

Regional CPUE also was used to examine relations to temperature and precipitation. These variables were examined for all groups using Pearson product-moment correlation. Precipitation was separated into snowfall and rainfall and summed for each month and corresponding season for each trapping year. Temperature variables were averaged for each month and corresponding season. Because the majority of trapping occurred between June and October of each year, this was considered the summer season. Winter included November and December of the previous year plus January through March of the current year. Spring was considered April and May. I examined correlations of summer captures to summer weather variables and to the previous winter and spring weather variables.

Mast production also was tested with temperature and precipitation variables to determine if mast abundance was related to weather. Hard mast was analyzed with the subsequent winter and the preceding spring and summer weather data while soft mast was compared with the previous winter and the current spring and summer. 


\section{RESULTS}

Trapping Success

During 1995-2003, 442 individual woodrats [146 adult males (AM), 170 adult females (AF), 59 juvenile males (JM), 67 juvenile females (JF)] were identified at CR (Table 2). Annual CPUE averaged 7.0 and varied from 4.7 to 10.6 (Table 2). An average of $26.1 \%$ of total captures were animals captured from previous years with females recaptured most frequently $(38.8 \%)$ (Table 3).

Trapping occurred extensively at UF from 1995 to 1997 with sporadic efforts in subsequent years. A total of 92 individual woodrats (26 AM, 41 AF, 9 JM, 16 JF) were identified with an annual average CPUE of 3.1 varying among years from 1.5 to 6.3 (Table 2). An average of $19.7 \%$ of total captures were animals captured from previous years with females recaptured almost twice as often as males (28.3\% vs. $14.3 \%)$ (Table 3$)$.

SH was trapped over five years with 83 individual woodrats (33 AM, 34 AF, 9 JM, 7 JF) captured (Table 2). Average CPUE was 4.4 and ranged between 1.0 and 7.2 (Table 2). Although captures of adult males and females were similar, adult females were recaptured more often (27.1\% vs. $23.5 \%)$ (Table 3$)$.

Total captures were similar among study areas but differed among years for adult females (Table 4). When separated by study area over the nine years, adult females demonstrated a significant negative trend at CR (Fig. 1a). Although no other significant trends occurred at $\alpha=$ 0.05, total captures at CR (Fig. 1a) and female captures at SH (Fig. 1c) approached significance. The subset of outcrop specific captures from 1999-2003 showed similar results. Captures differed among years for adult females (Table 5) and when separated by study area, CR showed a negative trend in AF captures over time (Fig. 2a). Total captures at CR (Fig. 2a) and AF 
captures at SH (Fig. 2b) approached significance. The ratio of adult females to juvenile captures was not significant among years but varied at CR from 0.81 to 2.17 and at $\mathrm{SH}$ from 4.33 to 0.67 (Fig. 3).

Adjusted captures were evaluated at the level of the specific rock outcrop. Differences were detected among years and outcrops in overall captures, adult female captures, and juvenile captures (Table 6). Adult female captures significantly decreased at three of twelve outcrops; juvenile captures increased at two outcrops.

Habitat

Habitat variables that were significantly greater at $\mathrm{SH}$ were slope, percent canopy cover, and percent green ground cover (Table 7). Ground cover percentages were higher at CR for woody debris and non-cover variables. Stem densities of soft mast species were significantly higher at CR but overall stem densities were higher at SH for shrubs, saplings, poles and immature species.

Analysis of woodrat captures and hard mast of the previous year resulted in no significant correlations for all study areas and all three groups of woodrats (Fig. 4). There also were no significant correlations between capture success and soft mast production of the same year (Fig. 5). Combining all captures did not show any significant correlation although overall captures compared to soft mast indexes did approach significance $(r=0.59 ; P=0.09)$. Soft and hard mast production were not significantly related to average temperature or total precipitation in any season. 
Weather

Temperature and precipitation were significantly related to juvenile captures (Table 8). Overall juvenile captures increased as minimum, maximum and average winter temperature increased (Fig. 6). Juvenile captures significantly increased as spring snowfall decreased (Fig. 7). Captures of adult females decreased when summer rainfall increased (Fig. 8). Adult male captures decreased as summer minimum and average temperatures increased (Fig. 9).

\section{DISCUSSION}

The overall number of woodrats captured varied annually between 1995 and 2003 but not significantly and was not different among the three study areas. Because there was a difference in number of outcrops trapped each year and trapping intensity between study areas, I examined a subset of the data to reduce bias from inconsistent trapping efforts. Specific outcrops that were trapped consistently over the last five years at CR and SH were analyzed to determine if differences in trapping efforts affected the outcome between study areas. The overall CPUE was not significantly different between the study areas suggesting that both areas are equally capable of supporting woodrat populations. Yearly variation did approach significance $(P=0.07)$ indicating that there has been some decrease in the population over time.

The yearly variation in overall captures was due primarily to decreased captures of adult females, in both datasets tested. Differences in adult female captures between study areas from the last five years approached significance $(P=0.09)$. It is possible that there are differences between study areas affecting specific group dynamics. When the study areas were analyzed by year, both areas showed a negative trend in adult female captures. This unfavorable trend in woodrat population was observed at the level of the overall study area as well as when individual outcrops were analyzed. Each outcrop was trapped multiple times per year in an effort to catch 
all animals. The fact that individual adult females most frequently were captured and recaptured at the same outcrop suggests females are more philopatric. The lower overall recapture rate of males and the higher recapture rate at other outcrops suggests that males are more actively dispersing, a common behavior among mammals (Greenwood 1980). Therefore, the negative trend in adult female captures may be indicative of the entire population but immigration and emigration between outcrops that were not sampled masked that decline in male and juvenile captures. Juvenile captures were not significantly declining over years at the study area level. The ratio between adult female captures and juvenile captures did vary between years but this variation was not significant and may be a result of sampling differences. When individual outcrops were analyzed, juveniles did increase throughout the years at specific outcrops. Therefore, it does not seem that fecundity is being negatively affected throughout this population.

Rodent fecundity is often directly related to food availability because years of abundant mast production have been shown in some species to extend the breeding season and increase populations in subsequent years (Smyth 1966, Gashwiler 1979, Wolff 1996). Because mast is a significant component in woodrat diets, the reduction of mast often has been suggested as a potential threat to the Allegheny woodrat (Balcom and Yahner 1996). No significant correlations were detected between yearly CPUE of all groups with the previous year's hard mast and the current year's soft mast indices. It is possible that their generalist diet and food caching behaviors are suitable for survival throughout winter months and years of lower mast production (Castleberry et al. 2002). Other woodrat species have been shown to demonstrate opportunistic foraging behavior in which diet selection shifts in response to food availability (McMurry et al. 1993). Balcom and Yahner (1996) studied woodrat populations in Pennsylvania and found that 
sites historically occupied by woodrats had a significantly greater percentage of coniferous and mixed forest cover when compared to presently occupied sites. Although they attributed the absence of woodrats at historical sites to changes in forest composition (particularly food availability), it is possible that woodrat extirpation from these sites was related to another factor given the ability of woodrats to shift diet selection in response to habitat change (McMurry et al. 1993).

Although no significant correlations were observed with capture success, the mast index tested was a regional percentage and not specific to the study areas (Fig. 10). Therefore, the comparison does not indicate whether mast abundance within study areas is a factor relating to capture success. Habitat variables at $\mathrm{CR}$ and $\mathrm{SH}$ were compared for differences in stem densities of mast producing species. CR did have significantly higher abundance of soft mast species. Although mature hard mast species were similar between the areas, captures generally did not differ among study areas, indicating mast differences are probably not related to the capture success of woodrats. Individual outcrops did show significant differences, which may be due to differences in the habitat at each outcrop. However, sample sizes were not large enough to test this hypothesis.

Temperature and precipitation appeared to play a role in woodrat captures. Juvenile captures in summer increased when winter temperatures increased. Juvenile captures also were greater at higher average and minimum spring temperatures $(P=0.10)$. Offspring are typically born in spring but field observations have reported sightings of juveniles as early as February (Mengak 2002). Young born during late winter and early spring may experience a greater threat to their survival in years with lower temperatures (Fig. 11). Directly related to temperature was the fact that juvenile captures were negatively related to spring snowfall although the excessive 
level of spring snowfall in 2001 (Fig. 12) may have strongly influenced this result. These results support the hypothesis that severity of northern winters has impacted the northern ranges of woodrat populations (Beans 1992). However, within the CR and SH populations, overall juvenile captures did not decrease throughout years. Therefore, winter temperatures may be affecting juvenile survivorship or the impacts on juveniles may be a result of winter weather affecting adult reproduction. Given field observations and reproductive patterns of other rodent species, woodrats most likely are reproductive 'opportunists', breeding continuously when conditions allow. The increase in energetic demands brought on by a severe winter may limit or inhibit reproduction and result in a reduction of juveniles (Bronson 1989).

Summer weather variables affected both adult male and female captures but there does not seem to be definitive reasons as to why these demographics are more affected than others. Males were captured less frequently with increasing summer temperatures, which may be due to a reduction in movement during periods of higher temperatures. Adult female captures were negatively correlated to summer rainfall. It is possible that females simply went undetected or were moving less during summers with greater rainfall. Although there were no significant correlations between weather and mast indexes, it does appear that years of heavy rainfall may reduce mast production. In recent years, there has been a significant increase in rainfall that could affect food resources. Females may be more affected because they typically have smaller home ranges and consequently less food resources available.

\section{CONCLUSION}

Given the overall success of trapping efforts within the Chestnut/Laurel Ridge population, it is considered relatively healthy compared to other states throughout the woodrat's range. However, the results of this long-term study suggest that the negative trend in adult 
female captures may be an indication that, like other areas throughout the range, the population is declining. This suggestion is not supported by the fact that juvenile and male captures were not declining overall. It may be possible that this is a result of immigration from additional outcrops that were not sampled. If areas that were not sampled are stable and dispersal is not impeded or limited, then it seems probable that this population will continue to exist. However, if the decline of adult females is population wide, then the future of this population is questionable. The cause of the trends seen is unknown but the most significant influence seems to be weather. Juvenile captures were highly dependent on winter temperatures suggesting that colder winters negatively affect juvenile survivorship or limit the breeding season. Although weather patterns are highly variable and cyclic, the study population has evolved and existed for centuries under such conditions. Therefore, the correlation between captures and weather may be a result of other factors that impact body reserves and make winter survival more difficult such as the reduction of mast or disease. Although mast does not seem to be a limiting factor, future timbering of the forests should leave adequate mast producing species especially if this is critical factor for winter survival. It is also possible that, like other rodent species, the population is cyclic and will begin to increase. Continuous monitoring is necessary for a better indication of the local population's status and health.

\section{LITERATURE CITED}

Balcom, B. J., and R. H. Yahner. 1996. Microhabitat and landscape characteristics associated with the threatened Allegheny woodrat. Conservation Biology 10:515-525.

Beans, B. E. 1992. Without a trace: the puzzling demise of the Allegheny woodrat. Audubon 92:32-34. 
Beauvais, G. P. and S. W. Buskirk. 1999. Modifying estimates of sampling effort to account for sprung traps. Wildlife Society Bulletin 27:39-43.

Beers, T. W., P. E. Dress, and L. C. Wensel. 1966. Aspect transformation in site productivity research. Journal of Forestry 64:691-692.

Braun, E. L. 1950. Deciduous forests of eastern North America. Hafner Press. New York, NY.

Bronson, F. H. 1989. Mammalian reproductive biology. The University of Chicago Press, Chicago, Illinois.

Castleberry, N. L., S. B. Castleberry, W. M. Ford, P. B. Wood, and M. T. Mengak. 2002. Allegheny woodrat (Neotoma magister) food habits in the Central Appalachians. The American Midland Naturalist 147:80-92.

Castleberry, S. B., W. M. Ford, P. B. Wood, N. L. Castleberry, and M. T. Mengak. 2001. Movements of Allegheny woodrats in relation to timber harvesting. Journal of Wildlife Management 65:148-156.

Chamblin, H. D., P. B. Wood, and J. W. Edwards. 2004. Allegheny woodrat (Neotoma magister) use of rock drainage channels on reclaimed mines in southern West Virginia. American Midland Naturalist 151:346-354.

Deston-Fearing Corporation. 1994. Mini portable reader MPR user manual. South St. Paul, Minnesota.

Gashwiler, J. S. 1979. Deer mouse reproduction and its relation to the tree seed crop. The American Midland Naturalist 102:95-104.

Greenwood, P. J. 1980. Mating systems, philopatry and dispersal in birds and mammals. Animal Behavior 28:1140-1162. 
Hicks, A. 1989. Whatever happened to the Allegheny woodrat? Pages 34-38 in The conservationist (March-April). New York State Dept. Environmental Conservation, Albany, New York.

James, F. C., and H. H. Shugart. 1970. A quantitative method of habitat description. Audubon Field Notes 24:727-736.

LoGiudice, K. 2003. Tropically transmitted parasites and the conservation of small populations: raccoon roundworm and the imperiled Allegheny woodrat. Conservation Biology 17:258266.

McMurry, S. T., R. L. Lochmiller, J. F. Boggs, D. M. Leslie, Jr., and D. M. Engle. 1993. Opportunistic foraging of Eastern woodrats (Neotoma floridana) in manipulated habitats. American Midland Naturalist 130:323-337.

Mengak, M. T. 1996. Status and distribution of woodrat populations in Virginia. Pages 2-3 in Abstracts of the 1996 Allegheny Woodrat Recovery Group Meeting, Ferrum College, Ferrum, Virginia. . 2002. Reproduction, juvenile growth and recapture rates of Allegheny woodrats (Neotoma magister) in Virginia. American Midland Naturalist 148:155-162.

Myers, R. T. 1997. Microhabitat and ecology of the Allegheny woodrat in northcentral West Virginia. M. S. Thesis, West Virginia University, Morgantown, West Virginia, 84 pp. Nelson, L. and F. W. Clark. 1972. Correction for sprung traps in catch/effort calculations of trapping results. Journal of Mammalogy 54:295-298.

Owen, S. F., J. W. Edwards, W. M. Ford, J. M. Crum, and P. B. Wood. 2004. Raccoon roundworm in raccoons in Central West Virginia. Northeastern Naturalist 11:137-142. 
Poole, E. L. 1940a. A life history sketch of the Allegheny woodrat. Journal of Mammalogy 21:249-270. . 1940b. The technical name of the Allegheny woodrat. Journal of Mammalogy 21:316318. . 1936. Notes on the young of the Allegheny woodrat. Journal of Mammalogy 17:22-26.

SAS Institute. 2001. SAS Institute, Cary, North Carolina.

Smyth, M. 1966. Winter breeding in woodland mice, Apodemus sylvaticus, and voles, Clethrionomys glareolus, and Microtus agrestis, near Oxford. The Journal of Animal Ecology 35:471-485.

Wolff, J. O. 1996. Population fluctuation of mast-eating rodents are correlated with production of acorns. Journal of Mammalogy 77:850-856. 
Table 1. Vegetative characteristics modified from James and Shugart (1970) and measured at Coopers Rock State Forest, West Virginia and Snake Hill Wildlife Management Area, West Virginia during summer 2002.

\begin{tabular}{|c|c|}
\hline Variable & Definition \\
\hline Slope & Percentage of vertical rise over horizontal distance at the plot center. \\
\hline Aspect & $\begin{array}{l}\text { Compass direction measured along gradient of slope at the plot } \\
\text { center. }\end{array}$ \\
\hline Canopy cover & $\begin{array}{l}\text { Percent overhead canopy }(>2 \mathrm{~m}) \text { based on ocular readings every } \\
2.26 \mathrm{~m} \text { along four, } 11.3 \mathrm{~m} \text { transects intersecting at the center of the } \\
\text { plot. }\end{array}$ \\
\hline Rock overstory & $\begin{array}{l}\text { Percent overhead rock based on ocular readings every } 2.26 \mathrm{~m} \text { along } \\
\text { four, } 11.3 \mathrm{~m} \text { transects intersecting at the center of the plot. }\end{array}$ \\
\hline Ground cover & $\begin{array}{l}\text { Percent ground cover }(<1 \mathrm{~m}) \text { based on ocular readings every } 2.26 \mathrm{~m} \\
\text { along four, } 11.3 \mathrm{~m} \text { transects intersecting at the center of the plot. }\end{array}$ \\
\hline Green & Grasses, forbes, shrubs, greenbrier (Smilax spp.), and moss species \\
\hline Fern & Fern species \\
\hline Woody debris & Downed coarse woody debris \\
\hline Non-cover & Leaf litter, bare ground, rock, and standing trees and roots \\
\hline Mature hard mast stem densities & Average number of hard mast $(\mathrm{HM})$ stems $>15 \mathrm{~cm} \mathrm{DBH}^{\mathrm{a}}$ per plot \\
\hline Soft mast stem densities & $\begin{array}{l}\text { Total number of soft mast (SM) shrub stems and trees stems }>8 \mathrm{~cm} \\
\text { DBH based on average number of stems per plot. }\end{array}$ \\
\hline Overall stem densities & $\begin{array}{l}\text { Total number of stems in each size category below based on average } \\
\text { number of stems per plot }\end{array}$ \\
\hline Shrubs & $<3 \mathrm{~cm} \mathrm{DBH}$ and $<2 \mathrm{~m}$ high \\
\hline Saplings & $<3 \mathrm{~cm} \mathrm{DBH}$ and $>2 \mathrm{~m}$ high \\
\hline Poles & $>3-8 \mathrm{~cm} \mathrm{DBH}$ \\
\hline Immature & $>8-15 \mathrm{~cm} \mathrm{DBH}$ \\
\hline Mature & $>15 \mathrm{~cm} \mathrm{DBH}$ \\
\hline
\end{tabular}


Table 2. Number of individual Allegheny woodrats captured each year ( $n$ ) adjusted per 100 trap night (CPUE) and the percent of total captures for that given year at Coopers Rock State Forest (CR), West Virginia University Research Forest (UF), and Snake Hill Wildlife Management Area $(\mathrm{SH})$ in West Virginia.

\begin{tabular}{|c|c|c|c|c|c|c|c|c|c|c|c|c|c|c|c|c|c|}
\hline \multirow{2}{*}{$\begin{array}{l}\text { Study } \\
\text { area }\end{array}$} & \multirow[b]{2}{*}{ Year } & \multirow{2}{*}{$\begin{array}{l}\text { Number } \\
\text { of sites }\end{array}$} & \multirow{2}{*}{$\begin{array}{l}\text { Number of } \\
\text { trap nights }\end{array}$} & \multicolumn{3}{|c|}{ Adult males } & \multicolumn{3}{|c|}{ Adult females } & \multicolumn{3}{|c|}{ Juvenile males } & \multicolumn{3}{|c|}{ Juvenile females } & \multicolumn{2}{|c|}{ Total } \\
\hline & & & & $n$ & CPUE & $\%$ & $n$ & CPUE & $\%$ & $n$ & CPUE & $\%$ & $n$ & CPUE & $\%$ & $n$ & CPUE \\
\hline \multirow[t]{9}{*}{ CR } & 1995 & 4 & 142.0 & 1 & 0.7 & 7.1 & 9 & 6.3 & 64.3 & 3 & 2.1 & 21.4 & 1 & 0.7 & 7.1 & 14 & 9.9 \\
\hline & 1996 & 14 & 1250.0 & 20 & 1.6 & 31.3 & 28 & 2.2 & 43.8 & 8 & 0.6 & 12.5 & 8 & 0.6 & 12.5 & 64 & 5.1 \\
\hline & 1997 & 6 & 426.0 & 14 & 3.3 & 35.9 & 22 & 5.2 & 56.4 & $1^{\mathrm{a}}$ & 0.2 & 2.6 & 2 & 0.5 & 5.1 & 39 & 9.2 \\
\hline & 1998 & 1 & 104.0 & 2 & 1.9 & 18.2 & 4 & 3.8 & 36.4 & 3 & 2.9 & 27.3 & 2 & 1.9 & 18.2 & 11 & 10.6 \\
\hline & 1999 & 15 & 1270.5 & 22 & 1.7 & 30.1 & 25 & 2.0 & 34.2 & 13 & 1.0 & 17.8 & $13^{\mathrm{b}}$ & 1.0 & 17.8 & 73 & 5.7 \\
\hline & 2000 & 19 & 1664.0 & 22 & 1.3 & 26.2 & 33 & 2.0 & 39.3 & 15 & 0.9 & 17.9 & 14 & 0.8 & 16.7 & 84 & 5.0 \\
\hline & 2001 & 10 & 524.5 & 17 & 3.2 & 47.2 & 13 & 2.5 & 36.1 & 2 & 0.4 & 5.6 & 4 & 0.8 & 11.1 & 36 & 6.9 \\
\hline & 2002 & 12 & 1294.5 & 28 & 2.2 & 37.3 & 21 & 1.6 & 28.0 & 10 & 0.8 & 13.3 & 16 & 1.2 & 21.3 & 75 & 5.8 \\
\hline & 2003 & 12 & 968.5 & 20 & 2.1 & 43.5 & 15 & 1.5 & 32.6 & 4 & 0.4 & 8.7 & 7 & 0.7 & 15.2 & 46 & 4.7 \\
\hline Mean & & 13.7 & 849.3 & 16.2 & 2.0 & 30.8 & 18.9 & 3.0 & 41.2 & 6.6 & 1.0 & 14.1 & 7.4 & 0.9 & 13.9 & 49.1 & 7.0 \\
\hline \multirow[t]{6}{*}{ UF } & 1995 & 5 & 309.0 & 3 & 1.0 & 33.3 & 4 & 1.3 & 44.4 & 0 & 0.0 & 0.0 & 2 & 0.6 & 22.2 & 9 & 2.9 \\
\hline & 1996 & 59 & 3137.0 & 14 & 0.4 & 29.8 & 18 & 0.6 & 38.3 & 6 & 0.2 & 12.8 & 9 & 0.3 & 19.1 & 47 & 1.5 \\
\hline & 1997 & 9 & 462.0 & 7 & 1.5 & 24.1 & 16 & 3.5 & 55.2 & 3 & 0.6 & 10.3 & 3 & 0.6 & 10.3 & 29 & 6.3 \\
\hline & 1998 & 5 & 124.0 & 1 & 0.8 & 33.3 & 2 & 1.6 & 66.7 & 0 & 0.0 & 0.0 & 0 & 0.0 & 0.0 & 3 & 2.4 \\
\hline & 2000 & 1 & 56.0 & 0 & 0.0 & 0.0 & 0 & 0.0 & 0.0 & 0 & 0.0 & 0.0 & 1 & 1.8 & 100.0 & 1 & 1.8 \\
\hline & 2002 & 3 & 81.0 & 1 & 1.2 & 33.3 & 1 & 1.2 & 33.3 & 0 & 0.0 & 0.0 & 1 & 1.2 & 33.3 & 3 & 3.7 \\
\hline Mean & & 21.0 & 694.8 & 4.3 & 0.8 & 25.7 & 6.8 & 1.4 & 39.7 & 1.5 & 0.1 & 3.9 & 2.7 & 0.8 & 30.8 & 15.3 & 3.1 \\
\hline \multirow[t]{5}{*}{$\mathrm{SH}$} & 1999 & 9 & 362.0 & 10 & 2.8 & 38.5 & 13 & 3.6 & 50.0 & 2 & 0.6 & 7.7 & 1 & 0.3 & 3.8 & 26 & 7.2 \\
\hline & 2000 & 10 & 491.0 & 11 & 2.2 & 39.3 & 12 & 2.4 & 42.9 & 2 & 0.4 & 7.1 & 3 & 0.6 & 10.7 & 28 & 5.7 \\
\hline & 2001 & 2 & 103.0 & 0 & 0.0 & 0.0 & 1 & 1.0 & 100.0 & 0 & 0.0 & 0.0 & 0 & 0.0 & 0.0 & 1 & 1.0 \\
\hline & 2002 & 3 & 402.5 & 6 & 1.5 & 37.5 & 4 & 1.0 & 25.0 & 3 & 0.7 & 18.8 & 3 & 0.7 & 18.8 & 16 & 4.0 \\
\hline & 2003 & 3 & 327.0 & 6 & 1.8 & 50.0 & 4 & 1.2 & 33.3 & 2 & 0.6 & 16.7 & 0 & 0.0 & 0.0 & 12 & 3.7 \\
\hline Mean & & 5.4 & 337.1 & 6.6 & 1.7 & 33.0 & 6.8 & 1.8 & 50.2 & 1.8 & 0.5 & 10.1 & 1.4 & 0.3 & 6.7 & 16.6 & 4.3 \\
\hline Overal & l Mean & 12.3 & 674.9 & 10.3 & 1.6 & 29.8 & 12.3 & 2.2 & 43.0 & 3.9 & 0.6 & 10.0 & 4.5 & 0.7 & 17.2 & 30.9 & 5.2 \\
\hline
\end{tabular}

${ }^{a}$ One and ${ }^{b}$ two captures where capture history was unknown and animals were removed prior to analyses 
Table 3. Number of individual Allegheny woodrats captured each year (n) and number and percentage of those captures that were recaptures from previous years at Coopers Rock State Forest (CR), West Virginia University Research Forest (UF), and Snake Hill Wildlife Management Area (SH) in West Virginia.

\begin{tabular}{|c|c|c|c|c|c|c|c|c|c|c|c|c|}
\hline \multirow{2}{*}{$\begin{array}{l}\text { Study } \\
\text { area }\end{array}$} & \multirow[b]{2}{*}{ Year } & \multirow{2}{*}{$\begin{array}{l}\text { Number } \\
\text { of sites }\end{array}$} & \multirow{2}{*}{$\begin{array}{l}\text { Number of } \\
\text { trap nights }\end{array}$} & \multicolumn{3}{|c|}{ Males } & \multicolumn{3}{|c|}{ Females } & \multicolumn{3}{|c|}{ Total } \\
\hline & & & & $n$ & recaps & $\%$ recaps & $n$ & recaps & $\%$ recaps & $n$ & recaps & $\%$ recaps \\
\hline \multirow[t]{9}{*}{$\overline{\mathrm{CR}}$} & 1995 & 4 & 142.0 & 1 & 0 & 0.0 & 9 & 0 & 0.0 & 14 & 0 & 0.0 \\
\hline & 1996 & 14 & 1250.0 & 20 & 1 & 5.0 & 28 & 6 & 21.4 & 64 & 7 & 10.9 \\
\hline & 1997 & 6 & 426.0 & 14 & 8 & 57.1 & 22 & 12 & 54.5 & 39 & 20 & 51.3 \\
\hline & 1998 & 1 & 104.0 & 2 & 1 & 50.0 & 4 & 0 & 0.0 & 11 & 1 & 9.1 \\
\hline & 1999 & 15 & 1270.5 & 22 & 3 & 13.6 & 26 & 9 & 34.6 & 73 & 12 & 16.4 \\
\hline & 2000 & 19 & 1664.0 & 22 & 8 & 36.4 & 33 & 19 & 57.6 & 84 & 27 & 32.1 \\
\hline & 2001 & 10 & 524.5 & 17 & 6 & 35.3 & 13 & 4 & 30.8 & 36 & 10 & 27.8 \\
\hline & 2002 & 12 & 1294.5 & 28 & 10 & 35.7 & 21 & 8 & 38.1 & 75 & 18 & 24.0 \\
\hline & 2003 & 12 & 968.5 & 20 & 6 & 30.0 & 15 & 11 & 73.3 & 46 & 17 & 37.0 \\
\hline Mean & & 10.3 & 849.3 & 16.2 & 4.8 & 32.9 & 19.0 & 7.7 & 38.8 & 53.5 & 14.0 & 26.1 \\
\hline \multirow[t]{6}{*}{$\overline{\mathrm{UF}}$} & 1995 & 5 & 309.0 & 3 & 0 & 0.0 & 4 & 0 & 0.0 & 9 & 0 & 0.0 \\
\hline & 1996 & 59 & 3137.0 & 14 & 0 & 0.0 & 18 & 3 & 16.7 & 47 & 3 & 6.4 \\
\hline & 1997 & 9 & 462.0 & 7 & 5 & 71.4 & 16 & 12 & 75.0 & 29 & 17 & 58.6 \\
\hline & 1998 & 5 & 124.0 & 1 & 0 & 0.0 & 2 & 1 & 50.0 & 3 & 1 & 33.3 \\
\hline & 2000 & 1 & 56.0 & 0 & 0 & 0.0 & 0 & 0 & 0.0 & 1 & 0 & 0.0 \\
\hline & 2002 & 3 & 81.0 & 1 & 0 & 0.0 & 1 & 0 & 0.0 & 3 & 0 & 0.0 \\
\hline Mean & & 13.7 & 694.8 & 4.3 & 0.8 & 14.3 & 6.8 & 2.7 & 28.3 & 16.6 & 4.2 & 19.7 \\
\hline \multirow[t]{5}{*}{$\mathrm{SH}$} & 1999 & 9 & 362.0 & 10 & 0 & 0.0 & 13 & 0 & 0.0 & 26 & 0 & 0.0 \\
\hline & 2000 & 10 & 491.0 & 11 & 3 & 27.3 & 12 & 4 & 33.3 & 28 & 7 & 25.0 \\
\hline & 2001 & 2 & 103.0 & 0 & 0 & 0.0 & 1 & 0 & 0.0 & 1 & 0 & 0.0 \\
\hline & 2002 & 3 & 402.5 & 6 & 2 & 33.3 & 4 & 0 & 0.0 & 16 & 2 & 12.5 \\
\hline & 2003 & 3 & 327.0 & 6 & 2 & 33.3 & 4 & 3 & 75.0 & 12 & 5 & 41.7 \\
\hline Mean & & 5.4 & 337.1 & 6.6 & 1.4 & 23.5 & 6.8 & 1.4 & 27.1 & 14.3 & 3.5 & 19.8 \\
\hline Overal & Mean & 10.1 & 674.9 & 10.3 & 2.8 & 25.2 & 12.3 & 4.6 & 33.0 & 33.4 & 8.6 & 22.7 \\
\hline
\end{tabular}


Table 4. ANOVA results for adult male, adult female, juvenile captures and all captures combined from all three study areas between 1995-2003.

\begin{tabular}{|c|c|c|c|c|c|c|c|c|}
\hline \multirow[b]{2}{*}{ Source } & \multicolumn{2}{|c|}{ Adult males } & \multicolumn{2}{|c|}{ Adult females } & \multicolumn{2}{|c|}{ Juveniles } & \multicolumn{2}{|c|}{ All captures } \\
\hline & $\mathrm{F}$ & $P$ & $\mathrm{~F}$ & $P$ & $\mathrm{~F}$ & $P$ & $\mathrm{~F}$ & $P$ \\
\hline Study area & 0.87 & 0.4395 & 1.39 & 0.2804 & 0.55 & 0.5916 & 1.01 & 0.3894 \\
\hline Year & 0.26 & 0.6203 & 7.48 & 0.0161 & 0.00 & 0.9477 & 3.04 & 0.1034 \\
\hline Study area*year & 0.87 & 0.4388 & 1.39 & 0.2819 & 0.54 & 0.5930 & 1.00 & 0.3912 \\
\hline
\end{tabular}

Table 5. ANOVA results for adult male, adult female, juvenile captures and all captures combined from specific sites trapped $\geq 4$ years at SH and CR between 1999-2003.

\begin{tabular}{|c|c|c|c|c|c|c|c|c|}
\hline \multirow[b]{2}{*}{ Source } & \multicolumn{2}{|c|}{ Adult males } & \multicolumn{2}{|c|}{ Adult females } & \multicolumn{2}{|c|}{ Juveniles } & \multicolumn{2}{|c|}{ All captures } \\
\hline & $\mathrm{F}$ & $P$ & $\mathrm{~F}$ & $P$ & $\mathrm{~F}$ & $P$ & $\mathrm{~F}$ & $P$ \\
\hline Study area & 1.00 & 0.3560 & 4.12 & 0.0887 & 0.66 & 0.4461 & 2.14 & 0.1939 \\
\hline Year & 0.83 & 0.3972 & 14.72 & 0.0086 & 1.68 & 0.2424 & 4.69 & 0.0736 \\
\hline Study area*year & 1.00 & 0.3559 & 4.12 & 0.0887 & 0.66 & 0.4470 & 2.14 & 0.1939 \\
\hline
\end{tabular}

Table 6. ANOVA results for adult male, adult female, juvenile captures and all captures combined from 13 specific rock outcrops trapped $\geq 4$ years at SH and CR between 1999-2003.

\begin{tabular}{|c|c|c|c|c|c|c|c|c|}
\hline \multirow[b]{2}{*}{ Source } & \multicolumn{2}{|c|}{ Adult males } & \multicolumn{2}{|c|}{ Adult females } & \multicolumn{2}{|c|}{ Juveniles } & \multicolumn{2}{|c|}{ All captures } \\
\hline & $\mathrm{F}$ & $P$ & $\mathrm{~F}$ & $P$ & $\mathrm{~F}$ & $P$ & $\mathrm{~F}$ & $P$ \\
\hline Outcrop & 0.41 & 0.9485 & 2.43 & 0.0216 & 2.10 & 0.0452 & 2.67 & 0.0127 \\
\hline Year & 0.56 & 0.4601 & 15.73 & 0.0004 & 4.30 & 0.0460 & 15.82 & 0.0004 \\
\hline Outcrop*year & 0.41 & 0.9488 & 2.43 & 0.0218 & 2.10 & 0.0454 & 2.67 & 0.0128 \\
\hline
\end{tabular}


Table 7. Average vegetative characteristics measured at 68 plots within Coopers Rock State Forest, West Virginia and 21 plots at Snake Hill Wildlife Management Area, West Virginia in August 2002.

\begin{tabular}{|c|c|c|c|c|c|c|c|c|c|c|}
\hline \multirow[b]{2}{*}{ Variable } & \multicolumn{4}{|c|}{$\begin{array}{l}\text { Coopers Rock State Forest } \\
\qquad(n=68)\end{array}$} & \multicolumn{4}{|c|}{$\begin{array}{c}\text { Snake Hill Wildlife } \\
\text { Management Area }(n=21)\end{array}$} & \multirow[b]{2}{*}{$t$} & \multirow[b]{2}{*}{$P$} \\
\hline & Mean & $\mathrm{SE}$ & Min & Max & Mean & SE & Min & Max & & \\
\hline Slope (\%) & 32.8 & 1.9 & 2.0 & 66.0 & 47.0 & 4.6 & 20.0 & 100.0 & -3.37 & 0.0011 \\
\hline $\operatorname{Aspect}\left({ }^{\circ}\right)^{\mathrm{a}}$ & 1.2 & 0.1 & 0.0 & 2.0 & 1.2 & 0.2 & 0.1 & 2.0 & -0.80 & 0.9345 \\
\hline Canopy cover (\%) & 81.3 & 1.2 & 55.0 & 100.0 & 86.0 & 1.7 & 65.0 & 95.0 & -1.98 & 0.0512 \\
\hline Rock overstory (\%) & 3.2 & 0.8 & 0.0 & 30.0 & 2.4 & 1.1 & 0.0 & 20.0 & 0.57 & 0.5691 \\
\hline \multicolumn{11}{|l|}{ Ground cover $(\%)$} \\
\hline Green & 5.9 & 1.1 & 0.0 & 45.0 & 22.6 & 3.7 & 0.0 & 55.0 & -4.32 & 0.0002 \\
\hline Fern & 8.2 & 1.7 & 0.0 & 65.0 & 7.9 & 1.3 & 0.0 & 20.0 & 0.14 & 0.8869 \\
\hline Woody debris & 9.9 & 0.9 & 0.0 & 30.0 & 4.5 & 1.2 & 0.0 & 20.0 & 3.13 & 0.0024 \\
\hline Non-cover & 76.1 & 2.0 & 20.0 & 100.0 & 65.0 & 3.8 & 30.0 & 95.0 & 2.66 & 0.0094 \\
\hline Mature hard mast stem densities & 5.1 & 0.4 & 0.0 & 14.0 & 3.8 & 0.6 & 0.0 & 9.0 & 1.50 & 0.1373 \\
\hline Soft mast stem densities & 3.9 & 0.5 & 0.0 & 12.0 & 1.5 & 0.4 & 0.0 & 4.7 & 3.64 & 0.0003 \\
\hline \multicolumn{11}{|l|}{ Overall stem densities } \\
\hline Shrub & 9.9 & 1.0 & 0.0 & 29.0 & 21.3 & 1.8 & 0.0 & 41.0 & -5.47 & $<0.0001$ \\
\hline Sapling & 4.5 & 0.7 & 0.0 & 35.0 & 9.7 & 1.6 & 0.0 & 26.0 & -2.98 & $<0.0001$ \\
\hline Pole & 2.8 & 0.3 & 0.0 & 13.0 & 6.1 & 0.7 & 0.0 & 15.0 & -4.05 & 0.0001 \\
\hline Immature & 3.5 & 0.3 & 0.0 & 9.0 & 6.6 & 1.0 & 0.0 & 21.0 & -3.05 & 0.0032 \\
\hline Mature & 12.1 & 0.7 & 0.0 & 22.0 & 11.2 & 1.0 & 0.0 & 15.0 & 0.71 & 0.4791 \\
\hline
\end{tabular}

${ }^{\mathrm{a}}$ Beers transformation performed on aspect prior to analysis $(\cos [45-\mathrm{x}]+1)($ Beers et al. 1966) 
Table 8. Pearson correlation coefficients for seasonal weather variables. Results were considered significant at $P<0.05$.

\begin{tabular}{|c|c|c|c|c|c|c|c|c|}
\hline \multirow[b]{2}{*}{ Weather variable } & \multicolumn{2}{|c|}{ Adult males } & \multicolumn{2}{|c|}{ Adult females $^{\mathrm{d}}$} & \multicolumn{2}{|c|}{ Juveniles } & \multicolumn{2}{|c|}{ All captures } \\
\hline & $r$ & $P$ & $r$ & $P$ & $r$ & $P$ & $r$ & $P$ \\
\hline \multicolumn{9}{|c|}{ Maximum temperature } \\
\hline Winter $^{\mathrm{a}}$ & 0.02 & 0.968 & 0.16 & 0.674 & 0.66 & 0.053 & 0.32 & 0.396 \\
\hline Spring $^{\mathrm{b}}$ & 0.10 & 0.791 & -0.50 & 0.170 & 0.39 & 0.304 & -0.25 & 0.515 \\
\hline Summer $^{\mathrm{c}}$ & 0.03 & 0.949 & 0.15 & 0.703 & 0.55 & 0.129 & 0.21 & 0.593 \\
\hline \multicolumn{9}{|c|}{ Minimum temperature } \\
\hline Winter $^{d}$ & 0.12 & 0.762 & -0.25 & 0.521 & -0.85 & 0.004 & -0.37 & 0.322 \\
\hline Spring & -0.40 & 0.288 & -0.22 & 0.567 & 0.59 & 0.097 & -0.23 & 0.544 \\
\hline Summer & -0.80 & 0.009 & -0.33 & 0.932 & 0.39 & 0.299 & -0.25 & 0.505 \\
\hline \multicolumn{9}{|c|}{ Average temperature } \\
\hline Winter & -0.05 & 0.903 & 0.24 & 0.535 & 0.76 & 0.016 & 0.37 & 0.327 \\
\hline Spring & -0.22 & 0.562 & -0.53 & 0.145 & 0.57 & 0.109 & -0.35 & 0.347 \\
\hline Summer & -0.64 & 0.063 & -0.12 & 0.749 & 0.51 & 0.159 & -0.24 & 0.531 \\
\hline \multicolumn{9}{|c|}{ Average rainfall $(\mathrm{cm})$} \\
\hline Winter $^{\mathrm{d}}$ & 0.04 & 0.922 & -0.49 & 0.184 & 0.35 & 0.350 & -0.24 & 0.538 \\
\hline Spring $^{\mathrm{d}}$ & 0.18 & 0.642 & -0.54 & 0.134 & -0.11 & 0.771 & -0.38 & 0.308 \\
\hline Summer ${ }^{\mathrm{d}}$ & 0.34 & 0.367 & -0.75 & 0.020 & -0.17 & 0.668 & -0.45 & 0.227 \\
\hline \multicolumn{9}{|c|}{ Average snowfall $(\mathrm{cm})$} \\
\hline Winter $^{\mathrm{d}}$ & 0.03 & 0.944 & -0.45 & 0.224 & -0.37 & 0.331 & -0.42 & 0.258 \\
\hline Spring $^{\mathrm{d}}$ & 0.35 & 0.351 & 0.08 & 0.847 & -0.67 & 0.048 & 0.04 & 0.920 \\
\hline Summer & $\mathrm{N} / \mathrm{A}$ & N/A & $\mathrm{N} / \mathrm{A}$ & N/A & $\mathrm{N} / \mathrm{A}$ & $\mathrm{N} / \mathrm{A}$ & $\mathrm{N} / \mathrm{A}$ & $\mathrm{N} / \mathrm{A}$ \\
\hline
\end{tabular}

${ }^{a}$ Winter months were November-December of the previous year and January-March of the current year

${ }^{\mathrm{b}}$ Spring months were April and May

'Summer months were June through October

${ }^{\mathrm{d}}$ These variables did not meet the assumptions of normality and were log transformed prior to correlation analyses 
a. $\mathrm{AM}(r=0.35, P=0.35)$; $\mathrm{AF}(r=-0.75, P=0.02) ; \mathrm{Juv}(r=-0.22, P=0.56) ;$ All $(r=-0.58, P=0.10)$

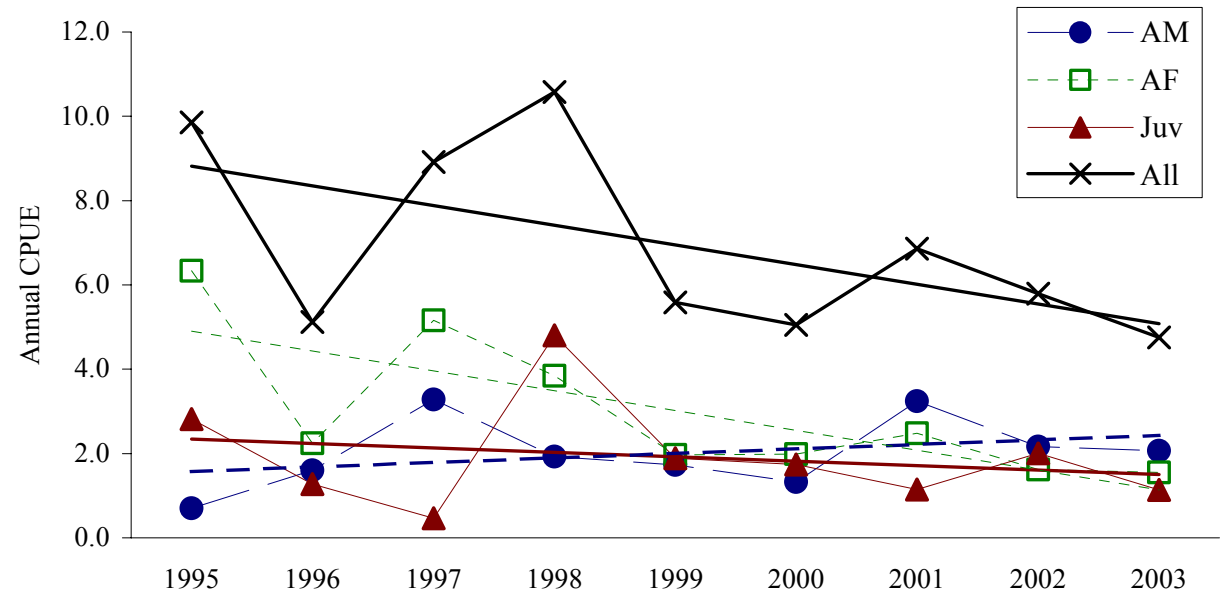

b. $\mathrm{AM}(r=-0.05, P=0.92) ; \mathrm{AF}(r=-0.23, P=0.66) ; \mathrm{Juv}(r=0.51, P=0.30) ;$ All $(r=0.02, P=0.98)$

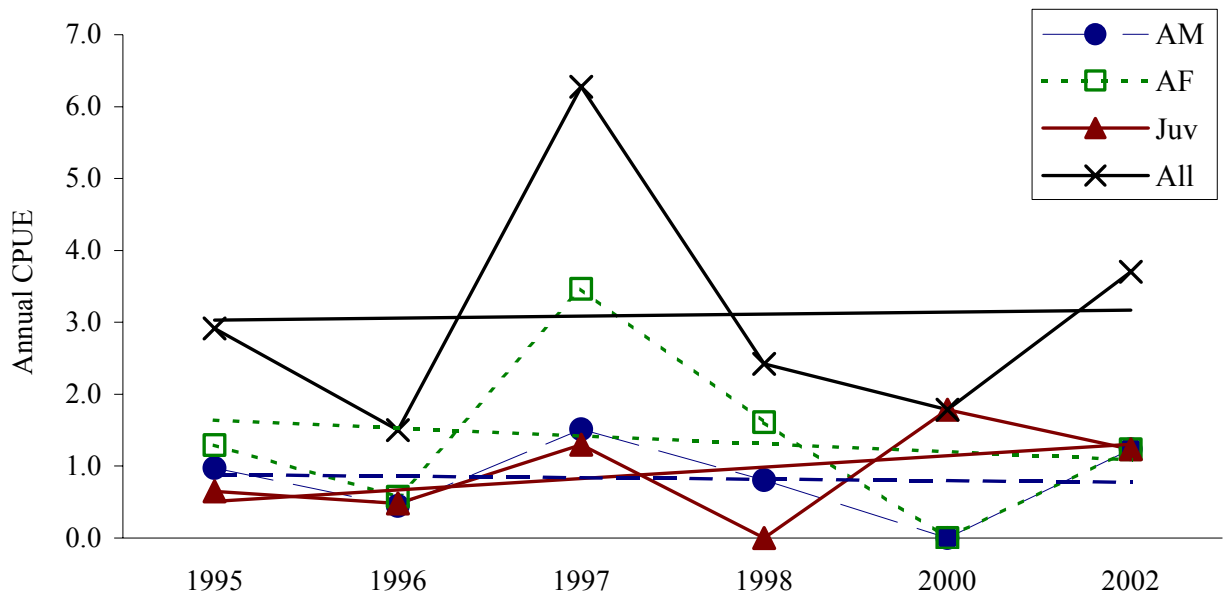

c. $\operatorname{AM}(r=-0.39, P=0.51) ; \mathrm{AF}(r=-0.85, P=0.07) ; \operatorname{Juv}(r=0.01, P=0.99) ; \operatorname{All}(r=-0.59, P=0.29)$

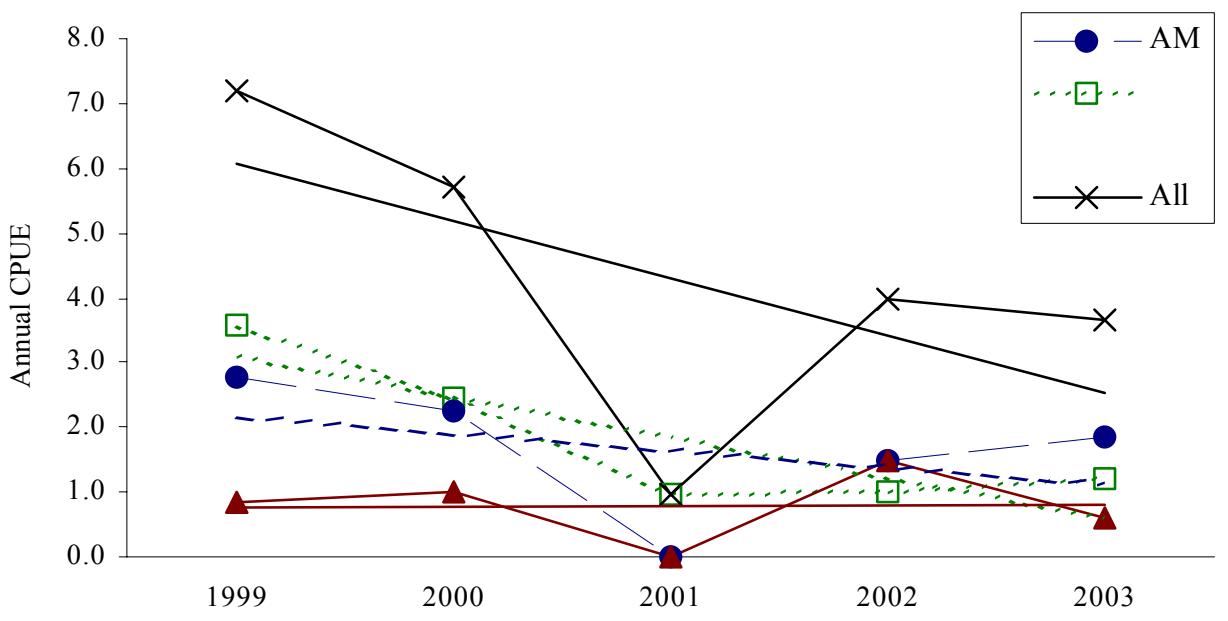

Figure 1. Annual adult male (AM), adult female (AF), and juvenile (Juv) captures adjusted per 100 trap nights (CPUE) at Coopers Rock State Forest (a), West Virginia University Forest (b), and Snake Hill Wildlife Management Area (c) in West Virginia. 
a. $\operatorname{AM}(r=0.05, P=0.93) ; \operatorname{AF}(r=-0.90, P=0.04) ; \operatorname{Juv}(r=-0.74, P=0.16) ;$ All $(r=-0.87, P=0.05)$

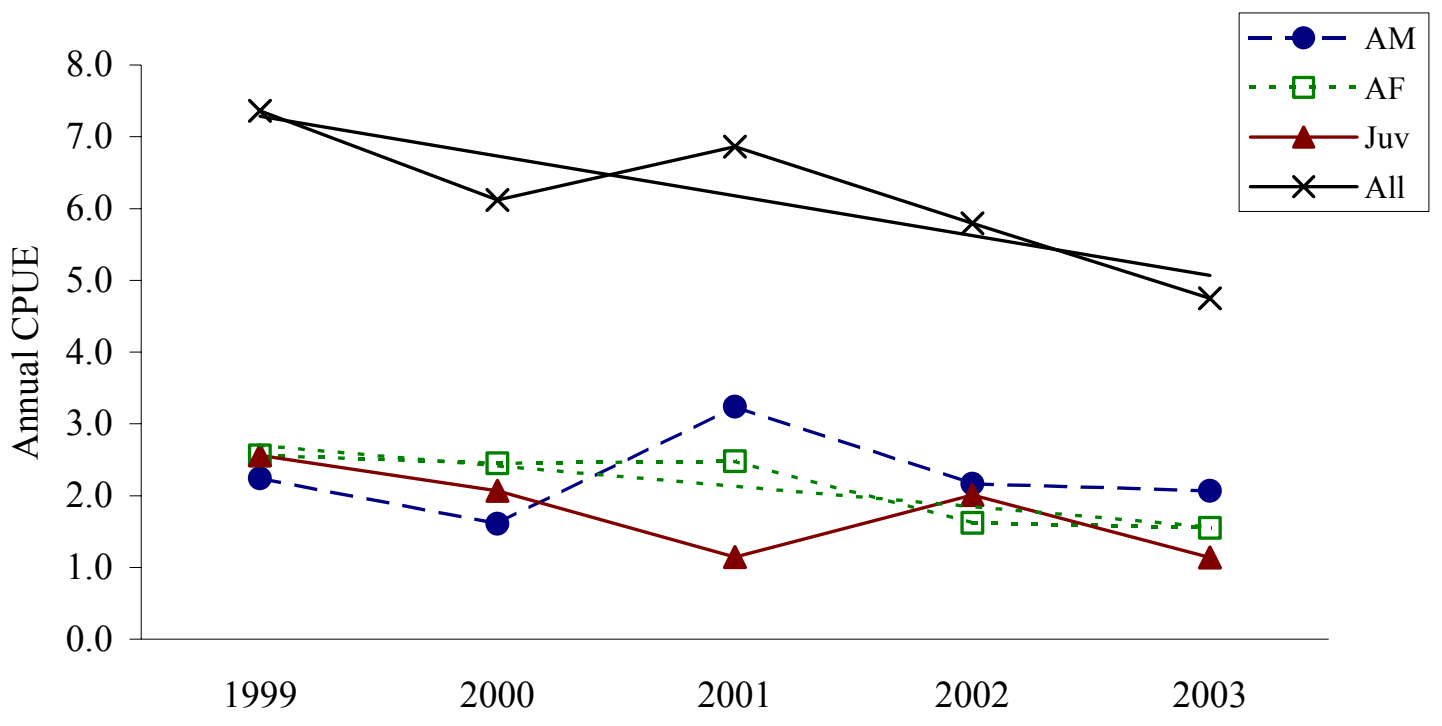

b. $\mathrm{AM}(r=-0.53, P=0.36)$; $\mathrm{AF}(r=-0.87, P=0.06) ; \mathrm{Juv}(r=-0.17, P=0.79) ;$ All $(r=-0.70, P=0.19)$

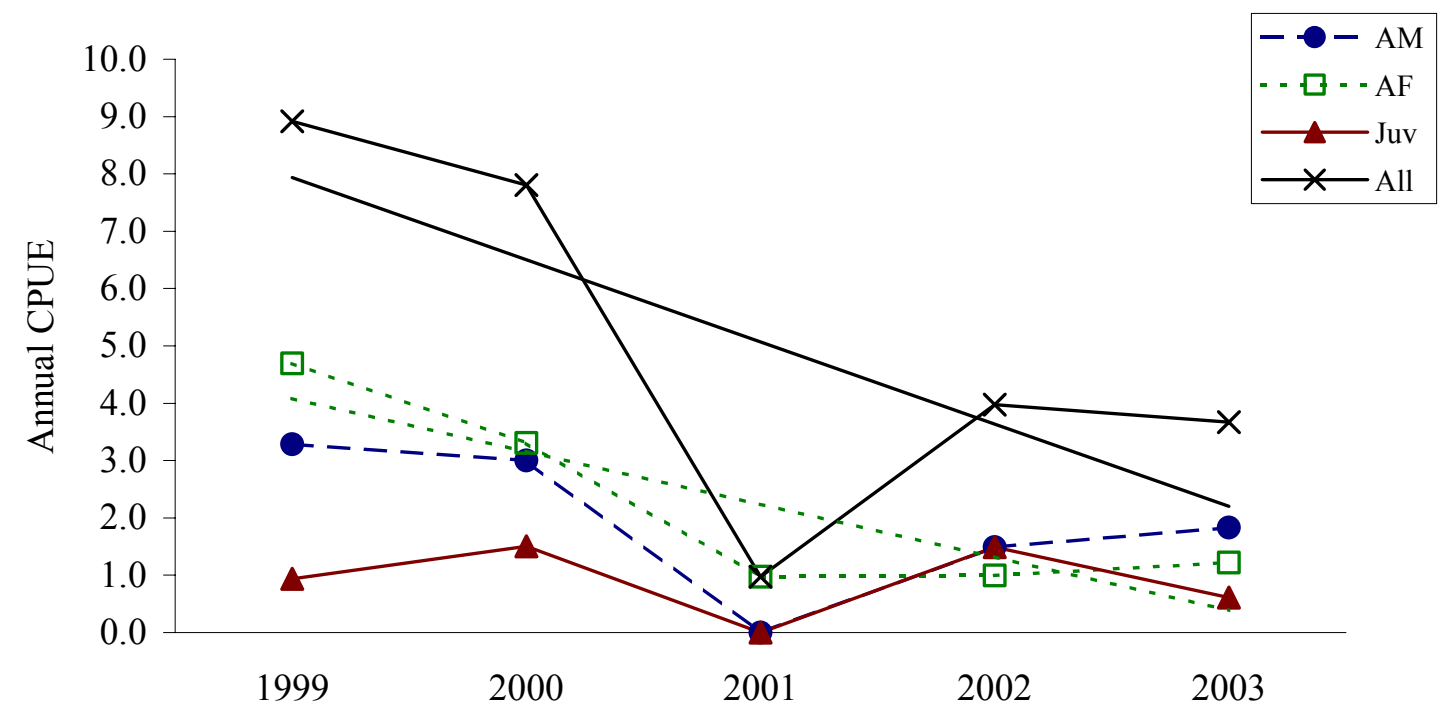

Figure 2. Annual adult male (AM), adult female (AF), and juvenile (Juv) captures between 1999 and 2003 adjusted per 100 trap nights (CPUE) at Coopers Rock State Forest (a) and Snake Hill Wildlife Management Area (b) in West Virginia. 


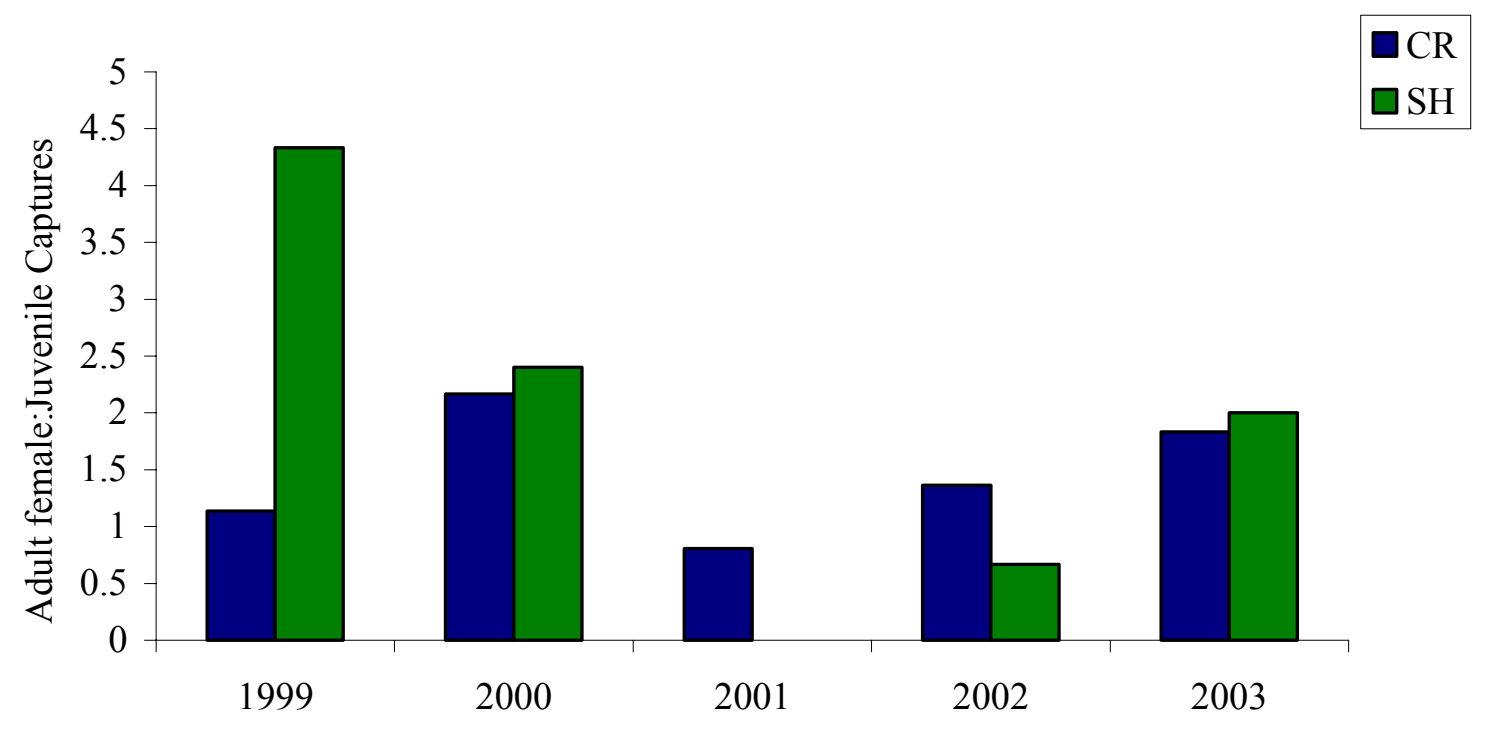

Figure 3. Annual adult female to juvenile ratio between 1999 and 2003 adjusted per 100 trap nights (CPUE) at Coopers Rock State Forest (CR, $r=-0.41, P=0.49$ ) and Snake Hill Wildlife Management Area $(\mathrm{SH}, r=-0.77, P=0.22)$ in West Virginia. 
a. $\quad \mathrm{CR}(r=-0.06, P=0.88)$; UF $(r=0.05, P=0.91)$; SH $(r=-0.49, P=0.41)$; All $(r=-0.0001, P=0.98)$

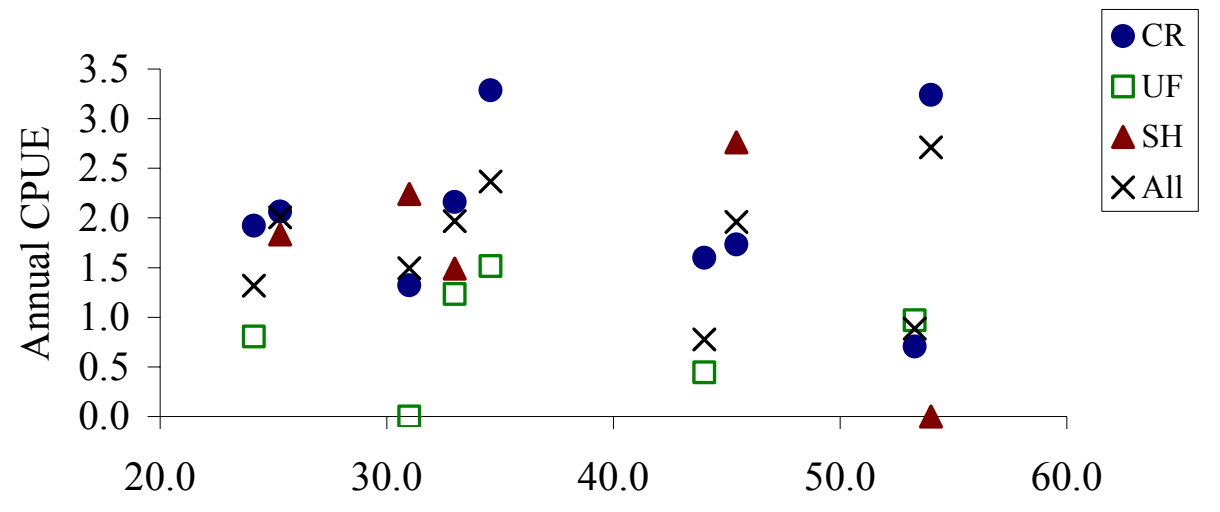

Hard mast index (\%)

b. $\mathrm{CR}(r=0.28, P=0.46)$; UF $(r=-0.10, P=0.85)$; $\mathrm{SH}(r=-0.13, P=0.84)$; All $(r=0.0046, P=0.86)$

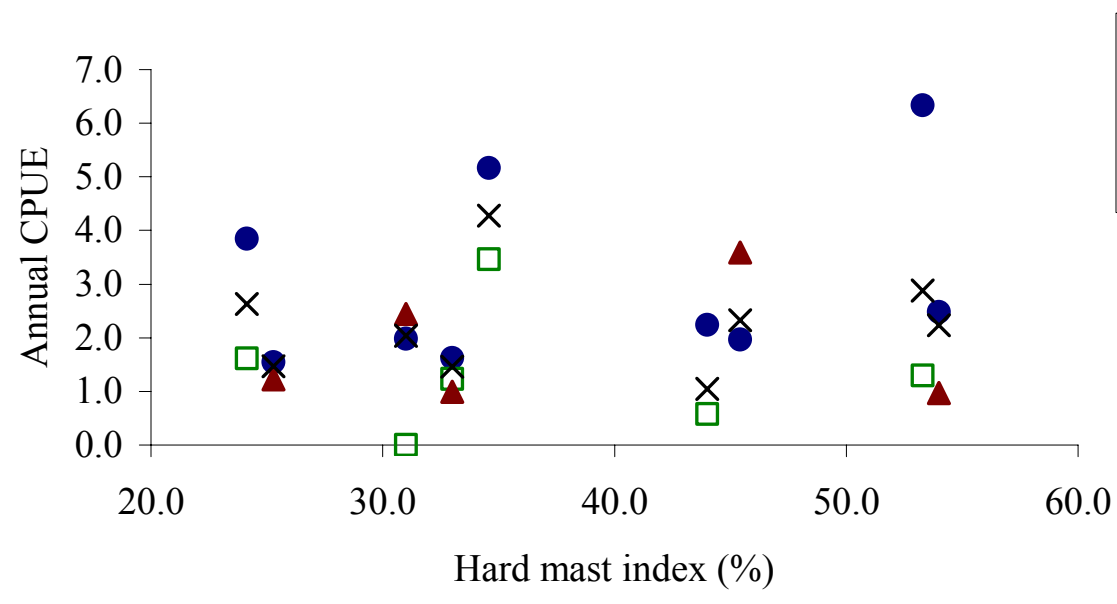

c. $\quad \mathrm{CR}(r=-0.23, P=0.54)$; UF $(r=-0.09, P=0.86)$; SH $(r=-0.59, P=0.29)$; All $(r=-0.16, P=0.29)$

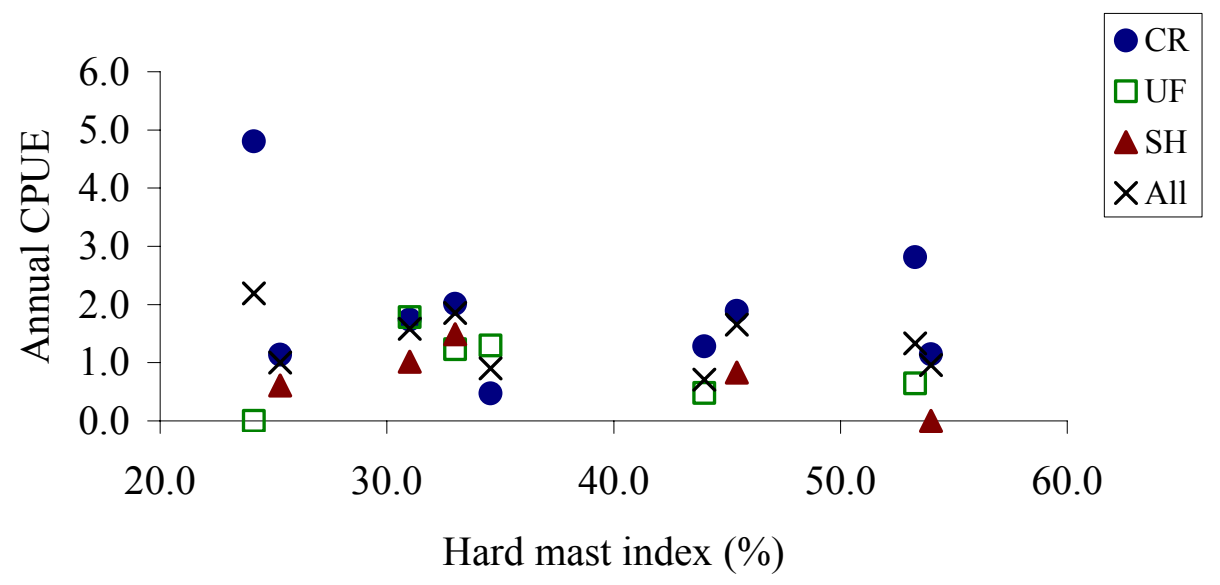

Figure 4. Annual adult male (a), adult female (b), and juvenile (c) captures adjusted per 100 trap nights (CPUE) at Coopers Rock State Forest (CR), West Virginia University Forest (UF), and Snake Hill Wildlife Management Area (SH) in West Virginia compared with the previous fall's hard mast index. 
a. $\quad \mathrm{CR}(r=-0.11, P=0.77) ; \mathrm{UF}(r=-0.11, P=0.84) ; \mathrm{SH}(r=0.58, P=0.31) ;$ All $(r=0.55, P=0.54)$

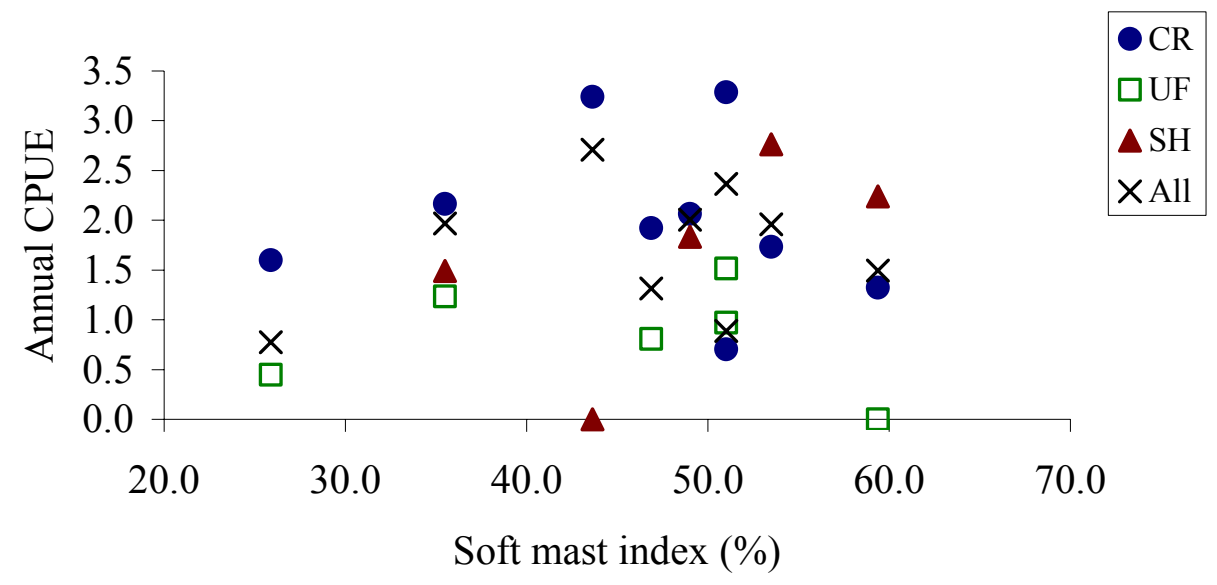

b. $\mathrm{CR}(r=0.24, P=0.53)$; UF $(r=0.13, P=0.81)$; $\mathrm{SH}(r=0.72, P=0.17) ;$ All $(r=0.29, P=0.14)$

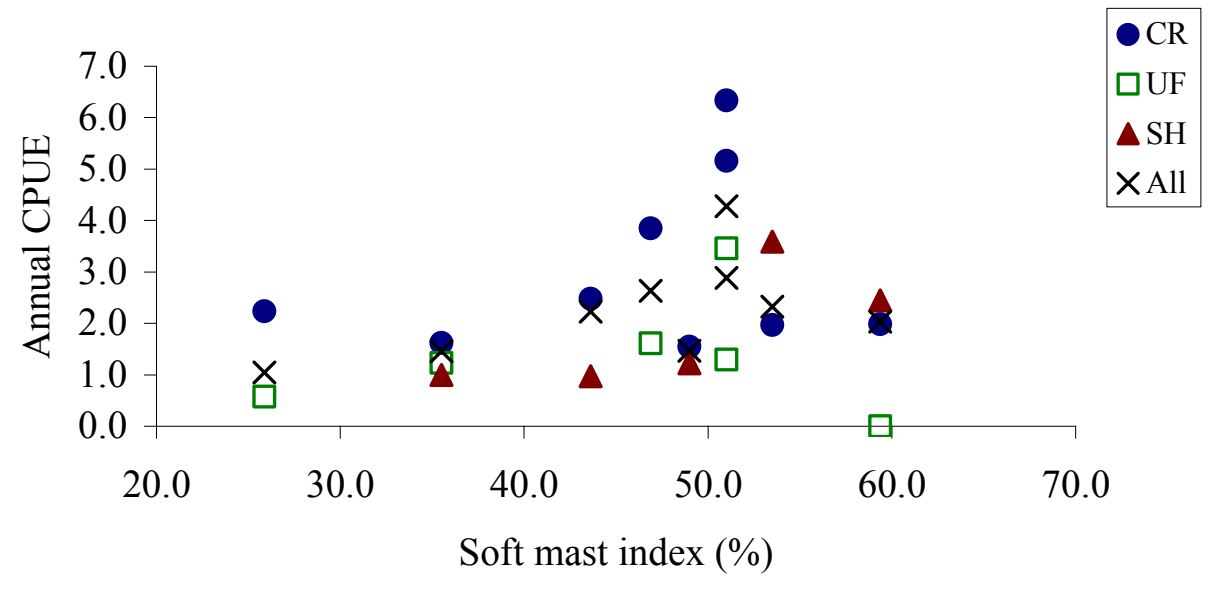

c. $\quad \mathrm{CR}(r=0.08, P=0.83)$; UF $(r=0.43, P=0.40)$; SH $(r=-0.13, P=0.83) ;$ All $(r=0.08, P=0.47)$

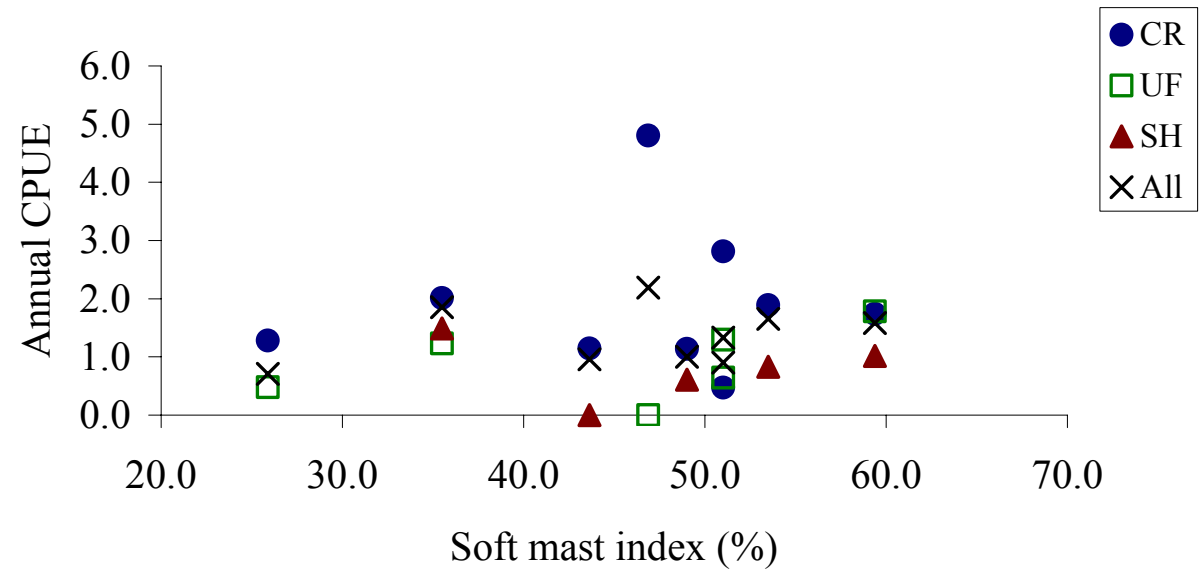

Figure 5. Annual adult male (a), adult female (b), and juvenile (c) captures adjusted per 100 trap nights (CPUE) at Coopers Rock State Forest (CR), West Virginia University Forest (UF), and Snake Hill Wildlife Management Area (SH) in West Virginia compared with the current year's soft mast index. 


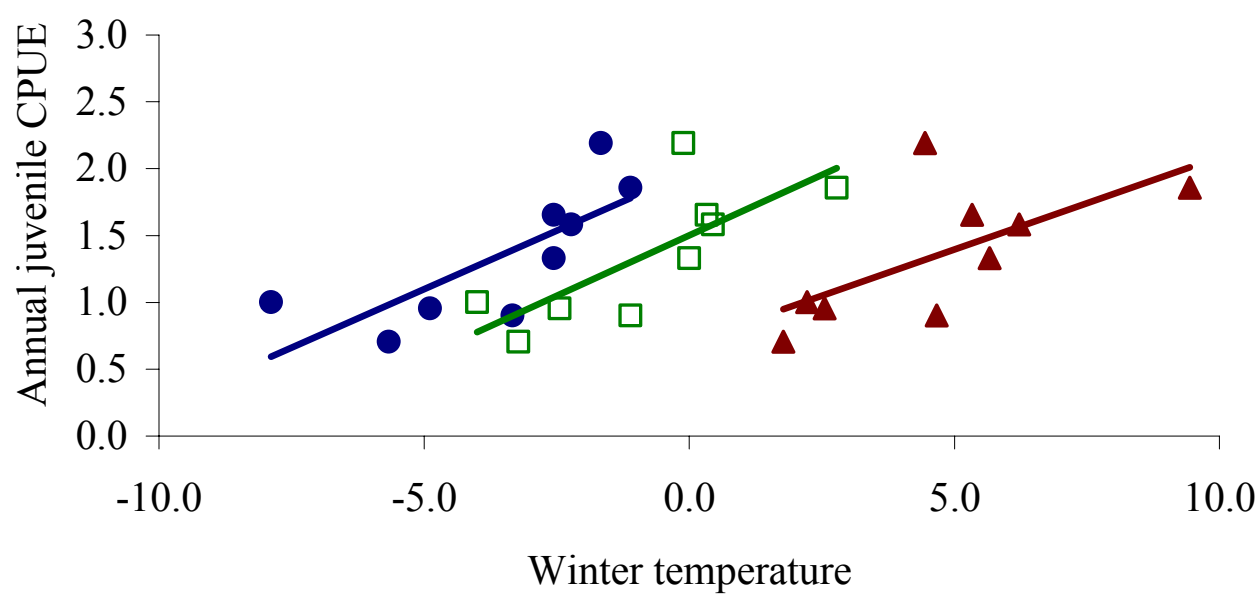

Minimum $\square$ Average

$\Delta$ Maximum

Winter temperature

Figure 6. Annual juvenile captures at all study sites in West Virginia adjusted per 100 trap nights (CPUE) and average winter temperature $\left({ }^{\circ} \mathrm{C}\right)$ for minimum winter temperature $(r=-0.85, P=$ $0.004)$, overall winter temperature $(r=0.76, P=0.02)$, and maximum winter temperature $(r=$ $0.66, P=0.05)$. Values plotted are untransformed data.

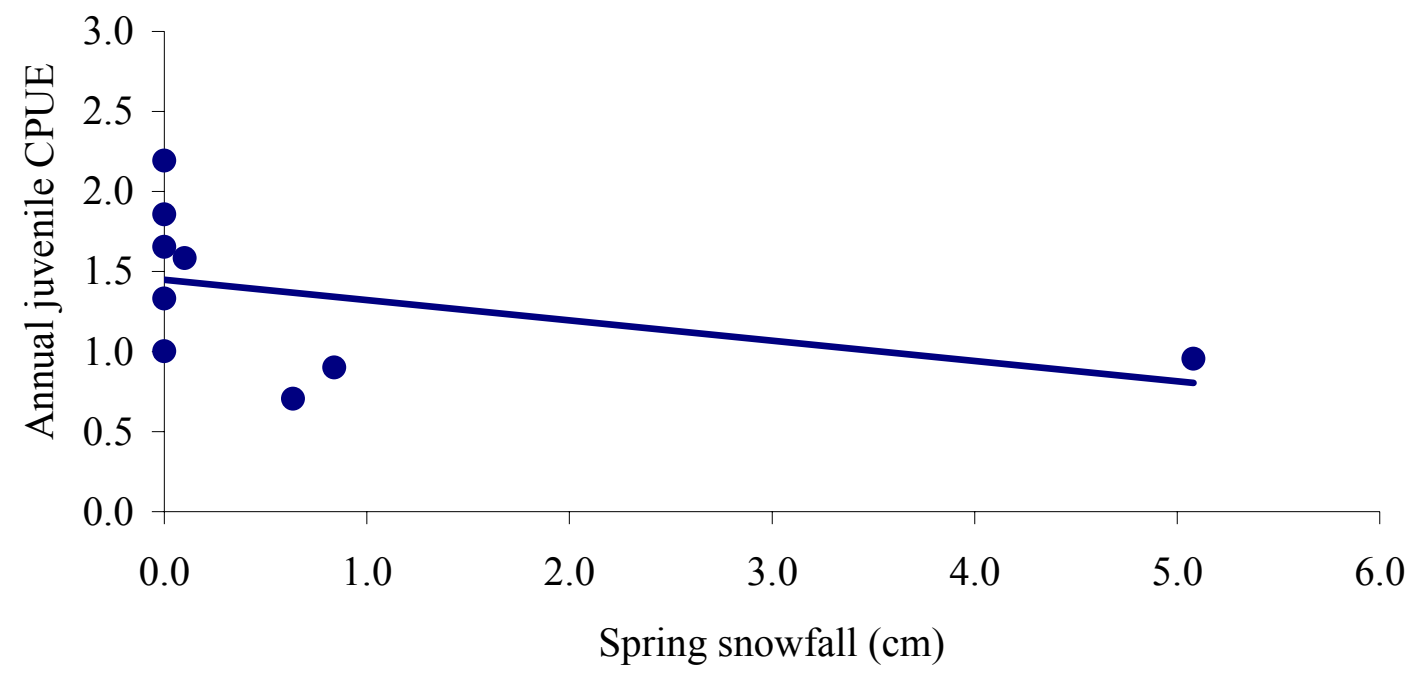

Figure 7. Annual juvenile captures at all study sites in West Virginia adjusted per 100 trap nights (CPUE) and average spring snowfall $(\mathrm{cm})(r=-0.67, P=0.05)$. Values plotted are untransformed data. 


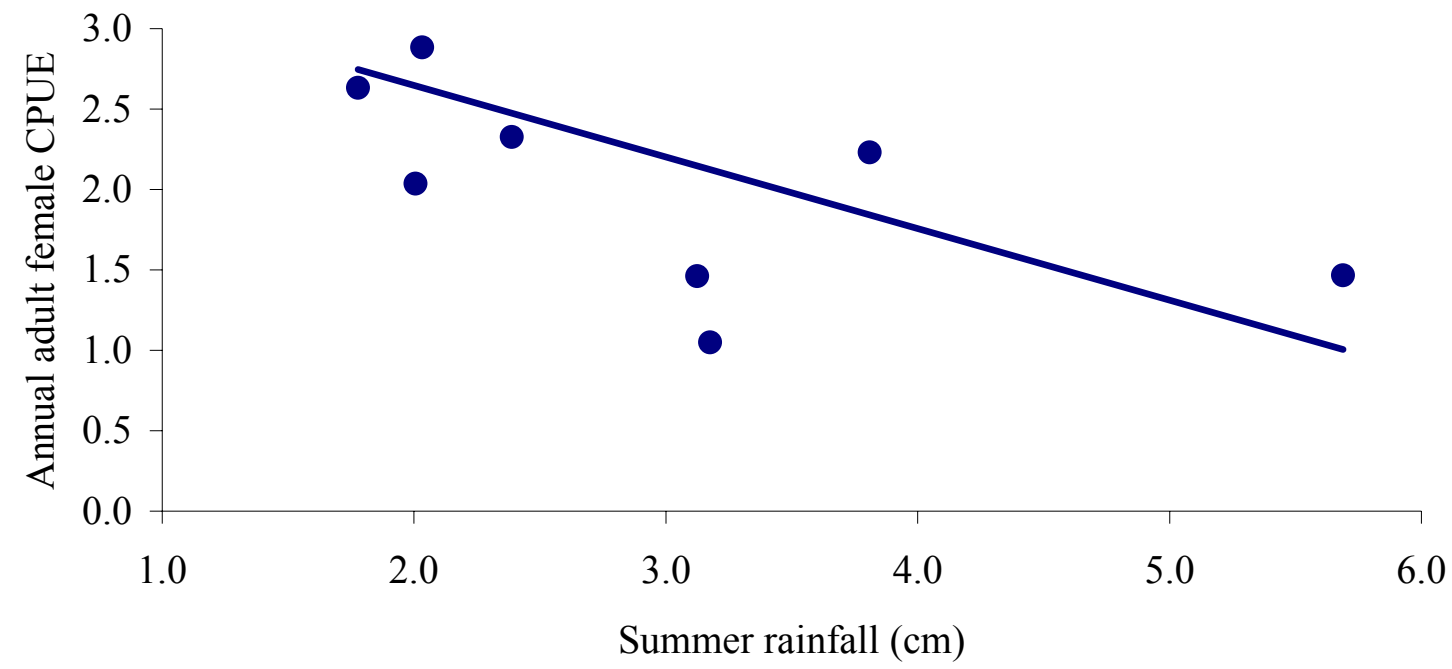

Figure 8. Annual adult female captures at all study sites in West Virginia adjusted per 100 trap nights (CPUE) and average summer rainfall $(\mathrm{cm})(r=-0.75, P=0.02)$. Values plotted are untransformed data.

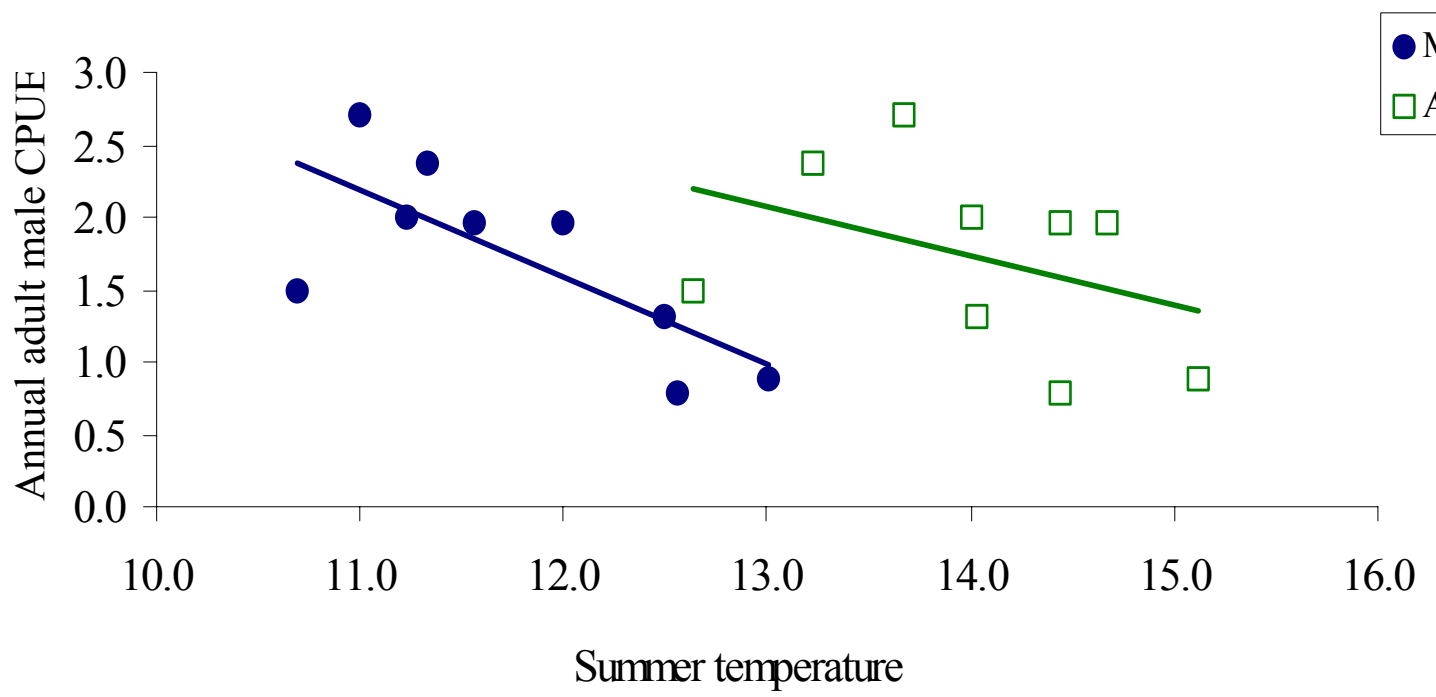

Figure 9. Annual adult male captures at all study sites in West Virginia adjusted per 100 trap nights (CPUE) compared to minimum $(r=-0.80, P=0.01)$ and average $(r=-0.64, P=0.06)$ summer temperature $\left({ }^{\circ} \mathrm{C}\right)$. 


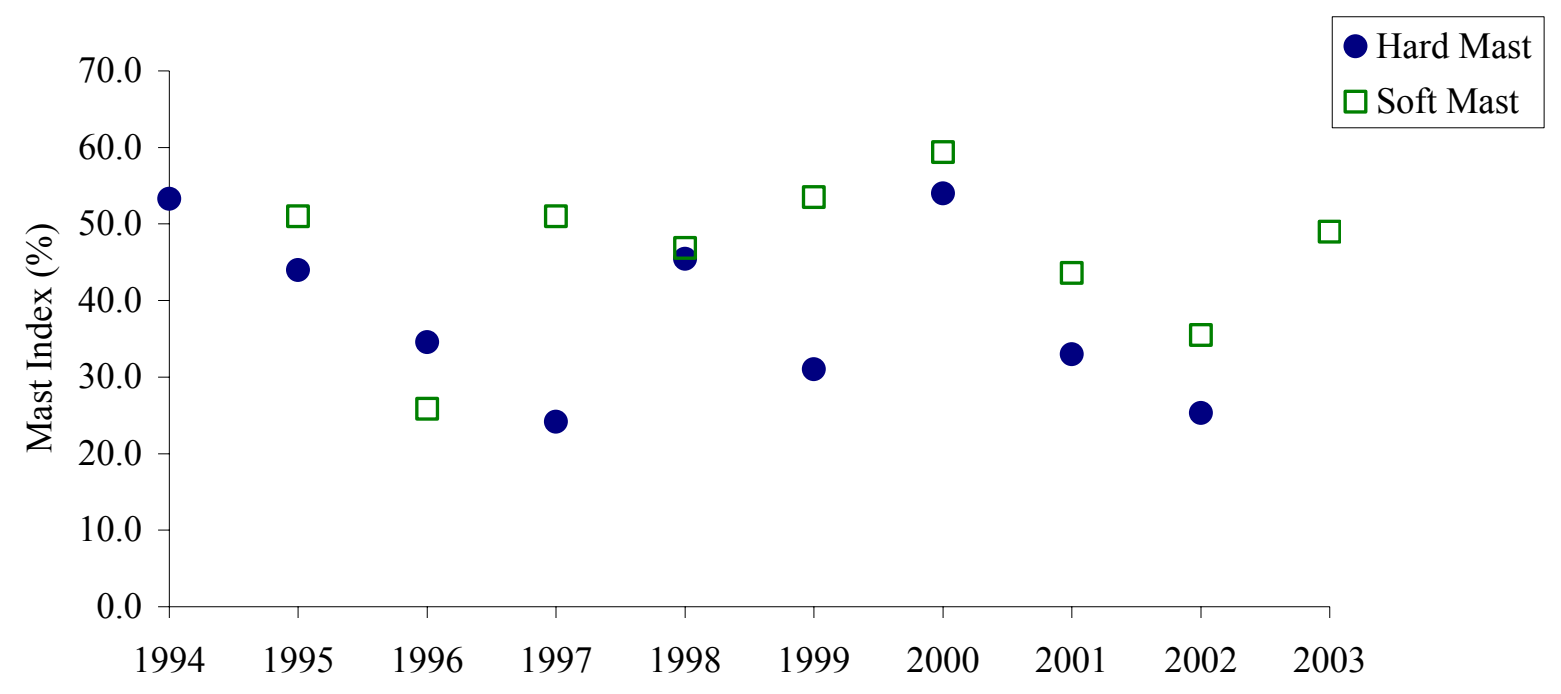

Figure 10. Yearly mast indexes (\%) calculated by West Virginia Division of Natural Resources in northcentral West Virginia.

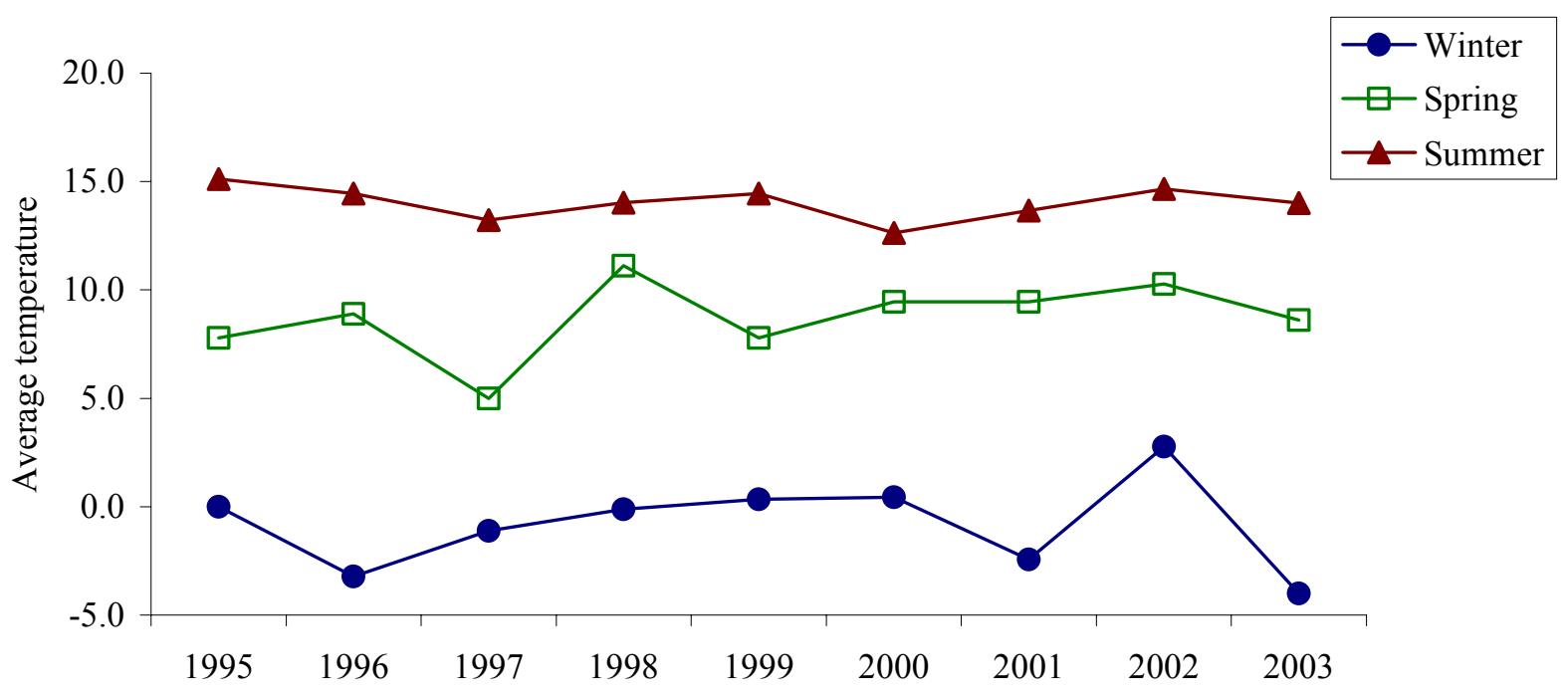

Figure 11. Seasonal yearly average temperatures $\left({ }^{\circ} \mathrm{C}\right)$ from the Coopers Rock Weather Station located in the West Virginia University Research Forest, West Virginia, 1995-2003. 


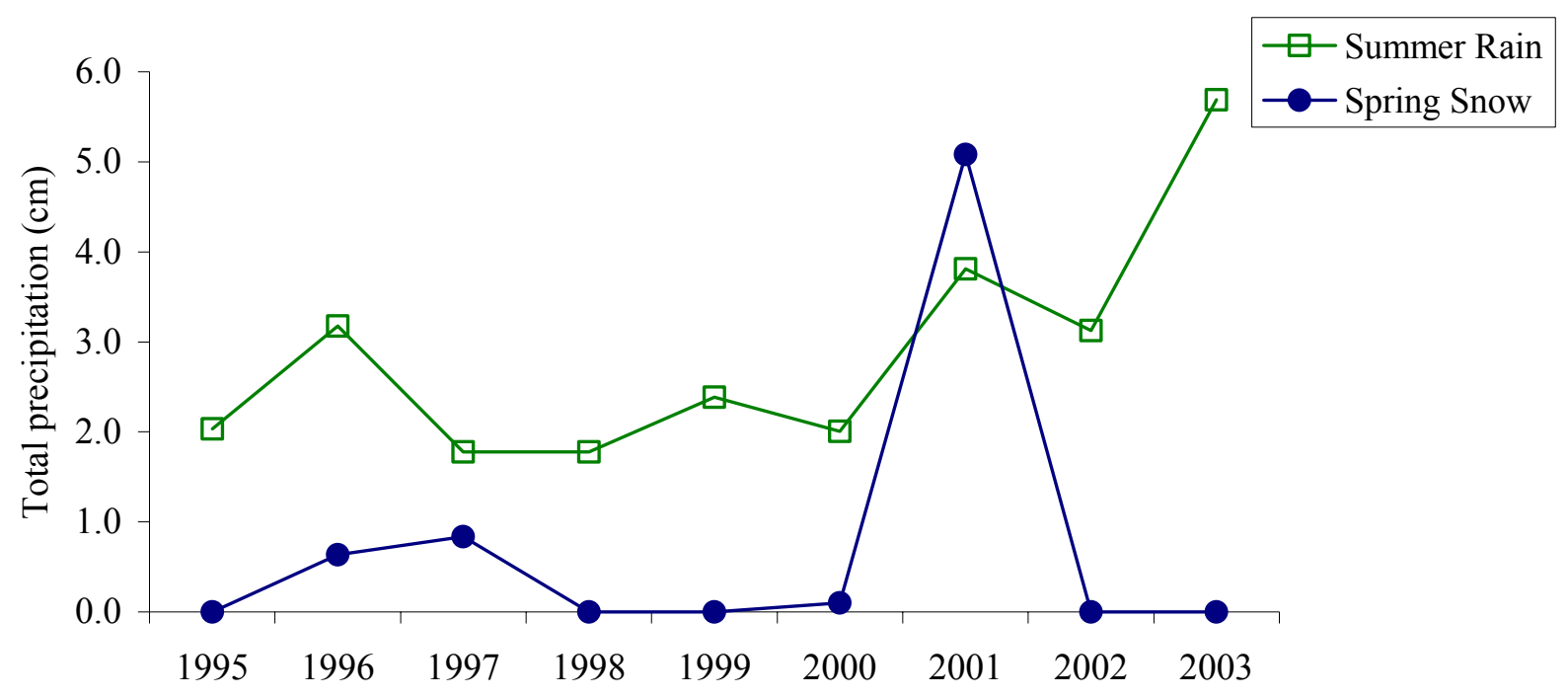

Figure 12 . Seasonal yearly totals of summer rainfall $(\mathrm{cm})$ and spring snowfall $(\mathrm{cm})$ from the Coopers Rock Weather Station located in the West Virginia University Research Forest, West Virginia, 1995-2003. 
Appendix A. List of common and scientific names for all species included in each mast category.

\begin{tabular}{|c|c|c|}
\hline Mast category & Common name & Scientific name \\
\hline Hard & $\begin{array}{l}\text { American Beech } \\
\text { American Chestnut } \\
\text { Black Oak } \\
\text { Black Walnut } \\
\text { Chestnut Oak } \\
\text { Eastern hemlock } \\
\text { Hickory } \\
\text { Mockernut Hickory } \\
\text { Oak } \\
\text { Pignut Hickory } \\
\text { Red Maple } \\
\text { Red Oak } \\
\text { Scarlet Oak } \\
\text { Shagbark Hickory } \\
\text { Sugar Maple } \\
\text { White Pine } \\
\text { White Oak }\end{array}$ & $\begin{array}{l}\text { Fagus grandifolia } \\
\text { Castanea dentata } \\
\text { Quercus velutina } \\
\text { Juglans nigra } \\
\text { Quercus prinus } \\
\text { Tsuga canadensis } \\
\text { Carya spp. } \\
\text { Carya tomentosa } \\
\text { Quercus spp. } \\
\text { Carya glabra } \\
\text { Acer rubrum } \\
\text { Quercus rubra } \\
\text { Quercus coccinea } \\
\text { Carya ovata } \\
\text { Acer saccharum } \\
\text { Pinus strobus } \\
\text { Quercus alba }\end{array}$ \\
\hline Soft & $\begin{array}{l}\text { Apple } \\
\text { Black Cherry } \\
\text { Black Gum } \\
\text { Blackberry } \\
\text { Crabapple } \\
\text { Downy Serviceberry } \\
\text { Flowering Dogwood } \\
\text { Greenbrier } \\
\text { Grape } \\
\text { Mountain Winterberry } \\
\text { Persimmon } \\
\text { Sassafras }\end{array}$ & $\begin{array}{l}\text { Malus sylvestris } \\
\text { Prunus serotina } \\
\text { Nyssa sylvatica } \\
\text { Rubus spp. } \\
\text { Malus coronaria } \\
\text { Amelanchier arborea } \\
\text { Cornus florida } \\
\text { Smilax rotundifolia } \\
\text { Vitis spp. } \\
\text { Ilex montana } \\
\text { Diospyros virginiana } \\
\text { Sassafras albidum }\end{array}$ \\
\hline Other & $\begin{array}{l}\text { American Basswood } \\
\text { Birch } \\
\text { Black Birch } \\
\text { Black Locust } \\
\text { Cottonwood } \\
\text { Cucumbertree } \\
\text { Hawthorne } \\
\text { Mountain Laural } \\
\text { Rosebay Rhododendron } \\
\text { Scrub Oak } \\
\text { Slippery Elm } \\
\text { Sourwood } \\
\text { Spicebush } \\
\text { Striped Maple } \\
\text { Witchhazel } \\
\text { White Ash } \\
\text { Yellow Birch } \\
\text { Yellow Poplar }\end{array}$ & $\begin{array}{l}\text { Tilia americana } \\
\text { Betula spp. } \\
\text { Betula lenta } \\
\text { Robinia pseudoacacia } \\
\text { Populus spp. } \\
\text { Magnolia acuminata } \\
\text { Crataegus spp. } \\
\text { Kalmia latifolia } \\
\text { Rhododendron maximum } \\
\text { Quercus ilicifolia } \\
\text { Ulmus rubra } \\
\text { Oxydendrum arboreum } \\
\text { Lindera benzoin } \\
\text { Acer pensylvanicum } \\
\text { Hamamelis virginiana } \\
\text { Fraxinus americana } \\
\text { Betula alleghaniensis } \\
\text { Liriodendron tulipifera }\end{array}$ \\
\hline
\end{tabular}




\title{
CHAPTER 3. GENETIC STRUCTURE AND PARENTAGE ANALYSIS OF AN ALLEGHENY WOODRAT POPULATION
}

\begin{abstract}
Microsatellite DNA was used to investigate levels of genetic variability among populations and subpopulations of the Allegheny woodrat, Neotoma magister, in northcentral West Virginia. Nine microsatellite markers were used to assess genetic variability within and between 2 naturally occurring populations separated by the Cheat River. Populations also were examined at the level of rock outcrops and groups of outcrops based on differentiation and topography. Levels of variability were quantified using allelic diversity, genotypic frequencies and heterozygosity. Overall mean heterozygosity was 59\% with a mean number of 6.7 alleles per locus. Evidence for population sub-structuring was examined using F statistics and isolation by distance. Low but significant levels of population differentiation were found at the level of the subpopulations and populations suggesting significant gene flow occurs between the study areas and that the Cheat River is not a complete barrier to dispersal. Parentage, kinship, and population assignment were examined using likelihood-based approaches. Likelihood analyses of juveniles suggests that woodrats average one to three young and that there is possibility for multiple male paternity. Results also suggest that on average, juvenile males disperse farther from their natal sites than juvenile females.
\end{abstract}

MOLECULAR ECOLOGY 00(0):000-000

\section{INTRODUCTION}

Within recent years, gene flow and genetic variation in natural populations have been examined in multiple species using microsatellite markers (Cunningham et al. 2002, Hinten et al. 2003, Kuehn et al. 2003). These polymorphic loci are DNA segments consisting of tandem repeats of short nucleotide motifs (Bruford and Wayne 1993, Queller et al. 1993). Larger numbers of repeats result in more alleles at each marker enabling researchers to distinguish

This chapter written in the style of the Molecular Ecology. 
between individuals and populations (Bruford and Wayne 1993, Queller and Goodnight 1993, Smouse and Chevillon 1998, Hansen et al. 2001). Microsatellites are also widely distributed throughout the eukaryotic genome so they can be applied to multiple species and disciplines (O’Connell et al. 1998, Adcock and Mulder 2002, Matocq 2004). Additionally, these markers are neutral so selection is negligible (Queller et al. 1993).

Examination of loci leads to a more complete understanding of multiple ecological parameters including dispersal, population differentiation, and social structure (Bruford and Wayne 1993, Queller et al. 1993, van de Zande et al. 2000). The variability among spatial distribution of alleles makes these co-dominant markers an invaluable tool for analysis of effective population size, inbreeding, and local gene flow (Bruford and Wayne 1993, Queller et al. 1993). The potential for discriminating among individuals allows analysis of parentage and kinship (Baker et al. 1999, Ohnishi et al. 2000). Assignment of parents depends on the ability to exclude all other candidates (Marshall et al. 1998). Exclusion probabilities increase with heterozygosity, which increases with the number of alleles. Therefore, the lower the heterozygosity, the more loci necessary for exclusion. The more alleles that are present only increases the ability to analyze maternal and paternal pairs because more differentiation among animals and potential breeding pairs is possible (Queller et al. 1993, Bossart and Prowell 1998).

These markers have already been developed for many species including the Allegheny woodrat (Neotoma magister) (Castleberry et al. 2002). This rodent is of interest because it is thought to exist naturally in metapopulations due to its specificity to disjunct rocky outcrops and talus slopes. Historically, it has been found throughout the Appalachian mountain range extending into Connecticut and New York. It has become a topic of study in recent decades due to a population decline throughout its range. Although there have been multiple ecological 
factors suggested for its reduced status, genetic variability has only recently been examined (Hayes and Harrison 1992, Edwards and Bradley 2001, Castleberry et al. 2002). These markers have been applied to Allegheny woodrat populations to determine species status and phylogenetic relationships (Hayes and Harrison 1992, Ray et al. 2002) as well as geographic population differentiation (Castleberry et al. 2002).

The current population of interest is located in northcentral West Virginia and was a component of a previous geographic population differentiation study (Castleberry et al. 2002). However, differentiation at a localized level has not been studied and more importantly, the affects of natural population structure have not been analyzed. The objectives of this research were to determine the genetic fitness of localized populations and subpopulations to gain a better understanding of the population dynamics based on genetic differentiation. Additional components of the research were to assess the parentage of individual woodrats to determine possible mating patterns and to aid in future juvenile dispersal studies.

\section{STUDY AREA}

Samples were collected at Coopers Rock State Forest (CR) and Snake Hill Wildlife Management Area (SH), located in Monongalia and Preston Counties, West Virginia (Refer to Ch.1, Fig. 1). Study areas are separated by the Cheat River, which flows in a northwesterly direction, forming a $400 \mathrm{~m}$ deep gorge in between the two areas. The northern sides of CR is bordered by I-68, which runs in an east-west direction. Forests are primarily used for recreation although SH is subjected to periodic timbering. Both study areas are part of the Chestnut/Laurel Ridges of the western edge of the Appalachian Mountains and woodrat colonies existing within this region are considered part of the Chestnut/Laurel Ridge metapopulation. 
Previous analyses of woodrat colonies at $\mathrm{CR}$ and $\mathrm{SH}$ delineated subpopulations according to neighbor-joining cluster analysis and geographic proximity of colonies (Fig. 1, Castleberry et al. 2002). This resulted in four subpopulations within the overall study area (3 at CR and 1 at $\mathrm{SH})$. Given the sample size and the objectives of this study, 19 individual colonies or rock outcrops were initially identified and analyzed (Fig. 2). Subpopulations were ultimately defined based on the linear nature of rock outcrops and the differentiation among assemblages (Fig. 3).

\section{MATERIALS AND METHODS}

Sample Collection

During a long-term mark/recapture study, 197 tissue samples were collected via ear biopsy from individual Allegheny woodrats during 1999, 2001, and 2002. A total of 153 animals were sampled at CR and 44 at SH. All animals were captured in Tomahawk live traps (Tomahawk Live Trap Co., Tomahawk, Wisconsin) and individually identified using a single aluminum ear tag and/or a unique passive integrated transponder (PIT) tag (Electronic ID, Inc. Cleburne, Texas) inserted beneath the skin. Gender and reproductive condition were recorded. Animals capable of reproducing based on morphology and age (estimated by time of capture and weight at time of capture) were classified as adults. All other animals were presumed to be juveniles born during the year of capture and not yet capable of breeding. Tissue samples were placed in $95 \%$ ethanol and kept in a $4{ }^{\circ} \mathrm{C}$ refrigerator until extraction.

DNA Extraction and Amplification

Genomic DNA was isolated using Puregene ${ }^{\circledR}$ DNA extraction kit D-7000A (Gentra Systems, Minneapolis, MN). Previously, 13 microsatellite loci were developed for the Allegheny woodrat (Castleberry et al. 2000). To determine parentage, nine loci were chosen based on 
polymorphism and ability to amplify and score alleles consistently (Table 1). Nma02 and Nma06 were not used in analysis due to difficulty and inconsistency in amplification. Nma03 was not used because it was previously discovered to be monomorphic (Castleberry et al. 2002). Nma09 was not used due to lack of primers. Thermal cycling of microsatellite loci was performed on a MJ DNA Engine (PTC 200, MJ Research) with a heated lid following modified methods of Castleberry et al. (2000). Reactions were carried out in $10 \mu \mathrm{l}$ volumes using approximately 100200 ng DNA, 1X PCR buffer, $0.20 \mathrm{mM}$ dNTP, 5 pmol of each primer, and 0.06 units of Taq polymerase (New England BioLabs, Beverly, MA). Forward primers were modified with 6FAM, TET, or HEX fluorescent labels (Perkin-Elmer Applied Biosystems, Inc., Foster City, CA). All PCR profiles were the same with an initial denaturating step for 3 minutes at $94{ }^{\circ} \mathrm{C}$ followed by 35 cycles of $94{ }^{\circ} \mathrm{C}$ denaturing for $30 \mathrm{sec}, 56^{\circ} \mathrm{C}$ annealing for $30 \mathrm{sec}$, and $72{ }^{\circ} \mathrm{C}$ extension for $1 \mathrm{~min}$. Samples were then held at $72{ }^{\circ} \mathrm{C}$ for $10 \mathrm{~min}$ for final extension and stored at $4{ }^{\circ} \mathrm{C}$.

Capillary electrophoresis and sample scoring

For analysis, $1 \mu$ of PCR product was diluted (1:75 or 1:100) with deionized water. One $\mu 1$ of the PCR dilution was then added to $12 \mu 1$ (1:100) of deionized formamide and internal size standard GENESCAN-GS400HD (Applied Biosystems, Foster City, California). The resulting $13 \mu 1$ mixture of product, formamide, and size standard was denatured at $95{ }^{\circ} \mathrm{C}$ for 5 minutes and placed on ice for 5 minutes. The samples were then subjected to capillary electrophoresis on an Applied Biosystem PRISM 310 Genetic Analyzer and the resulting fluorescently labeled DNA fragments were scored using GENESCAN and GENOTYPER software packages (Applied Biosystems version 2.0). Allelic and genotypic designations were assigned for individual 
woodrats. Due to the ambiguities that can arise with dinucleotide repeats, all allelic designations were verified for consistency in scoring (Queller et al. 1993).

\section{STATISTICAL ANALYSES}

Genetic polymorphism

Genetic diversity among the two study areas and among the subpopulations was measured at each specific locus as the number of alleles per locus (A) and expected and observed heterozygosity (He and Ho, respectively) along with estimates of allelic and genotypic frequency distributions. Tests for deviation from Hardy-Weinberg equilibrium (HWE) were performed using the Markov chain randomization test (Guo and Thompson 1992, Raymond and Rousset $1995)$ to estimate 2 -tailed $P$-values for each locus in the overall population and among the subpopulations. Significant heterozygote deficiency or excess per locus and subpopulation (Raymond and Rousset 1995) also were calculated. To examine physical linkage among loci, linkage disequilibrium was estimated for each genotype. All of the above procedures were calculated using GENEPOP software package, v 3.1 c (Raymond and Rousset 1995). Sequential Bonferroni adjustments were applied to all critical values to correct for the effect of multiple tests of the same hypothesis (Rice 1989).

Population structure

Genetic differentiation within and among subpopulations was quantified using two different fixation indices $\left(\mathrm{F}_{\mathrm{st}}\right.$ and $\left.\mathrm{R}_{\mathrm{st}} ; P<0.05\right)$ (Balloux and Lugon-Moulin 2002) due to the uncertainty of microsatellite mutation processes (Balloux and Goudet 2002, Neigel 2002). Estimation of $\mathrm{F}_{\text {st }}$ was calculated using FSTAT (Goudet 1995) and $\mathrm{R}_{\text {st }}$ using RSTCALC (Goodman 1997). Both programs use permutation procedures to test for significant differences in 
calculated values but $\mathrm{F}_{\mathrm{st}}$ estimates are calculated assuming an infinite alleles model (IAM;

Kimura and Crow 1964) to generate theta ( $\theta$; Weir and Cockerham 1984) while $\mathrm{R}_{\text {st }}$ calculations assume a stepwise mutation model (SMM; Kimura and Otha 1978) to generate rho ( $\rho$; Slatkin 1995). To account for multiple tests of the same hypothesis, critical values were adjusted using Bonferroni adjustments (Rice 1989). Estimates of gene flow were represented as the number of effective migrants per generation $\left(\mathrm{N}_{\mathrm{e}} \mathrm{m}\right)$ calculated using Wright's fixation index (Wright 1943) where $\mathrm{F}_{\mathrm{st}}=1 /\left(4 \mathrm{~N}_{\mathrm{e}} \mathrm{m}+1\right)$.

Isolation by distance between individuals was calculated using the subprogram ISOLDE in GENEPOP. It computes a regression of $\mathrm{F}_{\mathrm{st}} /\left(1-\mathrm{F}_{\mathrm{st}}\right)$ (Rousset 1997) estimates to straight line spatial distances. Spatial distances were measured in ArcView 3.2a ${ }^{\circledR}$ (Environmental Systems Research Institute, Inc., Redlands, California) as the shortest distance between each subpopulation and between the specific location of captures. Correlations between genetic and spatial distance matrices were assessed for significance using a Mantel randomization test with 1000 permutations per comparison performed by the isolation by distance option in GENEPOP (Mantel 1967).

Population assignment

Assignment tests were used to determine the probability that each individual's genotype belonged to the population from which it was sampled (Hansen et al. 2001). The program GENECLASS 1.0.02 (Cornuet et al. 1999) was used to assign individuals to the population in which the likelihood of their genotype is the highest. This program uses a Bayesian approach to estimate the likelihood that an individual's multilocus genotype occurs in the given population. A $\chi^{2}$ test determined the significance of the correct assignments by comparing the observed numbers of correct classifications to the numbers correctly classified by chance. 
Parentage and kinship

Parental relationships were analyzed using software packages PAPA (Duchesne et al. 2002) and CERVUS (Marshall et al. 1998). PAPA assigns parentage based on the breeding likelihood of a parental pair producing the given offspring's genotype. This method allows for some error from genotype misreading and mutation (Duchesne et al. 2002). CERVUS uses the likelihood-based approach for paternity assignment and considers the number of candidate males, the proportion of males sampled and possible errors in the genetic data (Marshall et al. 1998). For parental pair assignments, both software packages were used jointly. Those juveniles that were not assigned a pair based on either program were linked to the male or female with highest likelihood from the CERVUS output.

Because woodrats can potentially breed for more than one year, I assumed that multiple generations bred during a given year. Because data were collected during 1999 and then again from 2001-2002, there was a possibility of overlap between juveniles and breeding adults. Therefore, parentage was estimated using different years of data and different groups of animals based on their current breeding condition. Adults and juveniles captured in 1999 were compared. Juveniles from 2001 were compared with all 1999 captures, 2001 adults, and 2002 adults that were recaptures from earlier years. Parentage of 2002 juveniles was estimated with all captures. Parentage analyses were run separately for the two different study sites; due to the lack of juvenile captures at SH in 1999 and 2001, parentage was estimated only for 2002 juvenile captures.

Relatedness levels at the individual study area and the overall population were analyzed using the software program KINSHIP (Goodnight and Queller 1999), which calculates individual pairwise relatedness ( $r$ ) based on equations developed by Queller and Goodnight (1989). 
Relatedness among full siblings was calculated using specified $r$ values $\left(r_{\mathrm{m}}=0.5, r_{\mathrm{p}}=0.5\right)$, population allele frequencies, and individual genotypes. Maternal $\left(r_{\mathrm{m}}=1.0, r_{\mathrm{p}}=0.0\right)$ and paternal $\left(r_{\mathrm{m}}=0.0, r_{\mathrm{p}}=1.0\right)$ likelihoods were also analyzed. Potential incidences of multiple paternity were analyzed further using $r_{\mathrm{m}}=0.5, r_{\mathrm{p}}=0.0$.

\section{RESULTS}

Microsatellite variation

Multilocus genotypes were generated for 197 woodrats from nine microsatellite loci. Genetic characteristics of all microsatellite loci are summarized in Table 1. A total of 60 alleles were observed across nine loci ranging from two at Nma05 and Nma12 to 15 at Nmal0. The average number of alleles per locus was 5.9 at $\mathrm{CR}$ and 5.8 at $\mathrm{SH}$ and 6.7 when both areas were considered together. Mean heterozygosity was 0.59 at $\mathrm{CR}$ and 0.60 at $\mathrm{SH}$ with an overall mean of 0.59. Allele frequencies for all loci are described in Table 2.

Significant deviations from Hardy-Weinberg equilibrium (HWE; $P<0.05$ ) at CR were observed at $\mathrm{Nma01}(P=0.005), \operatorname{Nma08}(P<0.0001)$, and Nmal0 $(P=0.006)$. Departure from HWE at SH was detected at $\operatorname{Nma01}(P=0.022)$ and $\operatorname{Nmal4}(P=0.034)$. After applying sequential Bonferroni adjustments for multiple comparisons $(\alpha=0.002)$, only Nma08 at CR was determined to be significantly different from HWE. Additional multilocus tests for heterozygote deficiencies indicated that $\operatorname{Nma08}(P=0.006)$ was significantly deficient along with $N m a 10(P=$ $0.007)$ at $\mathrm{CR}$ and $\mathrm{Nma12}(P=0.040)$ at $\mathrm{SH}$. When subpopulations were tested separately, all were determined to be in HWE and no groups were determined to be deficient. Because heterozygote deficiency trends across loci were not seen and no subpopulations were found to deviate significantly from HWE, all loci were included in analyses. 
Of the 197 woodrats screened, all individuals demonstrated unique multilocus genotypes. Assuming that the genotyping was not biased due to human error, there is a low possibility of identical twins. The frequency of unique alleles within the two study areas and the individual subpopulations was low (0.04) suggesting that there is a low occurrence of immigration from outside populations or that there is little differentiation among the subpopulations. Genotypic disequilibrium was significant for most locus pairs overall, as 15 of 36 locus comparisons (41.67\%) were significant after Bonferroni correction was applied $(\alpha=0.001)$. Four locus comparisons were significant at $\mathrm{SH}$ while 14 were significant at $\mathrm{CR}$ indicating that physical linkage is highly probable.

Population differentiation

The standardized allele frequency $\left(\mathrm{F}_{\mathrm{st}}\right)$ value between the two study areas was significant $(\theta=0.120 ; P<0.05)$. Pairwise comparisons using $\mathrm{R}_{\mathrm{st}}$ resulted in similar results as those generated by $\theta(\rho=0.166 ; P<0.05)$. Significant values of $\mathrm{F}_{\mathrm{st}}$ and $\mathrm{R}_{\mathrm{st}}$ were seen among certain individual outcrops suggesting connectivity between specific outcrops. Given the linear nature of the rocks and the location of hindrances such as roads and ridges, the rocks were grouped accordingly and tested for differentiation. All grouped subpopulations (Fig. 2) demonstrated low but significant differentiation using both indices (Table 3) with $F_{\text {st }}$ ranging from 0.081 to 0.216 and $R_{\text {st }}$ values between 0.012 and 0.291 . Given the moderate sample size and number of loci tested, $\theta$-based estimates of gene flow $\left(\mathrm{N}_{\mathrm{e}} \mathrm{m}\right)$ were analyzed (Gaggiotti et al. 1999). Gene flow estimates were low ranging from 0.16 to 3.09 effective migrants per population (Table 4 ). The highest estimated gene flow and lowest differentiation occurred for subpopulations CR2 and SH1, groups separated by the Cheat River. 
Structure among the subpopulations due to spatial distances was significant (Table 5, Fig. 4). Genetic and spatial distances also were significantly related for individual outcrops (Table 6 , Fig. 5) even though all outcrops were not significantly differentiated. Individual assignment tests showed that classification was robust with $97.9 \%$ of the assignments correct between the two study areas and $82.6 \%$ at the subpopulation level (Table 7). Assignment at the study area and subpopulation level ranged from $75 \%$ to $100 \%$. At the overall population level, $100 \%$ of the assignments were higher than expected by chance alone indicating that migration from other populations is unlikely.

Parentage and kinship

In 1999, 23 juveniles and 36 adults were captured. Likelihood analyses of these juveniles identified maternity for nine and paternity for seven. The remaining seven juveniles were identified to a parental pair. There were 15 candidate males of which 10 were identified to an offspring. Seven of these 10 were linked to a single pup, two were linked to two, and the remaining adult male was linked to the remaining three offspring. Relatedness values among potential siblings indicated a significant full sibling relationship between all siblings. Of the 21 candidate females, 11 were assigned offspring. The majority were only linked to one offspring but two were linked to two, and the remaining individual was linked to 3 .

There were 13 juveniles from 2001 and 77 candidate parents. Three juveniles were assigned a parental pair. Six of the remaining 10 were linked to a male while four were linked to a female. Of the 39 candidate males, eight were linked with offspring. One male was linked to two juveniles, who were full siblings; the remaining seven were linked to a single offspring. Of the 38 candidate females, four were estimated maternity. Two had one pup, one had two pups, and one had three. 
In 2002, 35 juvenile captures were compared with 112 candidate parents. Parental pairs were only assigned to 6 of the juveniles but all remaining juveniles were linked to either a maternal or paternal woodrat. Sixteen males were linked to a single offspring, while two remaining males were estimated with two and four offspring. There were 13 females linked to offspring: 10 to a single young, two to two, and one to three. All offspring with the same parents were significantly related as full siblings.

Significant half sibling relationships were observed among juveniles with the same maternal but not paternal parent within the same year. Woodrats can have multiple litters in one breeding season. Therefore, it is impossible to tell if half sibling relationships are from the same litter, an indication of multiple paternity per litter, or if the relationship is between different litters of the same year.

Distances between likely maternal-offspring and paternal-offspring pairs were calculated based on time of capture. These distances were determined for all male and female juvenile captures and in subsequent years for all juveniles recaptured as adults. Average distance from maternal woodrats was lower for juvenile females than juvenile males at both the juvenile and adult stage (Fig. 6). However, differences seen were not significant. The range of distances between significant maternal-offspring pairs indicates that both sexes are potential dispersers (Fig. 7). The same pattern was observed between paternal-offspring pairs in which juvenile females were generally captured closer to a paternal woodrat than juvenile males (Fig. 8). This occurred at the juvenile and adult stages although no relationships were significant. Average distances were larger than those calculated for maternal-offspring pairs but the range of distances was similar for both males and females (Fig. 9). 


\section{DISCUSSION}

Local populations demonstrated low but significant genetic variation and should be monitored closely as this may be indicative of further isolation of populations (van de Zande et al. 2000). The average heterozygosity value of 0.59 and average alleles per locus of 5.9 is intermediate to that of other endangered and nonendangered rodent species (van de Zande et al. 2000, Hinten 2003, Tefler et al. 2003, Winters and Waser 2003) but lower than other woodrat species. Analysis of the dusky-footed woodrat (Neotoma fuscipes) found allelic diversity between six microsatellites ranging from five to 12 alleles with an observed average heterozygosity of 0.82 (Matocq 2001, Matocq 2004). Previous studies on the Allegheny woodrat throughout its range found an average expected heterozygosity of 0.62 and 10.4 alleles per locus ranging from five to nineteen (Castleberry et al. 2002). Similar polymorphism was found in the original study of the CR and SH populations but there are reductions at specific loci (Table 1). This may be attributed to the smaller spatial scale analyzed or a loss in genetic variation. This is also true for the observed range in base pairs attributed to the fact that certain alleles were absent in our study population. Two loci, Nmalo and Nmall, were found to have more alleles than the original study. This may be due to mutation of the dinucleotide repeat sequences (Callen et al. 1993) or the larger range of base pairs analyzed in the 2001 and 2002 data. Nma11 shows an additional allele at 132 in eight individuals. It is possible that this allele is unique to the CR population but this theory cannot be tested without analyzing additional geographic populations with a larger base pair range.

When the two study areas were tested separately, all loci, except Nma08, met the assumptions of HWE. Selection acting on linked loci is often a cause of deviation from HWE (Rousset and Raymond 1995) and multiple alleles were significantly linked in both populations. 
Linkage was also prevalent in previous studies of the $\mathrm{CR}$ and SH populations (Castleberry et al. 2002) and could indicate a significant limitation in migration between the two populations (Ohta 1982). Heterozygote deficiencies were also detected in both populations indicating possible inbreeding within the populations (Bruford and Wayne 1993). However, these trends were not seen at the subpopulation level indicating that deviation could be a result of pooling data (Frankham et al. 2002). The lack of loci specific heterozygote deficiencies across subpopulations suggests that null alleles occur at low frequencies if they occur at all. Null alleles are alleles that fail to become visualized resulting in homoplasy. Null alleles, along with population subdivision, have been recognized as a major factor in the depression of observed heterozygosity when compared with expected (Callen et al. 1993). The low occurrence of null alleles suggests that there were few mutations in the primer sites that could potentially result in scoring a true heterozygote as a homozygote due to amplification of only one of the two alleles present (Bruford and Wayne 1993). Therefore, all alleles were used for estimations of parentage and kinship.

Estimates of genetic structure and gene flow should be analyzed cautiously as there are multiple sources of error such as choice of estimation model, assumption violations, and inadequate or improper sampling of range (Bossart and Prowell 1998, Gaggiotti et al. 1999, Neigel 2002). Because the population is weakly structured and the sample size was moderate, $F_{\mathrm{st}}$ values were used for comparison (Gaggiotti et al. 1999, Balloux and Goudet 2002) along with isolation by distance (Slatkin 1993, Goldstein et al. 1995). Variance in allele frequencies among populations $\left(\mathrm{F}_{\mathrm{st}}\right)$ ranged from 0.061 to 0.216 with lower levels indicating higher migration (Bossart and Prowell 1998, Frankham et al. 2002). Interestingly enough, the lowest value occurred between subpopulations separated by the Cheat River suggesting that the river does not 
impede migration between populations. When compared to previous studies of the area, there is an increase in migrants across the river leading to a reduction in differentiation between the two sides suggesting that the larger sample size included additional animals or their descendents that may have traveled across. Although it was always considered possible that woodrats are able to travel during periods of low flow, there have never been field observations to support this claim. The lowest migration was between subpopulations separated by the greatest distance which would be expected.

Structuring of the population, although weak, is significant and is related directly to distance and not to roads or other barriers. Isolation by distance randomizations showed similar results and indicate that there is low but significant structure of the subpopulations as well as individual outcrops suggesting that lack of movement among outcrops does structure the population but does not limit gene flow. Plots of genetic isolation by spatial distance demonstrate this slight structuring but overall the populations, at the distances tested, do not show any significant structuring further supporting the potential for a panmictic population. Assignment tests indicate that both populations were correctly assigned and that the majority of the subpopulations were assigned correctly. This supports the implication for structured populations but the ambiguity in assignments suggests that woodrats are still moving between and among outcrops. The reduction in assignment tests that is seen within the SH population is most likely a reflection of the reduced sample size.

Based on the parentage estimates, litters may range from one to four offspring. Of the potential parents, the majority of them were not linked to any offspring. Given the low juvenile captures, it is likely that juveniles are dispersing and were not tested (Neff 2000). Recapture data and location to maternal and paternal woodrats suggests that like other mammalian species, male 
woodrats average greater dispersal distances (Greenwood 1980, Wolff 1994). There is evidence for large-scale female movement as well but it is difficult to assess whether movements of both sexes are due to juvenile dispersal, maternal or paternal movement, or both. The distances between related animals were much more pronounced when juveniles were recaptured as adults suggesting that woodrats of both sex do exhibit some level of philopatry during their juvenile year. Zuck (unpub. data) saw an increase in juvenile dispersal the following spring possibly correlated to periods of higher food availability and less energy expenditure. Litters are significantly related at the full sibling level but there was some indication of half sibling relationships. Because littermates were unknown, evidence for half sibling relationships suggests that different males sired littermates or that females mate with multiple males throughout the breeding season. There are many other studies that demonstrate multiple paternity in rodent species including shrews (Tegelstrom et al. 1991) and mice (Baker et al. 1999, Ohnishi 2000). Male-biased dispersal is also more prevalent in polygynous species (Greenwood 1980). Further evidence of movement among individuals of known relatedness is necessary to determine juvenile dispersal rates and distances.

A reduction in genetic variation does not necessarily mean immediate extinction (Leberg 1990). There are instances when habitat fragmentation and the subdivision of populations are genetically advantageous because it may lead to greater genomic division (Bossart and Prowell 1998). Subdivided populations lose variability from the subpopulation at a greater rate but retain variation across the subpopulation better than random or panmictic populations (Lacy 1987). It is possible that this reduction in variation and subsequent differentiation is advantageous for populations. Therefore, genetic impacts on populations should be used as a management flag to attempt to preserve variation for short-term influence on population viability and evolutionary 
flexibility (Leberg 1990). Demographic factors such as social structure, variation in life history caused by fluctuation in the environment, dispersal in spatially heterogeneous environments, and local extinction and colonization all affect population dynamics and cannot be overlooked in population management (Lande 1988). Metapopulations are further influenced by regular extinctions and recolonizations by individuals from multiple source colonies and should be monitored more intensively since there are natural fluctuations and disturbances to gene flow (Roach et al. 2001). The impact of fragmentation on genetic variability is highly dependent on the species in question as is evident by other studies of diversity across barriers in rodent populations (e.g. Gerlach and Musolf 2000, Mossman and Waser 2001).

\section{CONCLUSIONS AND CONSERVATION IMPLICATIONS}

Originally the two study areas were thought to be separate populations. However, analysis of gene flow indicates while dispersal across the river is low, it is not improbable. Changes made to the landscape in one area could affect dispersal to the other area and therefore, management decisions must take this into account. Migration from populations outside of $\mathrm{CR}$ and SH is unlikely given the surrounding landscape and assignment probabilities of all animals tested. This does not mean that dispersal outside of the areas is unlikely. However, the surrounding areas are unsuitable woodrat habitats due to heavily traversed roadways and agricultural use of adjacent lands. There does seem to be adequate available habitat within the areas but it is not always connected. CR4 was the furthest population and there was evidence for dispersal to other populations through field and genetic analysis. As with all dispersal, greater distances mean greater risks and this would be enhanced with barriers such as the river and public roadways or even open forest. 
Further population structuring is seen at the individual outcrops level. Outcrops were originally separated in the field based on breaks of $>50 \mathrm{~m}$ in the rock line. However, there is not significant differentiation at this level among all outcrops. When outcrops are grouped according to the linear nature of the rock and the topography of the land, there is differentiation among the subpopulations. There is still movement between the subpopulations with some having a higher gene flow than others. This is most likely a result of higher numbers of samples collected among those connected outcrops as well as more movement between the closer subpopulations.

Relationships between genetic relatedness and spatial distance indicate that there is some significance between the two but that the population is relatively panmictic. The specificity for rock outcrops structures the population but is not isolating the population genetically. There does not seem to be a detrimental influence on female and male dispersal and reproduction. However, changes in the demographic distribution could severely alter the fecundity and negatively impact the population. The findings of genetic diversity suggest that there is adequate variation but future analysis of the population is critical to determine if the variation is decreasing at the localized level. Inbreeding does not seem to be a significant impact to the population as long as the population continues to reproduce and disperse at the current rate.

\section{LITERATURE CITED}

Adcock GJ, Mulder RA (2002) Polymorphic microsatellite loci for paternity analysis in the Madagascar paradise flycatcher (Terpsiphone mutata: Aves). Molecular Ecology Notes, 2, 287-289.

Baker RJ, Makova KD, Chesser RK (1999) Microsatellites indicate a high frequency of multiple paternity in Apodemus (Rodentia). Molecular Ecology, 8, 107-111. 
Balloux F, Lugon-Moulin N (2002) The estimation of population differentiation with microsatellite markers. Molecular Ecology, 11, 155-165.

Balloux F, Goudet J (2002) Statistical properties of population differentiation estimators under stepwise mutation in a finite island model. Molecular Ecology, 11, 771-783.

Bossart JL, Pashley Prowell D (1998) Genetic estimates of population structure and gene flow: limitations, lessons and new directions. Trends in Ecology and Evolution, 13, 202-206.

Bruford MW, Wayne RK (1993) Microsatellites and their application to population genetic studies. Current Opinions in Genetics and Development, 3, 939-943.

Callen DF, Thompson AD, Shen Y, Phillips HA, Richards RI, Mulley JC, Sutherland GR (1993) Incidence and origin of "Null" alleles in the (AC)n microsatellite markers. American Journal of Human Genetics, 52, 922-927.

Castleberry SB, King TL, Wood PB, Ford WM (2000) Microsatellite DNA markers for the study of Allegheny woodrat (Neotoma magister) populations and cross-species amplification in the genus Neotoma. Molecular Ecology, 9, 817-829. (2002) Microsatellite DNA analysis of population structure in Allegheny woodrats (Neotoma magister). Journal of Mammalogy, 83, 1058-1070.

Cornuet JM, Piry S, Luikart G, Estoup A, Solignac M (1999) New methods employing multilocus genotypes to select or exclude populations as origins of individuals. Genetics, 153, 1989-2000.

Cunningham JE, Baard HW, Harley EH, O'Ryan C (2002) Investigation of genetic diversity in fragmented geometric tortoise (Psammabates geometricus) populations. Conservation Genetics, 3, 215-223. 
Duchesne P, Godbout MH, Bernatchez L (2002) PAPA (Packages for the Analysis of Parental Allocation): A computer program for simulated and real parental allocation. Molecular Ecology Notes, 2, 191-194.

Edwards CW, Bradley RD (2001) Molecular phylogenetics of the Neotoma floridana species group. Journal of Mammalogy, 82, 791-798.

Frankham R, Ballou JD, Briscoe DA (2002) Introduction to Conservation Genetics. Cambridge University Press, Cambridge, UK.

Gaggiotti OE, Lange O, Rassmann K, Gliddon C (1999) A comparison of two indirect methods for estimating average levels of gene flow using microsatellite data. Molecular Ecology, 8, 1513-1520.

Gerlach G, Musolf K (2000) Fragmentation of landscape as a cause for genetic subdivision in bank voles. Conservation Biology, 14, 1066-1074.

Goodman SJ (1997) $\mathrm{R}_{\mathrm{st}}$ Calc: a collection of computer programs for performing likelihood tests of pedigree relationships using genetic markers. Molecular Ecology, 8, 1231-1234.

Goodnight KF, Queller DC (1999) Computer software for performing likelihood tests of pedigree relationship using genetic markers. Molecular Ecology, 6, 881-885.

Goudet J (1995) FSTAT, Version 1.2, a computer program to calculate F-statistics. Journal of Heredity, 86, 485-486.

Guo SW, Thompson EA (1992) Performing the exact test of Hardy-Weinberg proportion for multiple alleles. Biometrics, 48, 361-372.

Hansen MM, Kenchington E, Nielsen EE (2001) Assigning individual fish to populations using microsatellite DNA markers. Fish and Fisheries, 2, 93-112.

Hayes JP, Harrison RG (1992) Variation in mitochondrial DNA and the biogeographic history of woodrats (Neotoma). Systematic Biology, 41, 331-344. 
Hinten G, Harriss F, Rossetto M, Braverstock PR (2003) Genetic variation and island biogeography: Microsatellite and mitochondrial DNA variation in island populations of the Australian bust rat, Rattus fuscipes greyii. Conservation Genetics, 4, 759-778.

Kimura M, Crow JF (1964) The number of alleles that can be maintained in a finite population. Genetics, 49, 725-738.

, Otha T (1978) Stepwise mutation model and distribution of alleles in a finite population. Proceedings of the National Academy of Sciences of the USA, 75, 2868-2872.

Kuehn R, Schroeder W, Pirchner F, Rottmann O (2003) Genetic diversity, gene flow and drift in Bavarian red deer populations (Cervus elaphus). Conservation Genetics, 4, 157-166.

Lacy RC (1987) Loss of genetic diversity from managed populations: interacting effects of drift, mutation, immigration, selection, and population subdivision. Conservation Biology, 1, $143-158$.

Lande R (1988) Genetics and demography in biological conservation. Science, 241, 1455-1460.

Leberg PL (1990) Influence of genetic variability on population growth: implications for conservation. Journal of Fish Biology, 37, 193-195.

Marshall TC, Slate J, Kruuk LEB, Pemberton JM (1998) Statistical confidence for likelihoodbased paternity inference in natural populations. Molecular Ecology, 7, 639-655.

Matocq MD (2001) Characterization of microsatellite loci in the dusky-footed woodrat, Neotoma fuscipes. Molecular Ecology Notes, 1, 194-196.

(2004) Reproductive success and effective population size in woodrats (Neotoma macrotis). Molecular Ecology, 13, 1635-1642

Mossman CA, Waser PM (2001) Effects of habitat fragmentation on population genetic structure in the white-footed mouse (Peromyscus leucopus). Canadian Journal of Zoology, 79, 285-295. 
Neff BD, Repka J, Gross MR (2000) Parentage analysis with incomplete sampling of candidate parents and offspring. Molecular Ecology, 9, 515-528.

Neigel JE (2002) Is $\mathrm{F}_{\text {st }}$ obsolete? Conservation Genetics, 3, 167-173.

Ohnishi N, Saitoh T, Ishibashi Y (2000) Spatial genetic relationships in a population of the Japanese wood mouse Apodemus argenteus. Ecological Research, 15, 285-292.

Ohta T (1982) Linkage disequilibrium due to random genetic drift in finite subdivided populations. Proceedings of the National Academy of Sciences of the United States of America, 79, 1940-1944.

Queller DC, Straussman JE, Hughes CR (1993) Microsatellites and kinship. Trends in Ecology and Evolution, 8, 285-288.

Queller DC, Goodnight KF (1989) Estimating relatedness using genetic markers. Evolution, 43, $258-275$.

Ray DK, Freshwater DW, Webster WMD (2002) Multiplex PCR identification of Eastern and Allegheny woodrats in zones of contact. Journal of Wildlife Management, 66, 86-90.

Raymond M, Rousset F (1995) GENEPOP (version 1.2): population genetics software for exact tests ecumenicism. Journal of Heredity, 86, 248-249.

Rice WR (1989) Analyzing tables of statistical tests. Evolution, 43, 223-225.

Rousset F (1997) Genetic differentiation and estimation of gene flow from $F$-statistics under isolation by distance. Genetics, 145, 1219-1228. , Raymond M (1995) Testing heterozygote excess and deficiency. Genetics, 140, 14131419.

Slatkin M (1987) Gene flow and the geographic structure of natural populations. Science, 236, 787-7992. 
(1993) Isolation by distance in equilibrium and non-equilibrium populations. Evolution, 47, 264-279.

(1995) A measure of population subdivision based on microsatellite allele frequencies. Genetics, 139, 457-462.

Smouse PE, Chevillon C (1998) Analytical aspects of population-specific DNA fingerprinting for individuals. Journal of Heredity, 89, 143-150.

Tegelstrom J, Searle J, Brookfield J, Mercer S (1991) Multiple paternity in wild common shrews (Sorex araneus) is confirmed by DNA fingerprinting. Heredity, 66, 373-379.

Telfer S, Piertney SB, Dallas JF, Stewart WA, Marshall F, Gow JL, Lambin X (2003) Parentage assignment detects frequent and large-scale dispersal in water voles. Molecular Ecology, 12, 1939-1949.

van de Zande LR, van Apeldoorn C, Blijdenstein AF, deJong D, van Delden W, Bijlsma R (2000) Microsatellite analysis of population structure and genetic differentiation within and between populations of the root vole, Microtus oeconomus in the Netherlands. Molecular Ecology, 9, 1651-1656.

Weir B, Cockerham CC (1984) Estimating F-statistics for the analysis of population structure. Evolution, 38, 1358-1370.

Winters JB, Waser PM (2003) Gene dispersal and outbreeding in a philopatric mammal. Molecular Ecology, 12, 2251-2259.

Wolff JO (1994) More on juvenile dispersal in mammals. Oikos, 71, 349-352. 
Table 1. Published sequences, reported repeat motif, number of published and observed alleles (A), published and observed size in base pairs (bp), and annealing temperature (AT) of forward and reverse primers for microsatellite loci (Castleberry et al. 2002).

\begin{tabular}{|c|c|c|c|c|c|c|c|}
\hline Locus & $\begin{array}{l}\text { Published } \\
\text { size (bp) }\end{array}$ & $\begin{array}{l}\text { Observed } \\
\text { size (bp) }\end{array}$ & $\begin{array}{c}\text { Published } \\
A\end{array}$ & $\begin{array}{c}\text { Observed } \\
A\end{array}$ & Repeat Motif & AT & Primer Sequence $\left(5^{\prime} 3^{\prime}\right)$ \\
\hline Nma01 & $314-322$ & $313-323$ & 6 & 6 & $(\mathrm{CA})_{20}$ & 56 & $\begin{array}{l}\text { F: AGGTTGGAGAGAGATAAGAGTCC } \\
\text { R: GGAGGAGATAGAGAAGGGAA }\end{array}$ \\
\hline $\mathrm{NmaO4}$ & $145-163$ & $151-161$ & 7 & 7 & $(\mathrm{GT})_{22}(\mathrm{GTT})_{1}(\mathrm{GT})_{2}$ & 56 & $\begin{array}{l}\text { F: CCAGCTACAGGTATAGCTTCTTC } \\
\text { R: CAGTTCTTTGGTCTCCATACAC }\end{array}$ \\
\hline Nma05 & $227-232$ & $227-231$ & 4 & 2 & $(\mathrm{GA}) 2(\mathrm{CA}) 10(\mathrm{CCA}) 11$ & 56 & $\begin{array}{l}\text { F: TGAAGTCAAAACCCAATGAG } \\
\text { R: GCAAAATGTCCTCCAGTTTC }\end{array}$ \\
\hline Nma08 & $125-135$ & $120-132$ & 7 & 6 & $(\mathrm{CA})(\mathrm{GA})(\mathrm{CA})_{14}$ & 56 & $\begin{array}{l}\text { F: AAGACTCACAAGGTGGAAGG } \\
\text { R: ACTTTCTGTGCTTTGTATTGC }\end{array}$ \\
\hline Nmalo & $186-224$ & $194-228$ & 14 & 15 & $(\mathrm{CCT})_{2}(\mathrm{CT})_{21}(\mathrm{CA})_{25}$ & 56 & $\begin{array}{l}\text { F: CCATTGGTAGACAGTCATGG } \\
\text { R: ACCAGTCCTGGTATCAAAATC }\end{array}$ \\
\hline Nmall & $150-160$ & $132-162$ & 8 & 9 & $(\mathrm{GT})_{20}$ & 56 & $\begin{array}{l}\text { F: AGCCACAGTCACATTCTCTG } \\
\text { R: GCAGTTTTCAATTTGGTCAG }\end{array}$ \\
\hline Nmal2 & $115-127$ & $116-119$ & 3 & 2 & $\begin{array}{l}(\mathrm{CAA})_{2}(\mathrm{CAG})(\mathrm{CAA})_{6} \\
(\mathrm{CAG})(\mathrm{CAA})\end{array}$ & 56 & $\begin{array}{l}\text { F: ATGCCCTTAAATACCACAGG } \\
\text { R: GAAACTATTTACATGTTGATATACGC }\end{array}$ \\
\hline Nmal4 & $144-160$ & $143-153$ & 7 & 5 & $(\mathrm{GT})_{14}$ & 56 & $\begin{array}{l}\text { F: TGATGACTCTAGCTTTTGTCAAG } \\
\text { R: ATATTTCATTGGACAACCCTGTG }\end{array}$ \\
\hline Nmal5 & $120-136$ & $118-132$ & 10 & 8 & $(\mathrm{CA})_{19}$ & 56 & $\begin{array}{l}\text { F: TAGGTGAGTGAATGCTCTTGC } \\
\text { R: TCATTCAGCTGTAATCACTGG }\end{array}$ \\
\hline
\end{tabular}


Table 2. Summary of Allegheny woodrat microsatellite polymorphism for populations and subpopulations sampled in West Virginia from 1999-2002. Variables are number of individuals captured $(\mathrm{N})$, expected and observed heterozygosity (He and Ho, respectively), and total number of alleles $(A)$ per locus. See Figure 2 for subpopulation abbreviations and distributions.

\begin{tabular}{|c|c|c|c|c|c|c|c|c|c|}
\hline \multirow[b]{2}{*}{ Locus } & \multicolumn{5}{|c|}{ Coopers Rock State Forest } & \multicolumn{3}{|c|}{$\begin{array}{l}\text { Snake Hill Wildlife } \\
\text { Management Area }\end{array}$} & \multirow[b]{2}{*}{ Overall } \\
\hline & CR1 & CR2 & CR3 & CR4 & Total & SH1 & SH2 & Total & \\
\hline \multicolumn{10}{|l|}{$\overline{\mathrm{Nma} 01}$} \\
\hline $\mathrm{N}$ & 64 & 56 & 12 & 17 & 151 & 36 & 8 & 44 & 195 \\
\hline $\mathrm{He}$ & 0.66 & 0.79 & 0.74 & 0.64 & 0.73 & 0.30 & 0.81 & 0.46 & 0.72 \\
\hline Но & 0.67 & 0.71 & 0.92 & 0.71 & 0.72 & 0.28 & 1.00 & 0.41 & 0.65 \\
\hline$A$ & 6 & 6 & 5 & 3 & 6 & 4 & 5 & 6 & 6 \\
\hline \multicolumn{10}{|l|}{ Nma04 } \\
\hline $\mathrm{N}$ & 64 & 57 & 12 & 17 & 152 & 36 & 8 & 44 & 196 \\
\hline $\mathrm{He}$ & 0.68 & 0.79 & 0.72 & 0.62 & 0.77 & 0.73 & 0.70 & 0.74 & 0.79 \\
\hline Ho & 0.67 & 0.81 & 0.92 & 0.65 & 0.74 & 0.81 & 0.63 & 0.77 & 0.75 \\
\hline$A$ & 5 & 6 & 4 & 5 & 6 & 7 & 5 & 7 & 7 \\
\hline \multicolumn{10}{|l|}{ Nma05 } \\
\hline $\mathrm{N}$ & 63 & 57 & 12 & 17 & 151 & 36 & 7 & 43 & 194 \\
\hline $\mathrm{He}$ & 0.19 & 0.48 & $\mathrm{~N} / \mathrm{A}$ & N/A & 0.31 & 0.28 & 0.49 & 0.32 & 0.31 \\
\hline Но & 0.21 & 0.53 & $\mathrm{~N} / \mathrm{A}$ & N/A & 0.28 & 0.28 & 0.71 & 0.35 & 0.30 \\
\hline$A$ & 2 & 2 & 1 & 1 & 2 & 2 & 2 & 2 & 2 \\
\hline \multicolumn{10}{|l|}{ Nma08 } \\
\hline $\mathrm{N}$ & 64 & 58 & 12 & 17 & 153 & 36 & 8 & 44 & 197 \\
\hline $\mathrm{He}$ & 0.69 & 0.70 & 0.59 & 0.78 & 0.75 & 0.67 & 0.68 & 0.67 & 0.75 \\
\hline Ho & 0.63 & 0.66 & 0.83 & 0.71 & 0.67 & 0.67 & 0.75 & 0.68 & 0.67 \\
\hline$A$ & 5 & 5 & 3 & 6 & 6 & 5 & 5 & 6 & 6 \\
\hline \multicolumn{10}{|l|}{ Nma10 } \\
\hline $\mathrm{N}$ & 63 & 58 & 12 & 16 & 151 & 36 & 8 & 44 & 195 \\
\hline $\mathrm{He}$ & 0.82 & 0.77 & 0.81 & 0.87 & 0.85 & 0.77 & 0.82 & 0.80 & 0.87 \\
\hline Ho & 0.73 & 0.67 & 0.92 & 1.00 & 0.77 & 0.75 & 1.00 & 0.80 & 0.76 \\
\hline$A$ & 10 & 10 & 5 & 9 & 12 & 9 & 6 & 10 & 15 \\
\hline \multicolumn{10}{|l|}{ Nma11 } \\
\hline $\mathrm{N}$ & 64 & 58 & 11 & 17 & 152 & 35 & 7 & 42 & 194 \\
\hline $\mathrm{He}$ & 0.54 & 0.69 & 0.54 & 0.75 & 0.66 & 0.71 & 0.84 & 0.74 & 0.68 \\
\hline Ho & 0.50 & 0.67 & 0.73 & 0.82 & 0.63 & 0.74 & 0.71 & 0.74 & 0.65 \\
\hline$A$ & 5 & 6 & 3 & 6 & 7 & 6 & 6 & 7 & 9 \\
\hline \multicolumn{10}{|l|}{ Nma12 } \\
\hline $\mathrm{N}$ & 64 & 58 & 12 & 17 & 153 & 36 & 8 & 44 & 197 \\
\hline $\mathrm{He}$ & 0.03 & 0.32 & $\mathrm{~N} / \mathrm{A}$ & N/A & 0.15 & 0.51 & N/A & 0.49 & 0.27 \\
\hline Ho & 0.03 & 0.36 & $\mathrm{~N} / \mathrm{A}$ & N/A & 0.15 & 0.42 & N/A & 0.34 & 0.19 \\
\hline$A$ & 2 & 2 & 1 & 1 & 2 & 2 & 1 & 2 & 2 \\
\hline \multicolumn{10}{|l|}{ Nma14 } \\
\hline $\mathrm{N}$ & 64 & 57 & 12 & 16 & 151 & 35 & 8 & 43 & 194 \\
\hline $\mathrm{He}$ & 0.71 & 0.74 & 0.67 & 0.69 & 0.74 & 0.71 & 0.65 & 0.74 & 0.76 \\
\hline Ho & 0.78 & 0.72 & 0.83 & 0.81 & 0.76 & 0.63 & 0.63 & 0.63 & 0.73 \\
\hline$A$ & 5 & 5 & 3 & 4 & 5 & 5 & 4 & 5 & 5 \\
\hline \multicolumn{10}{|l|}{ Nma15 } \\
\hline $\mathrm{N}$ & 63 & 57 & 12 & 17 & 151 & 36 & 8 & 44 & 195 \\
\hline $\mathrm{He}$ & 0.42 & 0.74 & 0.60 & 0.45 & 0.60 & 0.59 & 0.75 & 0.69 & 0.70 \\
\hline Ho & 0.37 & 0.77 & 0.75 & 0.47 & 0.56 & 0.61 & 0.88 & 0.66 & 0.59 \\
\hline A & 5 & 7 & 3 & 4 & 7 & 7 & 5 & 7 & 8 \\
\hline
\end{tabular}


Table 3. Matrix of genetic variation among Allegheny woodrat subpopulations sampled from 2 study areas, 1999-2002 ( $\mathrm{F}_{\text {st }}$ values are below the diagonal and $\mathrm{R}_{\mathrm{st}}$ are above the diagonal). All values are significantly different from zero after Bonferroni correction $(P<0.003)$. See Figure 3 for subpopulation abbreviations and distributions.

\begin{tabular}{lcccccc}
\hline & CR1 & CR2 & CR3 & CR4 & SH1 & SH2 \\
\hline CR1 & - & 0.016 & 0.032 & 0.063 & 0.015 & 0.199 \\
CR2 & 0.081 & - & 0.012 & 0.115 & 0.079 & 0.278 \\
CR3 & 0.082 & 0.084 & - & 0.125 & 0.112 & 0.291 \\
CR4 & 0.087 & 0.115 & 0.141 & - & 0.035 & 0.119 \\
SH1 & 0.130 & 0.061 & 0.162 & 0.130 & - & 0.125 \\
SH2 & 0.207 & 0.145 & 0.203 & 0.216 & 0.154 & - \\
\hline
\end{tabular}

Table 4. Matrix of genetic variation $\left(\mathrm{F}_{\mathrm{st}}\right.$; below the diagonal) and gene flow estimates $\left(\mathrm{N}_{\mathrm{e}} \mathrm{m}\right.$; above the diagonal) for Allegheny woodrat subpopulations sampled from 2 study areas, 19992002. See Figure 3 for subpopulation abbreviations and distributions.

\begin{tabular}{lcccccc}
\hline & CR1 & CR2 & CR3 & CR4 & SH1 & SH2 \\
\hline CR1 & - & 2.075 & 2.053 & 1.890 & 0.922 & 0.207 \\
CR2 & 0.081 & - & 1.990 & 1.180 & 3.085 & 0.722 \\
CR3 & 0.082 & 0.084 & - & 0.778 & 0.544 & 0.230 \\
CR4 & 0.087 & 0.115 & 0.141 & - & 0.922 & 0.156 \\
SH1 & 0.130 & 0.061 & 0.162 & 0.130 & - & 0.622 \\
SH2 & 0.207 & 0.145 & 0.203 & 0.216 & 0.154 & - \\
\hline
\end{tabular}

Table 5. Isolation by distance matrix of $\mathrm{F}_{\mathrm{st}} /\left(1-\mathrm{F}_{\mathrm{st}}\right)$ values (below the diagonal) and approximate spatial distances $(\mathrm{m})$ (above the diagonal) between subpopulations. See Figure 3 for subpopulation abbreviations and distributions.

\begin{tabular}{lcclccc}
\hline & CR1 & CR2 & CR3 & CR4 & SH1 & SH2 \\
\hline CR1 & - & 307.57 & 301.67 & 1976.41 & 1828.78 & 1539.98 \\
CR2 & 0.089 & - & 1032.40 & 2671.84 & 1536.45 & 1572.81 \\
CR3 & 0.089 & 0.091 & - & 1074.80 & 2545.31 & 2030.13 \\
CR4 & 0.095 & 0.130 & 0.164 & - & 4218.68 & 4068.47 \\
SH1 & 0.150 & 0.065 & 0.193 & 0.150 & - & 522.94 \\
SH2 & 0.261 & 0.170 & 0.255 & 0.276 & 0.182 & - \\
\hline
\end{tabular}


Table 6. Isolation by distance matrix of $\mathrm{F}_{\mathrm{st}} /\left(1-\mathrm{F}_{\mathrm{st}}\right)$ values (below the diagonal) and approximate spatial distances (m) (above the diagonal) between individual outcrops. Numbers in blue represent comparison among CR outcrops, green are among SH outcrops, and red are between CR and SH outcrops. See Figure 2 for outcrop distributions.

\begin{tabular}{|c|c|c|c|c|c|c|c|c|c|c|c|c|c|c|c|c|c|c|c|}
\hline & \multicolumn{12}{|c|}{ Coopers Rock State Forest } & \multicolumn{7}{|c|}{ Snake Hill Wildlife Management Area } \\
\hline & 1 & 2 & 3 & 4 & 5 & 6 & 7 & 8 & 9 & 10 & 11 & 12 & 13 & 14 & 15 & 16 & 17 & 18 & 19 \\
\hline 1 & - & 33.5 & 1106.9 & 2680.2 & 2576.9 & 2377.6 & 2001.1 & 1989.2 & 2768.4 & 2740.3 & 3358.8 & 3533.3 & 4079.6 & 4172.7 & 4192.6 & 4144.3 & 4175.0 & 4207.0 & 4221.1 \\
\hline 2 & 0.02 & - & 1351.8 & 2933.4 & 2840.7 & 2638.3 & 2197.9 & 2133.7 & 2957.9 & 2678.2 & 3266.3 & 3443.5 & 4292.2 & 4395.7 & 4368.2 & 4272.0 & 4256.1 & 4287.2 & 4252.5 \\
\hline 3 & 0.21 & 0.12 & - & 295.0 & 307.6 & 325.8 & 510.3 & 797.9 & 1052.5 & 1082.3 & 2865.4 & 3033.0 & 2090.5 & 2171.6 & 2247.5 & 2541.4 & 3667.5 & 2779.6 & 2883.1 \\
\hline 4 & 0.21 & 0.12 & 0.17 & - & 36.1 & 1010.2 & 1063.9 & 1433.6 & 966.2 & 1361.7 & 3621.8 & 3710.0 & 1737.4 & 1884.8 & 2037.3 & 2589.1 & 2806.3 & 3003.1 & 3121.8 \\
\hline 5 & 0.13 & 0.07 & 0.12 & 0.13 & - & 39.1 & 840.8 & 1213.0 & 905.2 & 1253.5 & 3498.5 & 3486.8 & 1718.8 & 1986.8 & 1827.7 & 2500.5 & 2699.2 & 2902.1 & 3013.3 \\
\hline 6 & 0.12 & 0.05 & 0.10 & 0.01 & 0.03 & - & 53.6 & 637.0 & 268.9 & 377.6 & 2643.1 & 2730.5 & 1454.6 & 1524.6 & 1554.8 & 1779.3 & 1914.8 & 2081.7 & 2163.2 \\
\hline 7 & 0.21 & 0.14 & 0.16 & 0.29 & 0.11 & 0.13 & - & 70.3 & 286.4 & 348.9 & 2224.4 & 2350.3 & 1551.6 & 1678.0 & 1657.3 & 1778.8 & 1928.6 & 2078.9 & 2155.3 \\
\hline 8 & 0.19 & 0.16 & 0.17 & 0.36 & 0.11 & 0.21 & 0.06 & - & 693.5 & 337.4 & 1658.1 & 1790.1 & 2084.0 & 2184.9 & 2104.1 & 1770.4 & 1795.0 & 1824.2 & 1889.3 \\
\hline 9 & 0.26 & 0.15 & 0.11 & 0.12 & 0.11 & 0.05 & 0.19 & 0.26 & - & 52.4 & 2383.1 & 2486.6 & 1010.9 & 1104.8 & 1128.7 & 1427.6 & 1550.2 & 1686.1 & 1825.1 \\
\hline 10 & 0.17 & 0.11 & 0.12 & 0.07 & 0.08 & 0.01 & 0.11 & 0.23 & 0.05 & - & 544.0 & 677.2 & 1381.3 & 1475.6 & 1448.8 & 1276.7 & 1355.5 & 1365.4 & 1412.4 \\
\hline 11 & 0.24 & 0.19 & 0.20 & 0.31 & 0.10 & 0.06 & 0.12 & 0.18 & 0.10 & 0.04 & - & 91.2 & 3357.4 & 3378.6 & 3183.3 & 2177.0 & 1990.4 & 1582.1 & 1410.3 \\
\hline 12 & 0.14 & 0.10 & 0.12 & 0.09 & 0.04 & 0.03 & 0.13 & 0.21 & 0.06 & 0.03 & 0.05 & . & 3348.1 & 3406.6 & 3125.3 & 2172.1 & 1975.4 & 1779.5 & 1266.0 \\
\hline 13 & 0.22 & 0.18 & 0.32 & 0.29 & 0.19 & 0.09 & 0.35 & 0.38 & 0.17 & 0.10 & 0.19 & 0.15 & - & 63.6 & 148.1 & 1078.8 & 1475.1 & 1722.2 & 1904.5 \\
\hline 14 & 0.23 & 0.18 & 0.21 & 0.29 & 0.15 & 0.07 & 0.30 & 0.29 & 0.09 & 0.08 & 0.12 & 0.09 & 0.03 & - & 162.1 & 1124.7 & 1497.2 & 1755.3 & 1948.5 \\
\hline 15 & 0.07 & 0.07 & 0.21 & 0.13 & 0.11 & 0.02 & 0.25 & 0.27 & 0.15 & 0.04 & 0.15 & 0.01 & 0.04 & 0.10 & - & 765.7 & 1177.0 & 1433.9 & 1647.6 \\
\hline 16 & 0.22 & 0.14 & 0.23 & 0.22 & 0.20 & 0.07 & 0.18 & 0.28 & 0.17 & 0.05 & 0.08 & 0.10 & 0.15 & 0.14 & 0.04 & - & 52.4 & 296.3 & 492.7 \\
\hline 17 & 0.34 & 0.26 & 0.38 & 0.30 & 0.27 & 0.08 & 0.40 & 0.45 & 0.18 & 0.10 & 0.20 & 0.14 & 0.18 & 0.12 & 0.17 & 0.13 & - & 24.2 & 231.2 \\
\hline 18 & 0.27 & 0.21 & 0.28 & 0.34 & 0.23 & 0.10 & 0.23 & 0.35 & 0.22 & 0.09 & 0.10 & 0.13 & 0.19 & 0.15 & 0.10 & 0.01 & 0.07 & - & 40.8 \\
\hline 19 & 0.40 & 0.35 & 0.34 & 0.43 & 0.37 & 0.28 & 0.43 & 0.48 & 0.38 & 0.23 & 0.27 & 0.31 & 0.37 & 0.27 & 0.28 & 0.16 & 0.20 & 0.13 & - \\
\hline
\end{tabular}


Table 7. Results of maximum-likelihood assignment tests from six Allegheny woodrat subpopulations. Within each column, numbers in boxes represent the total number of correct assignments for that study area. The total number of classifications of sample size is represented by $n, \mathrm{CCOS}$ and $\mathrm{CCO}$ are the number of correct classifications observed at the subpopulations and study areas respectively, and \%CCOS and \%CCO are the percentages of correct classifications at each level. Area abbreviations and locations are shown in Figure 3.

\begin{tabular}{c|cccc|ccc}
\hline \multicolumn{1}{l}{} & CR1 & CR2 & CR3 & CR4 & SH1 & SH2 & \\
\hline CR1 & 49 & 8 & 1 & 1 & 0 & 0 & \\
CR2 & 14 & 45 & 1 & 1 & 0 & 1 & \\
CR3 & 1 & 2 & 10 & 0 & 0 & 0 & \\
CR4 & 0 & 1 & 0 & 15 & 0 & 1 & \\
SH1 & 0 & 1 & 0 & 0 & 36 & 0 & \\
SH2 & 0 & 1 & 0 & 0 & 0 & 6 & Total \\
$n$ & 64 & 58 & 12 & 17 & 36 & 8 & 195 \\
CCOS & 49 & 45 & 10 & 15 & 36 & 6 & 161 \\
\%CCS & 76.6 & 77.6 & 83.3 & 88.2 & 100 & 75.0 & 82.6 \\
CCOP & 64 & 56 & 12 & 17 & 36 & 6 & 191 \\
\%CCP & 100 & 96.6 & 100 & 100 & 100 & 75.0 & 97.9 \\
\hline
\end{tabular}




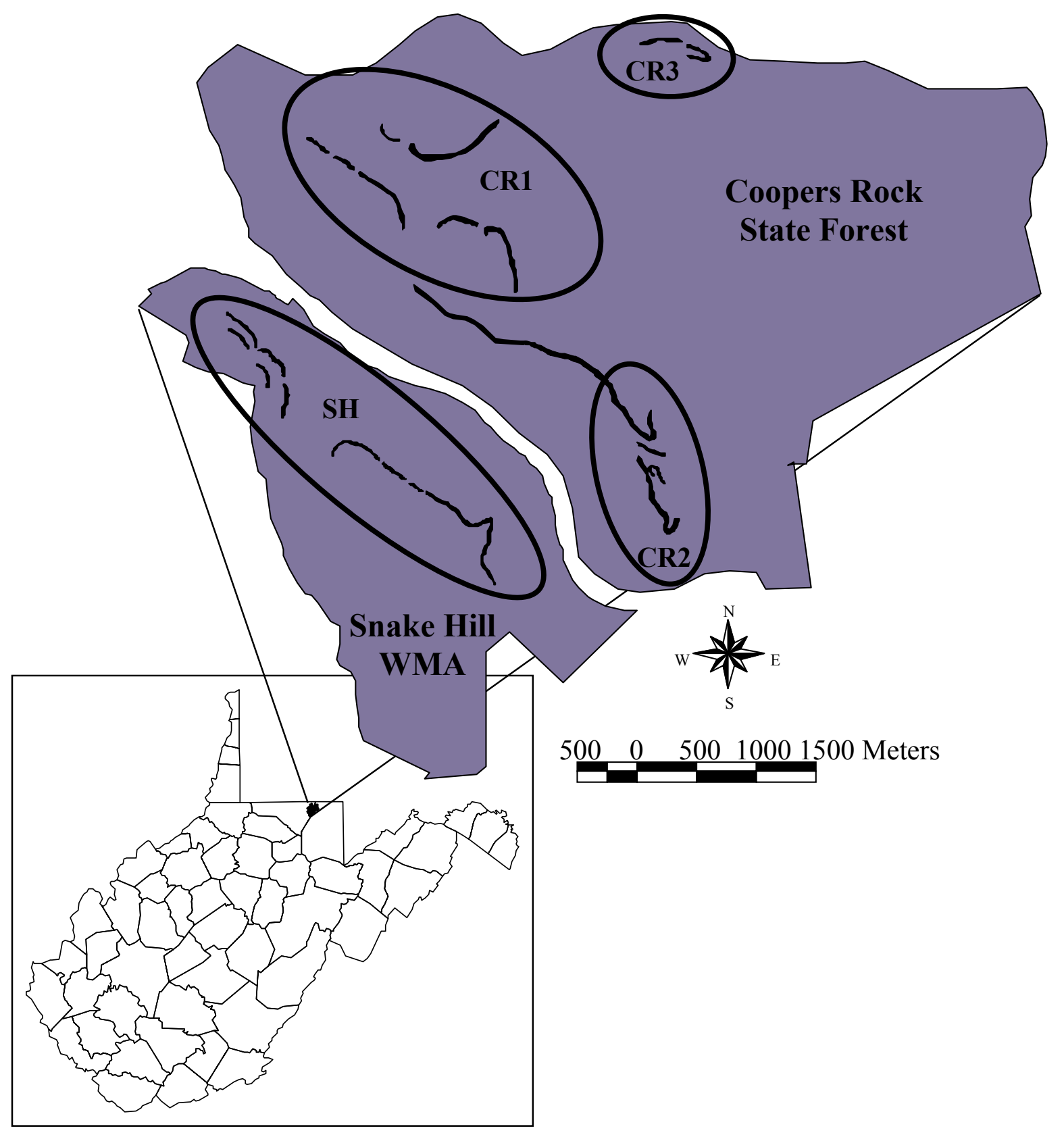

Figure 1. Study populations, Coopers Rock State Forest and Snake Hill Wildlife Management Area, and corresponding outcrops grouped into subpopulations based on neighbor-joining cluster analysis and geographic proximity of colonies (Castleberry et al. 2002). 


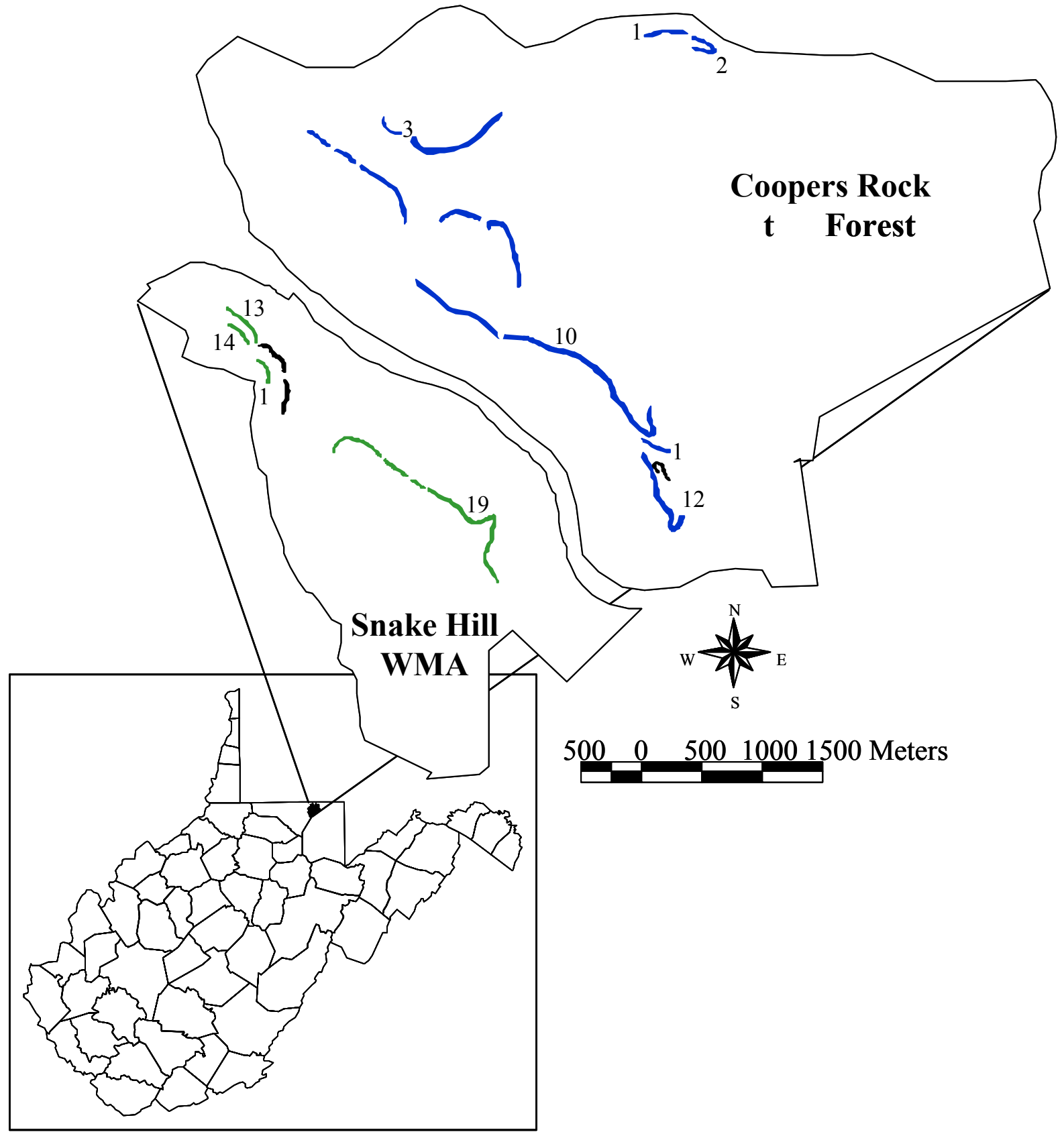

Figure 2. Study populations, Coopers Rock State Forest and Snake Hill Wildlife Management Area, and individual outcrops sampled for genetic analysis (\#3 includes 2 outcrops because only one animal was captured at the smaller outcrop). 


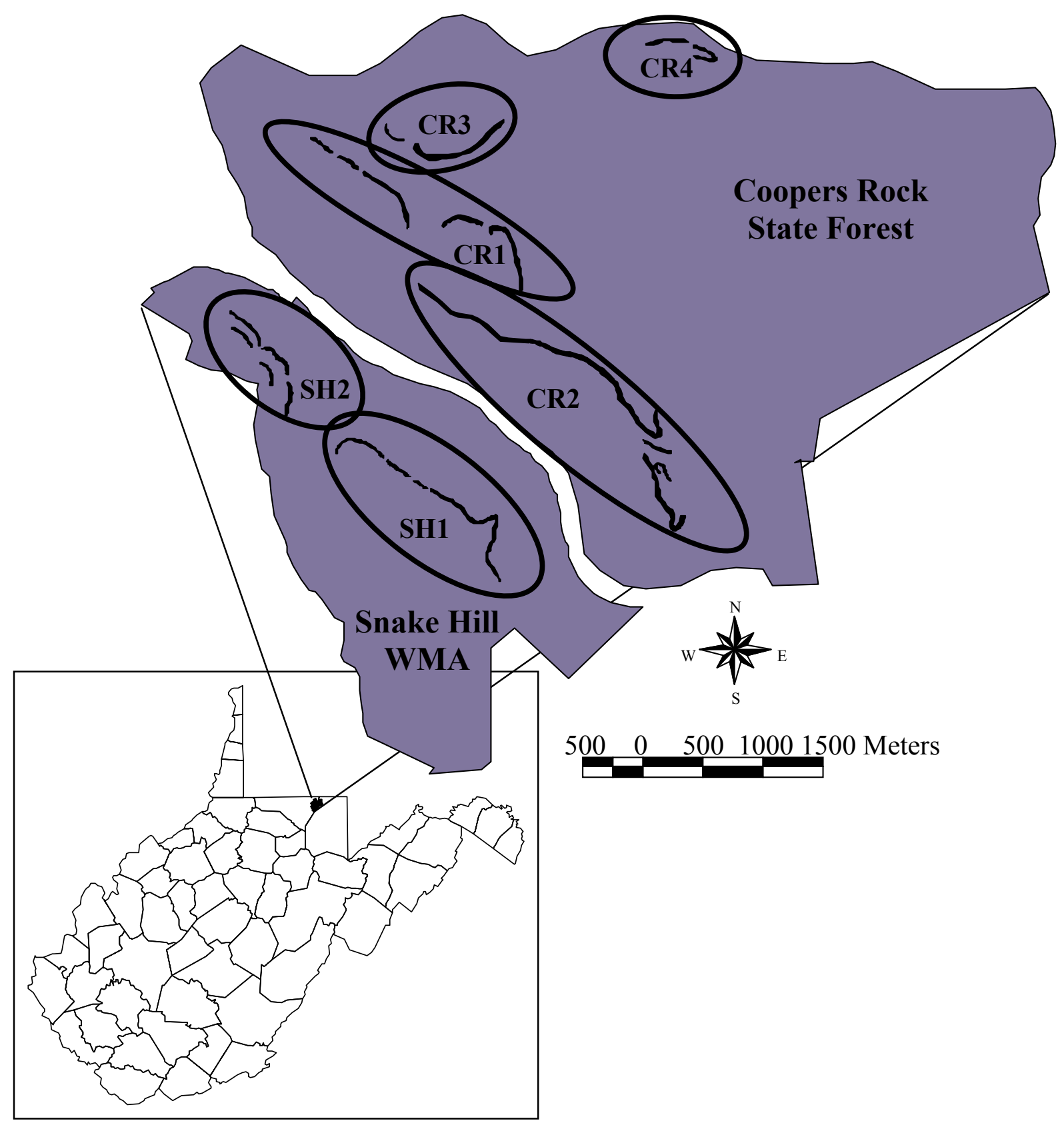

Figure 3. Study populations, Coopers Rock State Forest and Snake Hill Wildlife Management Area, and corresponding outcrops grouped into subpopulations based on linear topography of the outcrops and trapping records of recaptured individuals. 


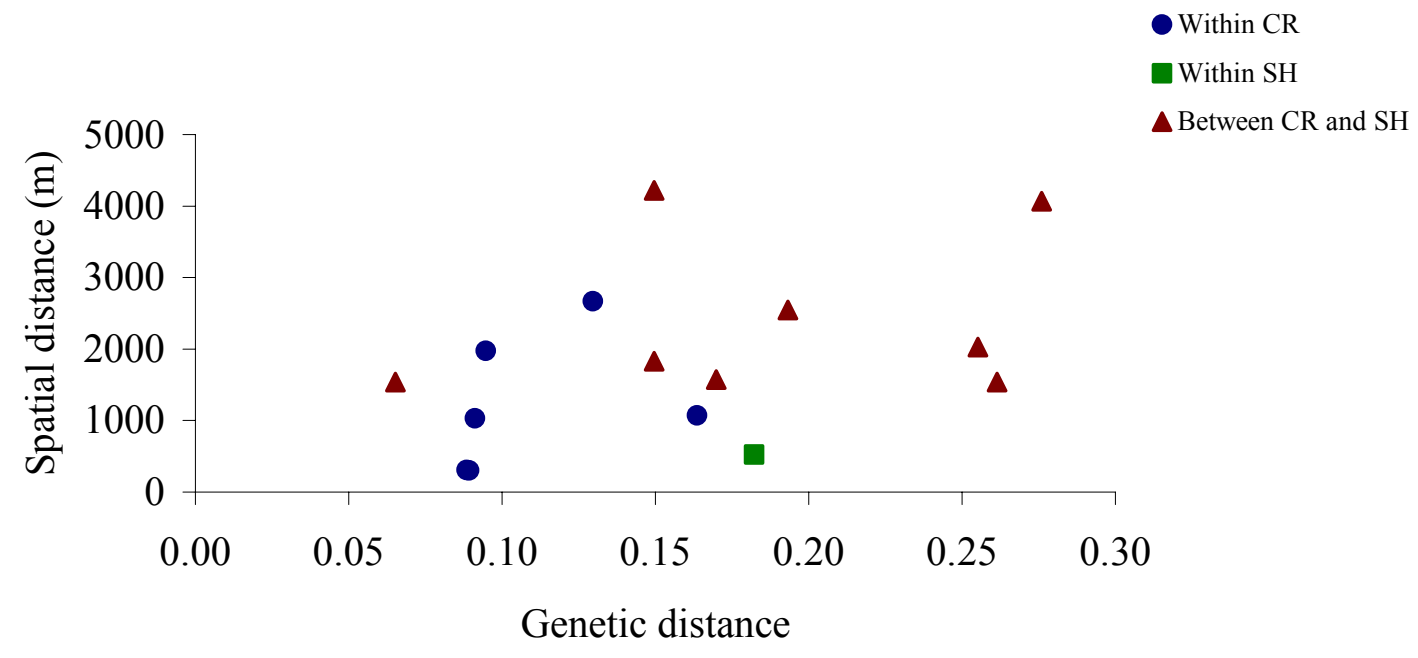

Figure 4. Relationship between pairwise comparisons of genetic and spatial distance for six Allegheny woodrat subpopulations $(r=0.43 ; P=0.063)$.

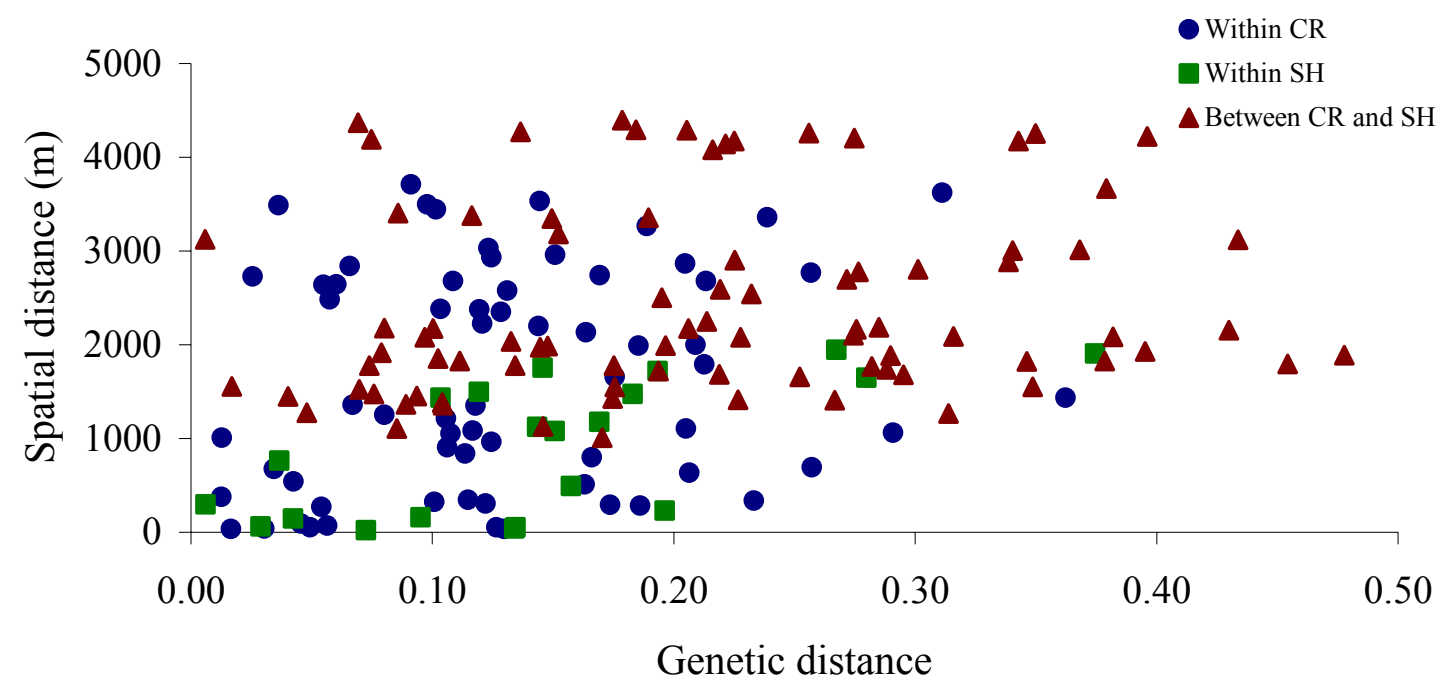

Figure 5. Relationship between pairwise comparisons of genetic and spatial distance for nineteen Allegheny woodrat assemblages $(r=0.30 ; P=0.003)$. 


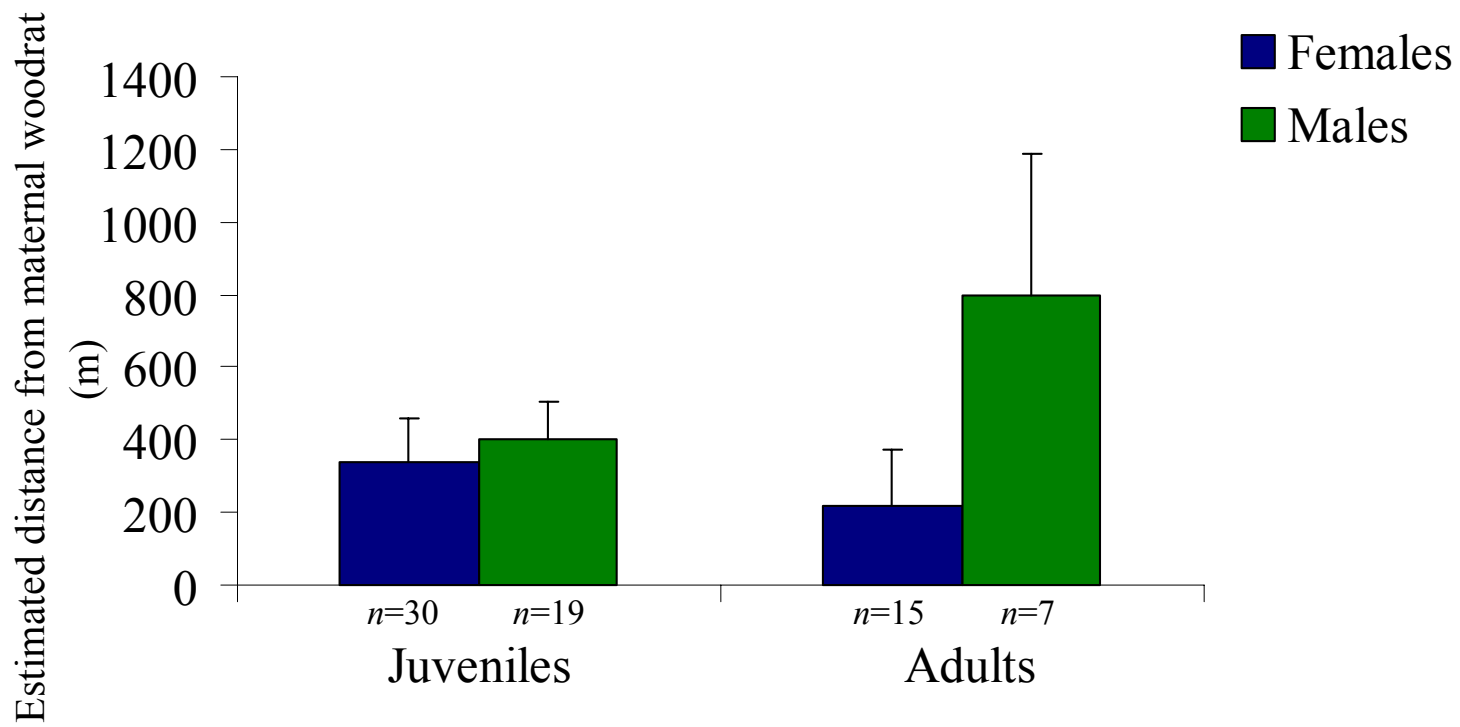

Figure 6. Estimated distance from maternal woodrat $(\mathrm{m})$ to female and male offspring for individuals captured as juveniles and those recaptured as adults.

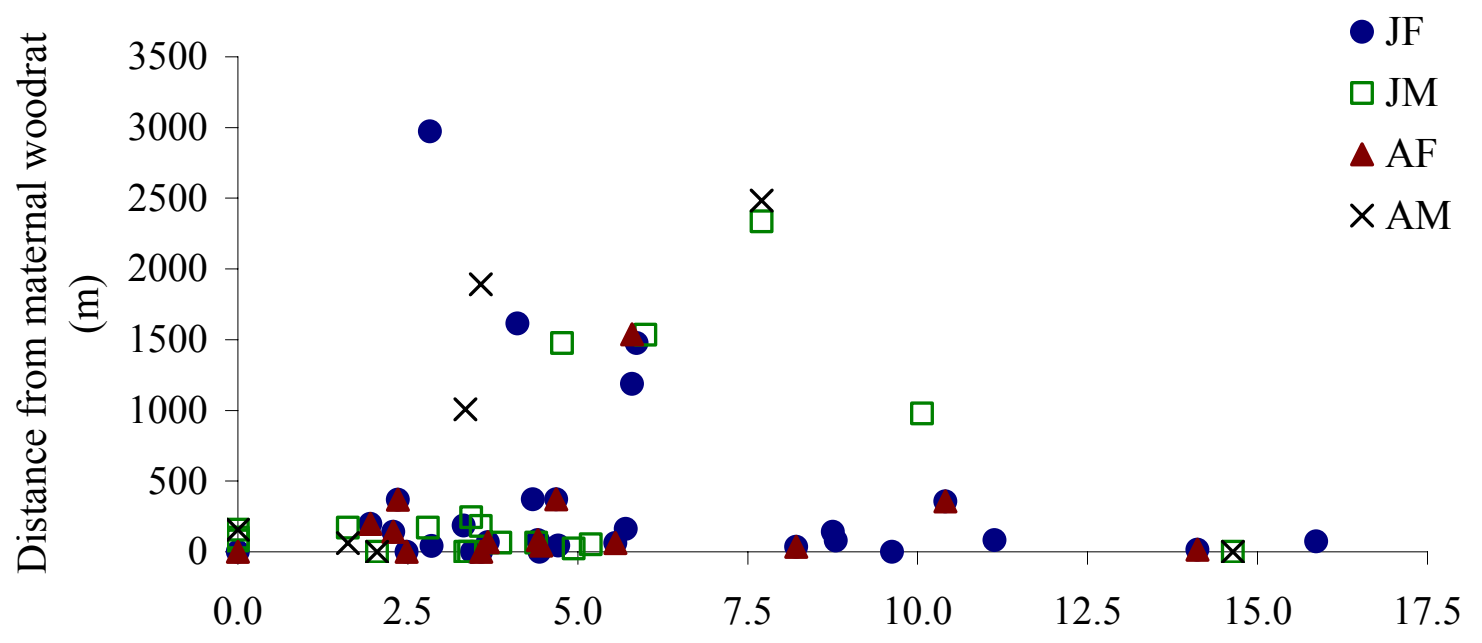

Figure 7. Estimated distance $(\mathrm{m})$ between maternal woodrat and likelihood of maternal relatedness 


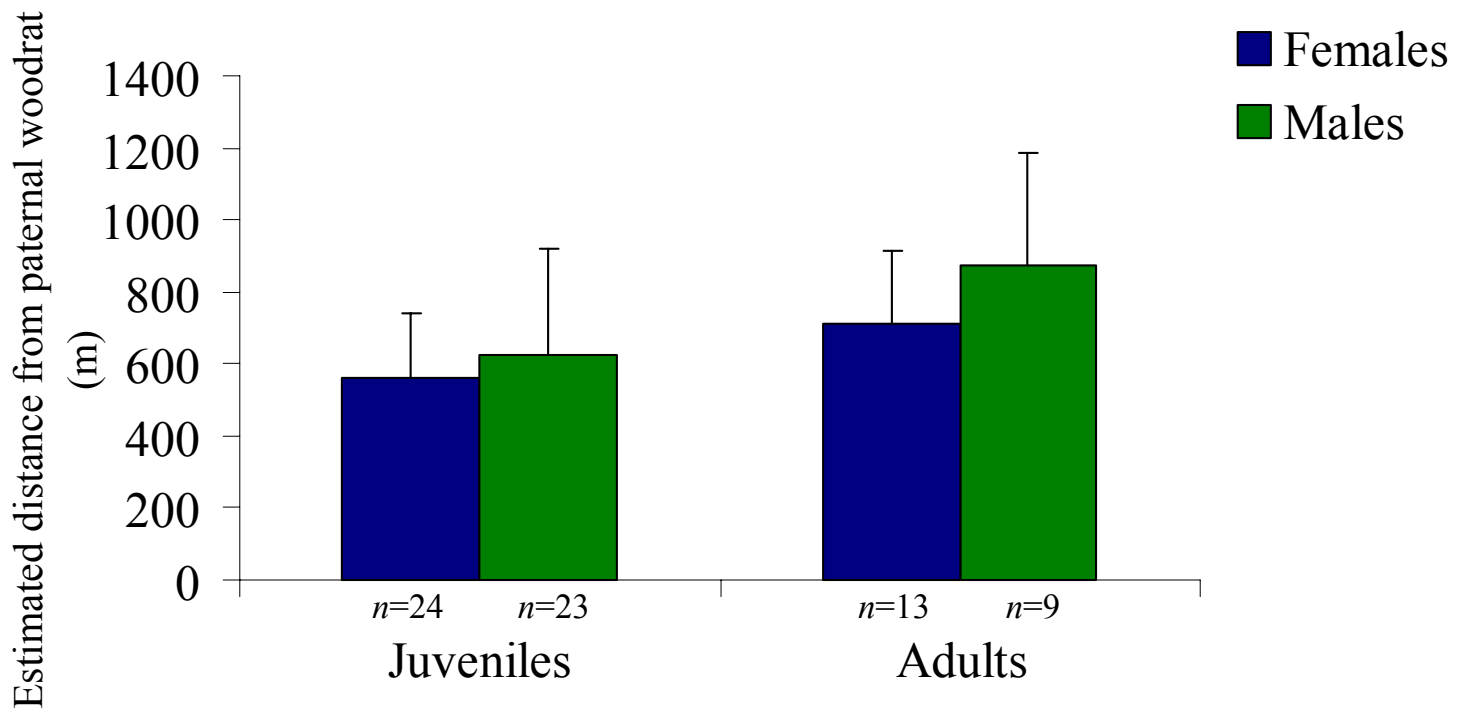

Figure 8. Estimated distance from paternal woodrat $(\mathrm{m})$ to female and male offspring for individuals captured as juveniles and those recaptured as adults.

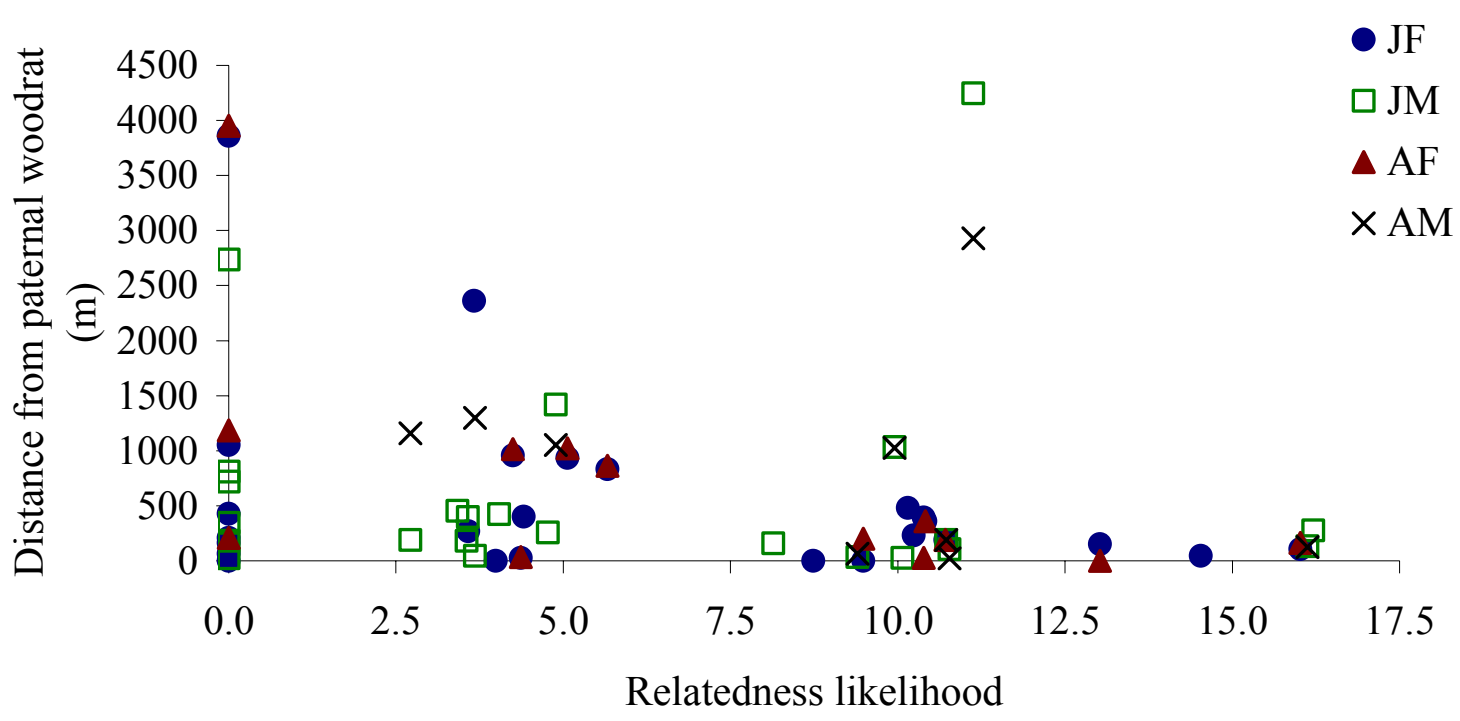

Figure 9. Estimated distance $(\mathrm{m})$ between paternal woodrat and likelihood of paternal relatedness 
Appendix B. Allele frequencies listed by fragment length of nine microsatellite loci examined in Allegheny woodrat populations breeding in northcentral West Virginia, 1999-2002.

\begin{tabular}{|c|c|c|c|c|c|c|c|c|c|}
\hline \multirow[b]{2}{*}{ Locus/allele } & \multicolumn{5}{|c|}{ Coopers Rock State Forest } & \multicolumn{3}{|c|}{$\begin{array}{l}\text { Snake Hill Wildlife } \\
\text { Management Area }\end{array}$} & \multirow[b]{2}{*}{ Overall } \\
\hline & CR1 & $\mathrm{CR} 2$ & CR3 & CR4 & Total & SH1 & $\mathrm{SH} 2$ & Total & \\
\hline \multicolumn{10}{|l|}{ Nma01 } \\
\hline 313 & 0.016 & 0.027 & 0.000 & 0.000 & 0.017 & 0.028 & 0.000 & 0.023 & 0.018 \\
\hline 315 & 0.047 & 0.116 & 0.250 & 0.206 & 0.109 & 0.000 & 0.125 & 0.023 & 0.090 \\
\hline 317 & 0.102 & 0.152 & 0.042 & 0.000 & 0.103 & 0.028 & 0.250 & 0.068 & 0.095 \\
\hline 319 & 0.359 & 0.205 & 0.333 & 0.294 & 0.291 & 0.833 & 0.250 & 0.727 & 0.390 \\
\hline 321 & 0.023 & 0.170 & 0.042 & 0.000 & 0.076 & 0.000 & 0.312 & 0.057 & 0.072 \\
\hline 323 & 0.453 & 0.330 & 0.333 & 0.500 & 0.404 & 0.111 & 0.062 & 0.102 & 0.336 \\
\hline $\mathrm{N}$ & 64 & 56 & 12 & 17 & 151 & 36 & 8 & 44 & 195 \\
\hline \multicolumn{10}{|l|}{ Nma04 } \\
\hline 151 & 0.367 & 0.114 & 0.333 & 0.147 & 0.243 & 0.069 & 0.062 & 0.068 & 0.204 \\
\hline 153 & 0.062 & 0.254 & 0.333 & 0.059 & 0.155 & 0.431 & 0.438 & 0.432 & 0.217 \\
\hline 155 & 0.039 & 0.105 & 0.000 & 0.147 & 0.076 & 0.250 & 0.062 & 0.219 & 0.107 \\
\hline 157 & 0.109 & 0.219 & 0.042 & 0.588 & 0.197 & 0.111 & 0.375 & 0.159 & 0.189 \\
\hline 159 & 0.422 & 0.289 & 0.292 & 0.059 & 0.322 & 0.097 & 0.000 & 0.080 & 0.268 \\
\hline 161 & 0.000 & 0.018 & 0.000 & 0.000 & 0.007 & 0.028 & 0.000 & 0.023 & 0.010 \\
\hline 163 & 0.000 & 0.000 & 0.000 & 0.000 & 0.000 & 0.014 & 0.062 & 0.023 & 0.005 \\
\hline $\mathrm{N}$ & 64 & 57 & 12 & 17 & 152 & 36 & 8 & 44 & 196 \\
\hline \multicolumn{10}{|l|}{ Nma05 } \\
\hline 227 & 0.897 & 0.614 & 1.000 & 1.000 & 0.811 & 0.833 & 0.643 & 0.802 & 0.809 \\
\hline 231 & 0.103 & 0.386 & 0.000 & 0.000 & 0.189 & 0.167 & 0.357 & 0.198 & 0.191 \\
\hline $\mathrm{N}$ & 63 & 57 & 12 & 17 & 151 & 36 & 7 & 43 & 194 \\
\hline \multicolumn{10}{|l|}{ Nma08 } \\
\hline 120 & 0.195 & 0.431 & 0.583 & 0.088 & 0.301 & 0.042 & 0.125 & 0.057 & 0.246 \\
\hline 122 & 0.000 & 0.000 & 0.000 & 0.382 & 0.046 & 0.111 & 0.000 & 0.091 & 0.056 \\
\hline 124 & 0.477 & 0.310 & 0.250 & 0.147 & 0.356 & 0.500 & 0.562 & 0.511 & 0.391 \\
\hline 126 & 0.195 & 0.095 & 0.000 & 0.059 & 0.127 & 0.000 & 0.125 & 0.023 & 0.104 \\
\hline 130 & 0.078 & 0.112 & 0.000 & 0.235 & 0.105 & 0.264 & 0.125 & 0.239 & 0.135 \\
\hline 132 & 0.055 & 0.052 & 0.167 & 0.088 & 0.065 & 0.083 & 0.062 & 0.080 & 0.069 \\
\hline $\mathrm{N}$ & 64 & 58 & 12 & 17 & 153 & 36 & 8 & 44 & 197 \\
\hline \multicolumn{10}{|l|}{ Nma10 } \\
\hline 194 & 0.000 & 0.000 & 0.000 & 0.000 & 0.000 & 0.014 & 0.000 & 0.011 & 0.003 \\
\hline 196 & 0.048 & 0.060 & 0.292 & 0.188 & 0.086 & 0.403 & 0.188 & 0.364 & 0.149 \\
\hline 198 & 0.270 & 0.103 & 0.000 & 0.250 & 0.182 & 0.069 & 0.062 & 0.068 & 0.156 \\
\hline 200 & 0.000 & 0.009 & 0.000 & 0.000 & 0.003 & 0.222 & 0.000 & 0.182 & 0.044 \\
\hline 202 & 0.000 & 0.000 & 0.000 & 0.000 & 0.000 & 0.111 & 0.188 & 0.123 & 0.028 \\
\hline 206 & 0.056 & 0.121 & 0.000 & 0.125 & 0.089 & 0.000 & 0.062 & 0.011 & 0.072 \\
\hline 208 & 0.016 & 0.086 & 0.208 & 0.031 & 0.060 & 0.000 & 0.000 & 0.000 & 0.046 \\
\hline
\end{tabular}


Appendix B cont.

\begin{tabular}{lrrrrrrrrr}
\hline 210 & 0.262 & 0.043 & 0.000 & 0.094 & 0.136 & 0.028 & 0.125 & 0.043 & 0.115 \\
212 & 0.000 & 0.000 & 0.000 & 0.062 & 0.007 & 0.000 & 0.000 & 0.000 & 0.005 \\
218 & 0.175 & 0.440 & 0.083 & 0.156 & 0.268 & 0.111 & 0.375 & 0.159 & 0.244 \\
220 & 0.024 & 0.034 & 0.250 & 0.000 & 0.043 & 0.014 & 0.000 & 0.011 & 0.036 \\
222 & 0.024 & 0.026 & 0.000 & 0.031 & 0.023 & 0.000 & 0.000 & 0.000 & 0.018 \\
224 & 0.000 & 0.000 & 0.000 & 0.000 & 0.000 & 0.028 & 0.000 & 0.023 & 0.005 \\
226 & 0.016 & 0.000 & 0.000 & 0.000 & 0.007 & 0.000 & 0.000 & 0.000 & 0.005 \\
228 & 0.111 & 0.078 & 0.167 & 0.032 & 0.096 & 0.000 & 0.000 & 0.000 & 0.074 \\
$\mathrm{~N}$ & 63 & 58 & 12 & 16 & 151 & 36 & 8 & 44 & 195
\end{tabular}

\section{Nma11}

$\begin{array}{lrrrrrrrrr}132 & 0.008 & 0.034 & 0.000 & 0.235 & 0.046 & 0.000 & 0.000 & 0.000 & 0.036 \\ 150 & 0.000 & 0.000 & 0.000 & 0.029 & 0.003 & 0.000 & 0.000 & 0.000 & 0.003 \\ 152 & 0.023 & 0.078 & 0.000 & 0.118 & 0.053 & 0.029 & 0.000 & 0.024 & 0.046 \\ 154 & 0.000 & 0.017 & 0.000 & 0.000 & 0.007 & 0.057 & 0.214 & 0.083 & 0.023 \\ 156 & 0.000 & 0.000 & 0.000 & 0.000 & 0.000 & 0.129 & 0.071 & 0.119 & 0.026 \\ 158 & 0.609 & 0.293 & 0.636 & 0.412 & 0.467 & 0.429 & 0.357 & 0.417 & 0.456 \\ 160 & 0.297 & 0.457 & 0.091 & 0.176 & 0.326 & 0.300 & 0.071 & 0.262 & 0.312 \\ 162 & 0.062 & 0.121 & 0.273 & 0.029 & 0.099 & 0.057 & 0.143 & 0.071 & 0.093 \\ 164 & 0.000 & 0.000 & 0.000 & 0.000 & 0.000 & 0.000 & 0.143 & 0.024 & 0.005 \\ \mathrm{~N} & 64 & 58 & 11 & 17 & 152 & 35 & 7 & 42 & 194\end{array}$

Nma12

\begin{tabular}{lrrrrrrrrr}
116 & 0.984 & 0.802 & 1.000 & 1.000 & 0.918 & 0.486 & 1.000 & 0.580 & 0.843 \\
119 & 0.016 & 0.198 & 0.000 & 0.000 & 0.082 & 0.514 & 0.000 & 0.420 & 0.157 \\
$\mathrm{~N}$ & 64 & 58 & 12 & 17 & 153 & 36 & 8 & 44 & 197 \\
Nma14 & & & & & & & & & \\
145 & 0.211 & 0.272 & 0.417 & 0.062 & 0.232 & 0.143 & 0.000 & 0.116 & 0.206 \\
147 & 0.078 & 0.044 & 0.208 & 0.219 & 0.093 & 0.057 & 0.062 & 0.058 & 0.085 \\
149 & 0.367 & 0.386 & 0.375 & 0.250 & 0.364 & 0.314 & 0.438 & 0.337 & 0.358 \\
151 & 0.328 & 0.175 & 0.000 & 0.469 & 0.258 & 0.071 & 0.438 & 0.140 & 0.232 \\
153 & 0.016 & 0.123 & 0.000 & 0.000 & 0.053 & 0.414 & 0.062 & 0.349 & 0.119 \\
$\mathrm{~N}$ & 64 & 57 & 12 & 16 & 151 & 35 & 8 & 43 & 194 \\
$\mathbf{N m a 1 5}$ & & & & & & & & & \\
118 & 0.016 & 0.096 & 0.208 & 0.118 & 0.073 & 0.000 & 0.000 & 0.000 & 0.056 \\
120 & 0.032 & 0.009 & 0.000 & 0.000 & 0.017 & 0.042 & 0.000 & 0.034 & 0.021 \\
122 & 0.127 & 0.298 & 0.208 & 0.000 & 0.182 & 0.028 & 0.062 & 0.034 & 0.149 \\
124 & 0.000 & 0.061 & 0.000 & 0.000 & 0.023 & 0.611 & 0.062 & 0.511 & 0.133 \\
126 & 0.746 & 0.377 & 0.583 & 0.735 & 0.593 & 0.139 & 0.250 & 0.159 & 0.495 \\
128 & 0.000 & 0.009 & 0.000 & 0.059 & 0.013 & 0.028 & 0.438 & 0.102 & 0.033 \\
130 & 0.079 & 0.149 & 0.000 & 0.088 & 0.099 & 0.139 & 0.188 & 0.148 & 0.110 \\
132 & 0.000 & 0.000 & 0.000 & 0.000 & 0.000 & 0.014 & 0.000 & 0.011 & 0.003 \\
$\mathrm{~N}$ & 63 & 57 & 12 & 17 & 151 & 36 & 8 & 44 & 195 \\
\hline
\end{tabular}

